Supporting Information for:

\title{
Iodine/Manganese Dual Catalysis for Oxidative Dehydrogenation Coupling of Amines with Thiols
}

\author{
Shengping Liu, ${ }^{\text {a,b }}$ Zaojuan Qi, ${ }^{\mathrm{b}}$ Zhang Zhang, ${ }^{* \mathrm{a}}$ and Bo Qian*b \\ ${ }^{a}$ Key Laboratory of Eco-Environment-Related Polymer Materials Ministry of Education, College \\ of Chemistry and Chemical Engineering, Northwest Normal University, Lanzhou, Gansu 730070, \\ China \\ ${ }^{\mathrm{b}}$ State Key Laboratory for Oxo Synthesis and Selective Oxidation, Lanzhou Institute of Chemical \\ Physics, Chinese Academy of Sciences, Lanzhou, 730000, P. R. China \\ E-mail: zhangz@nwnu.edu.cn, boqian@licp.cas.cn
}

\section{Contents}

1 General experimental details and materials.............................S2

2 Optimization of reaction conditions.......................................S3

3 General procedure for the oxidative dehydrogenation coupling reation........S6

4 Preliminary mechanistic studies........................................ 7

5 Synthetic application......................................................S16

6 Experimental characterization date for products..........................S18

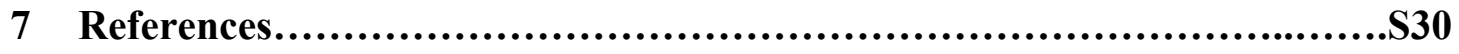

8 Copies for NMR of products..........................................S31 


\section{General experiment details and materials}

All non-aqueous reactions and manipulations were used by standard Schlenk techniques. All solvents before used were dried and degassed by standard methods and stored under nitrogen atmosphere. All reactions were monitored by TLC with silica gel-coated plates. NMR spectra were recorded on BRUKER Avance III (400 MHz) spectrometers. Chemical shifts were reported in parts per million (ppm) down field from tetramethylsilane (TMS) with the solvent resonance as the internal standard. Coupling constants (J) were reported in $\mathrm{Hz}$ and refered to apparent peak multiplications. High resolution mass spectra (HRMS) were recorded on Bruker MicroTOF-QII mass instrument (ESI). Gas chromatograph/mass spectrometer (GC/MS) were recorded on Agilent 7890A/5975C system. Amines and thiols used here were known compounds and commercially available. 


\section{Optimization of reaction conditions}

Table S1. Screening of catalysts ${ }^{a}$

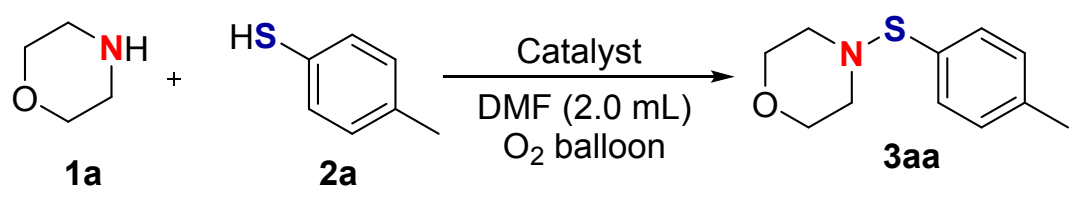

\begin{tabular}{|c|c|c|}
\hline Entry & Catalyst (mol \%) & Yield $(\%)^{b}$ \\
\hline 1 & $\mathrm{I}_{2}(10) / \mathrm{NBS}(10)$ & trace \\
\hline 2 & $\mathrm{I}_{2}(10) / \mathrm{PhI}(\mathrm{OAc})_{2}(10)$ & trace \\
\hline 3 & $\mathrm{I}_{2}(10) / \mathrm{DDQ}(10)$ & trace \\
\hline 4 & $\mathrm{I}_{2}(10) / \mathrm{CaO}(10)$ & trace \\
\hline 5 & $\mathrm{I}_{2}(10) / \mathrm{K}_{2} \mathrm{~S}_{2} \mathrm{O}_{8}(10)$ & 13 \\
\hline 6 & $\mathrm{I}_{2}(10) / \mathrm{Na}_{2} \mathrm{Cr}_{2} \mathrm{O}_{7}(10)$ & trace \\
\hline 7 & $\mathrm{I}_{2}(10) / \mathrm{NaIO}_{4}(10)$ & 42 \\
\hline 8 & $\mathrm{I}_{2}(10) / \mathrm{I}_{2} \mathrm{O}_{5}(10)$ & 54 \\
\hline 9 & $\mathrm{I}_{2}(10) / \mathrm{MnI}_{2}(10)$ & trace \\
\hline 10 & $\mathrm{I}_{2}(10) / \mathrm{Mn}(\mathrm{OAc})_{2}(10)$ & trace \\
\hline 11 & $\mathrm{I}_{2}(10) / \mathrm{Mn}(\mathrm{OAc})_{3}(10)$ & 22 \\
\hline 12 & $\mathrm{I}_{2}(10) / \mathrm{KMnO}_{4}(10)$ & 80 \\
\hline 13 & $\mathrm{KI}(10) / \mathrm{KMnO}_{4}(10)$ & 14 \\
\hline 14 & $\mathrm{NaI}(10) / \mathrm{KMnO}_{4}(10)$ & trace \\
\hline 15 & $\mathrm{LiI}(10) / \mathrm{KMnO}_{4}(10)$ & trace \\
\hline 16 & $\mathrm{NH}_{4} \mathrm{I}(10) / \mathrm{KMnO}_{4}(10)$ & 50 \\
\hline 17 & NIS (10)/KMnO 4 (10) & trace \\
\hline 18 & $\mathrm{I}_{2}(10)$ & trace \\
\hline 19 & $\mathrm{KMnO}_{4}(10)$ & trace \\
\hline 20 & KI (10) & trace \\
\hline 21 & $\mathrm{NH}_{4} \mathrm{I}(10)$ & trace \\
\hline 22 & NIS (10) & trace \\
\hline 23 & $\mathrm{NaIO}_{4}(10)$ & trace \\
\hline 24 & 1 & / \\
\hline 25 & $\mathrm{I}_{2}(10) / \mathrm{KMnO}_{4}(10)$ & $75^{c}$ \\
\hline
\end{tabular}

${ }^{a}$ Reaction conditions: $1 \mathrm{a}(0.5 \mathrm{mmol}, 1$ equiv), $\mathbf{2 a}(0.5 \mathrm{mmol}, 1$ equiv), catalyst (10 mol \%), DMF $(2.0 \mathrm{~mL})$ at $80^{\circ} \mathrm{C}$ for 12 hours, $\mathrm{O}_{2}$ balloon. ${ }^{b}$ Isolated yields. ${ }^{c}$ Under air atmosphere.

Table S2. Screening of solvent ${ }^{a}$ 


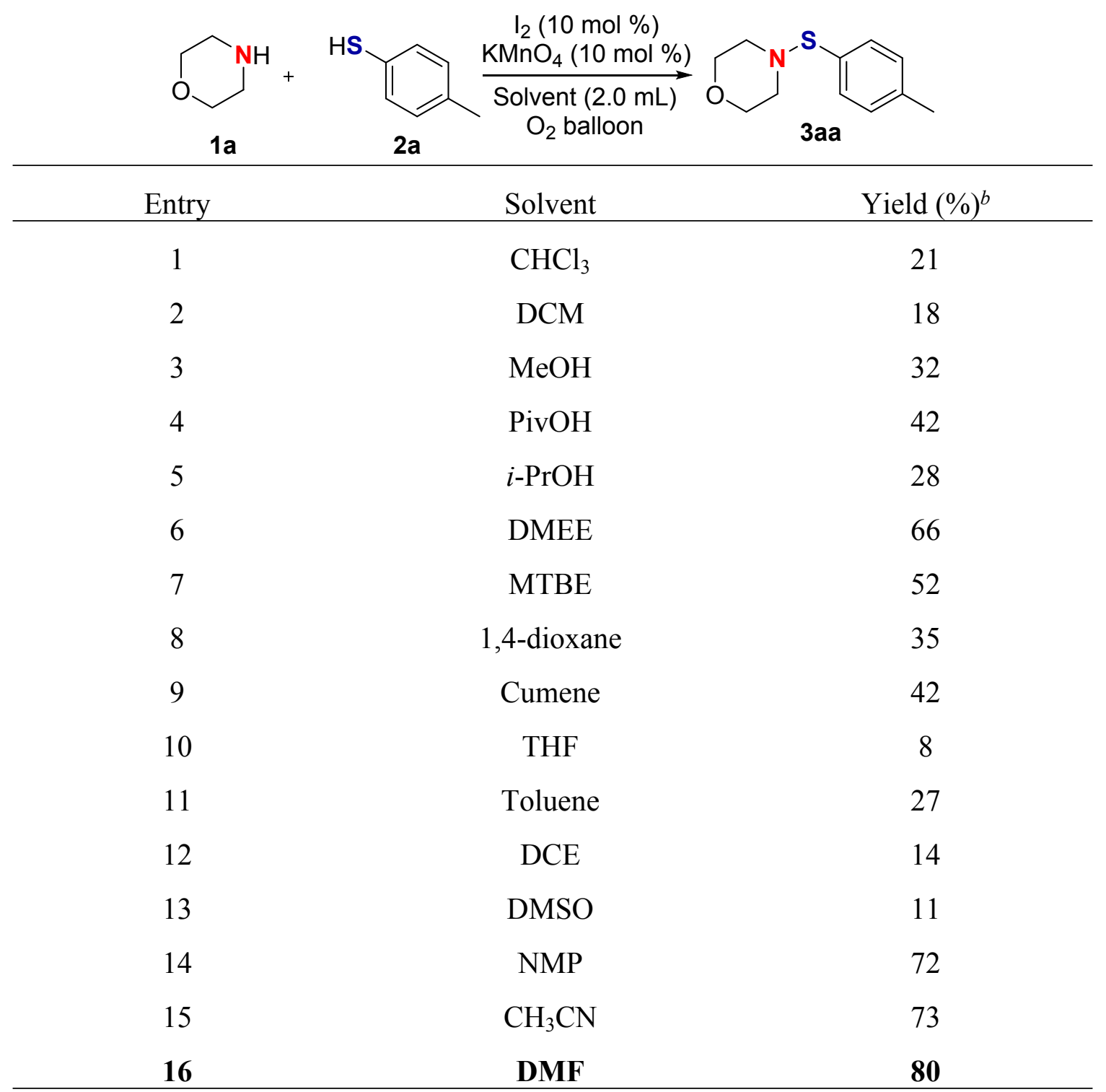

${ }^{a}$ Reaction conditions: 1a ( $0.5 \mathrm{mmol}, 1$ equiv), $\mathbf{2 a}\left(0.5 \mathrm{mmol}, 1\right.$ equiv), $\mathrm{I}_{2}(10 \mathrm{~mol} \%), \mathrm{KMnO}_{4}(10$ mol \%), Solvent $(2.0 \mathrm{~mL})$ at $80{ }^{\circ} \mathrm{C}$ for 12 hours, $\mathrm{O}_{2}$ balloon. ${ }^{b}$ Isolated yields.

Table S3. Screening of reaction time ${ }^{a}$

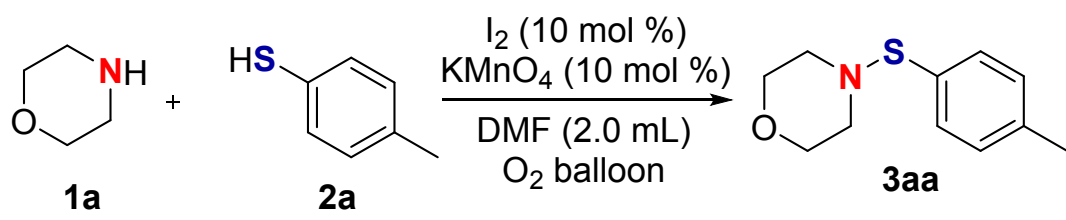

\begin{tabular}{ccc}
\hline Entry & Time $(\mathrm{h})$ & ${\text { Yield }(\%)^{b}}^{b}$ \\
\hline 1 & 6 & 43 \\
$\mathbf{2}$ & $\mathbf{1 2}$ & $\mathbf{8 0}$ \\
3 & 24 & 81 \\
\hline
\end{tabular}

${ }^{a}$ Reaction conditions: 1a ( 0.5 mmol, 1 equiv), $\mathbf{2 a}\left(0.5 \mathrm{mmol}, 1\right.$ equiv), $\mathrm{I}_{2}(10 \mathrm{~mol} \%), \mathrm{KMnO}_{4}(10$ mol \%), DMF $(2.0 \mathrm{~mL})$ at $80^{\circ} \mathrm{C}, \mathrm{O}_{2}$ balloon. ${ }^{b}$ Isolated yields. 
Table S4. Screening of temperature ${ }^{a}$<smiles>C1COCCN1</smiles>

1a<smiles>Cc1ccc(S)cc1</smiles>

2a
$\mathrm{I}_{2}(10 \mathrm{~mol} \%)$ $\mathrm{KMnO}_{4}(10 \mathrm{~mol} \%)$ DMF $(2.0 \mathrm{~mL})$ $\mathrm{O}_{2}$ balloon<smiles>Cc1ccc(SN2CCOCC2)cc1</smiles>
3aa

\begin{tabular}{ccc}
\hline Entry & Temp. $\left({ }^{\circ} \mathrm{C}\right)$ & Yield $(\%)^{b}$ \\
\hline 1 & 60 & 70 \\
$\mathbf{2}$ & $\mathbf{8 0}$ & $\mathbf{8 0}$ \\
3 & 100 & 78 \\
4 & 120 & 75 \\
\hline
\end{tabular}

${ }^{a}$ Reaction conditions: $\mathbf{1 a}\left(0.5 \mathrm{mmol}, 1\right.$ equiv), $\mathbf{2 a}\left(0.5 \mathrm{mmol}, 1\right.$ equiv), $\mathrm{I}_{2}(10 \mathrm{~mol} \%), \mathrm{KMnO}_{4}(10$ $\mathrm{mol} \%)$, DMF (2.0 mL) for 12 hours, $\mathrm{O}_{2}$ balloon. ${ }^{b}$ Isolated yields. 


\section{General procedure for the oxidative dehydrogenation coupling}

reation

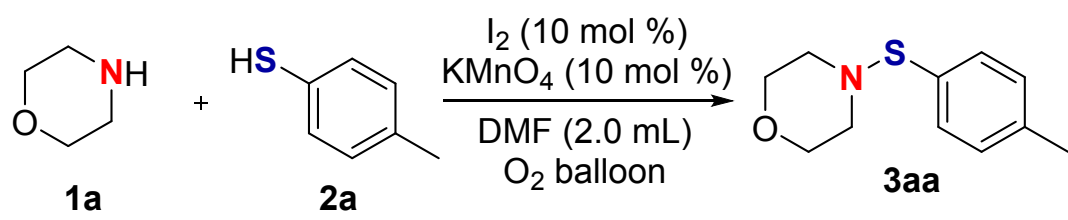

$\mathrm{I}_{2}(12.7 \mathrm{mg}, 0.05 \mathrm{mmol}), \mathrm{KMnO}_{4}(7.9 \mathrm{mg}, 0.05 \mathrm{mmol})$, morpholine $\mathbf{1 a}(40.0 \mu \mathrm{L}$, $0.5 \mathrm{mmol})$, 4-methylbenzenethiol $2 \mathrm{a}(62.0 \mathrm{mg}, 0.5 \mathrm{mmol})$ and DMF $(2.0 \mathrm{~mL})$ were added into the reaction tube under air. The mixture was stirred at $80{ }^{\circ} \mathrm{C}$ for 12 hours with an oxygen balloon. After cooling to room temperature, the reaction was quenched by $10 \mathrm{~mL}$ of $\mathrm{NaCl}$ saturated solution, The aqueous phase extracted with ethyl acetate $(3 \times 20 \mathrm{~mL})$ and the combined organic phases dried with $\mathrm{Na}_{2} \mathrm{SO}_{4}$. The solvent was removed under reduced pressure. Then the reaction mixture was purified by flash column chromatography on silica gel and eluted with ethyl acetate/hexane (1/200 1/50, $3 \sim 5$ drops of $\mathrm{Et}_{3} \mathrm{~N}$ in $200 \mathrm{~mL}$ of eluent) to give the desired product 3aa. 


\section{Preliminary mechanistic studies}

(1)

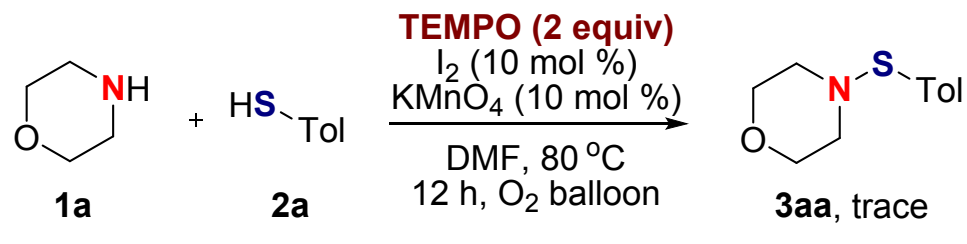

$\mathrm{I}_{2}(12.7 \mathrm{mg}, 0.05 \mathrm{mmol}), \mathrm{KMnO}_{4}(7.9 \mathrm{mg}, 0.05 \mathrm{mmol})$, morpholine 1a $(40.0 \mu \mathrm{L}$, $0.5 \mathrm{mmol})$, 4-methylbenzenethiol $\mathbf{2 a}(62.0 \mathrm{mg}, 0.5 \mathrm{mmol})$, TEMPO (156.0 mg, 1.0 mmol) and DMF $(2.0 \mathrm{~mL})$ were added into the reaction tube under air. The mixture was stirred at $80{ }^{\circ} \mathrm{C}$ for 12 hours with an oxygen balloon. After cooling to room temperature, the reaction was quenched by $10 \mathrm{~mL}$ of $\mathrm{NaCl}$ saturated solution, The aqueous phase extracted with ethyl acetate $(3 \times 20 \mathrm{~mL})$ and the combined organic phases dried with $\mathrm{Na}_{2} \mathrm{SO}_{4}$. Then the reaction mixture was detected by GC/MS, giving trace amount of product 3aa.

The results suggested that radical process might be involved into the oxidative dehydrogenation cross-coupling of amines with thiols.<smiles>C1COCCN1</smiles>

1a

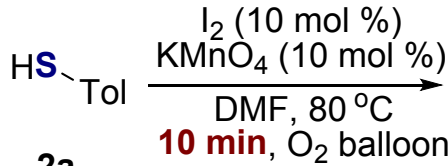
$2 a$

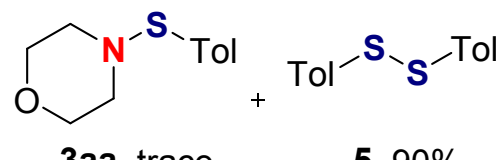

3aa, trace
$5,90 \%$

$\mathrm{I}_{2}(12.7 \mathrm{mg}, 0.05 \mathrm{mmol}), \mathrm{KMnO}_{4}(7.9 \mathrm{mg}, 0.05 \mathrm{mmol})$, morpholine $1 \mathrm{a}(40.0 \mu \mathrm{L}$, $0.5 \mathrm{mmol})$, 4-methylbenzenethiol $2 \mathrm{a}(62.0 \mathrm{mg}, 0.5 \mathrm{mmol})$ and DMF (2.0 $\mathrm{mL})$ were added into the reaction tube under air. The mixture was stirred at $80{ }^{\circ} \mathrm{C}$ for ten minutes with an oxygen balloon. After cooling to room temperature, the reaction was quenched by $10 \mathrm{~mL}$ of $\mathrm{NaCl}$ saturated solution, The aqueous phase extracted with ethyl acetate $(3 \times 20 \mathrm{~mL})$ and the combined organic phases dried with $\mathrm{Na}_{2} \mathrm{SO}_{4}$. The solvent was removed under reduced pressure. Then the reaction mixture was purified by flash column chromatography on silica gel and eluted with ethyl acetate/hexane (1/200) to give trace amount of desired product 3aa and 90\% yield of disulfide $\mathbf{5}$ (55.4 mg, white solid). 


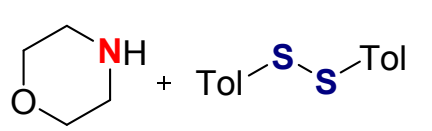

1a
5

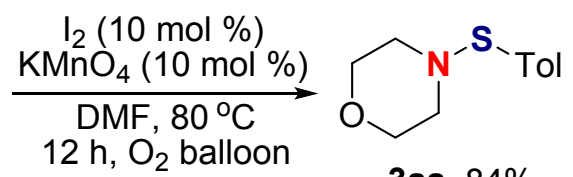

3aa, $84 \%$

$\mathrm{I}_{2}(12.7 \mathrm{mg}, 0.05 \mathrm{mmol}), \mathrm{KMnO}_{4}(7.9 \mathrm{mg}, 0.05 \mathrm{mmol})$, morpholine 1a $(40.0 \mu \mathrm{L}$, $0.5 \mathrm{mmol})$, disulfide $5(61.5 \mathrm{mg}, 0.25 \mathrm{mmol})$ and DMF $(2.0 \mathrm{~mL})$ were added into the reaction tube under air. The mixture was stirred at $80^{\circ} \mathrm{C}$ for 12 hours with an oxygen balloon. After cooling to room temperature, the reaction was quenched by $10 \mathrm{~mL}$ of $\mathrm{NaCl}$ saturated solution, The aqueous phase extracted with ethyl acetate $(3 \times 20 \mathrm{~mL})$ and the combined organic phases dried with $\mathrm{Na}_{2} \mathrm{SO}_{4}$. The solvent was removed under reduced pressure. Then the reaction mixture was purified by flash column chromatography on silica gel and eluted with ethyl acetate/hexane $(1 / 200 \sim 1 / 50,3 \sim 5$ drops of $\mathrm{Et}_{3} \mathrm{~N}$ in $200 \mathrm{~mL}$ of eluent) to give the desired product 3aa $(87.4 \mathrm{mg}, 84 \%$ yield).

Schemes (2) and (3) demonstrated that disulfide might be a key intermediate in the transformation and the generation of disulfide is a rapid step.

(4)<smiles>C1CN(N2CCOCC2)CCO1</smiles><smiles>[PbH]=[Po]</smiles>

2a

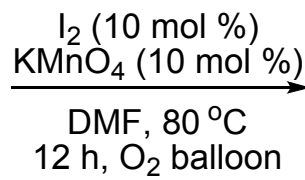<smiles></smiles>

$\mathrm{I}_{2}(12.7 \mathrm{mg}, 0.05 \mathrm{mmol}), \mathrm{KMnO}_{4}(7.9 \mathrm{mg}, 0.05 \mathrm{mmol})$, diamine 6 (43.0 mg, 0.25 mmol), 4-methylbenzenethiol 2a (62.0 mg, $0.5 \mathrm{mmol})$ and DMF $(2.0 \mathrm{~mL})$ were added into the reaction tube under air. The mixture was stirred at $80{ }^{\circ} \mathrm{C}$ for 12 hours with an oxygen balloon. After cooling to room temperature, the product 3aa could not be detected by TLC. The reaction was quenched by $10 \mathrm{~mL}$ of $\mathrm{NaCl}$ saturated solution. The aqueous phase extracted with ethyl acetate $(3 \times 20 \mathrm{~mL})$ and the combined organic phases dried with $\mathrm{Na}_{2} \mathrm{SO}_{4}$. The solvent was removed under reduced pressure. Then the reaction mixture was purified by flash column chromatography on silica gel and eluted with ethyl acetate/hexane (1/200) to give the disulfide 5 (45.7 $\mathrm{mg}, 74 \%$ yield).

The results suggested that diamine was not an intermidiates in this process.

\section{Method for the synthesis of diamine 6:}




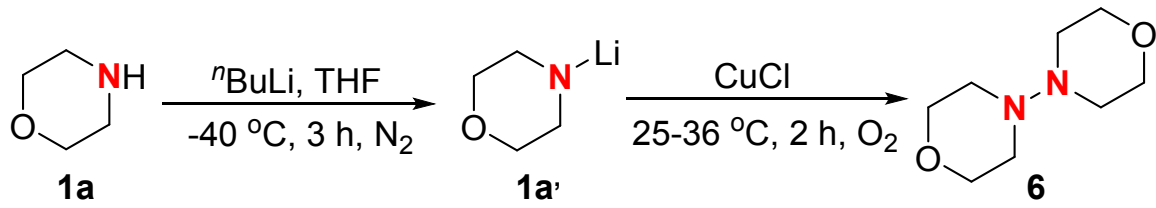

Under nitrogen atmosphere, taking the reaction tube in a low temperature reactor, then morpholine $(8.6 \mathrm{~mL}, 0.1 \mathrm{~mol}), n$-butyllithium $(0.8 \mathrm{~mL}, 10 \mathrm{mmol})$ and dry solvent THF $(10.0 \mathrm{~mL})$ were added into the reaction tube. The mixture was stirred at $-40^{\circ} \mathrm{C}$ for 3 hours. After the reaction solution returned to room temperature, anhydrous $\mathrm{CuCl}(0.9$ $\mathrm{mg}, 10 \mathrm{mmol}$ ) was added. The mixture was rapidly stirred for 3 hours, and oxygen was introduced at the same time. As the temperature elevated from $20^{\circ} \mathrm{C}$ to $36^{\circ} \mathrm{C}$, the color was changed from yellow to dark green. The reaction was stopped after 2 hours, and the solvent was removed under reduced pressure. Then, the reaction mixture was purified by column chromatography on silica gel and eluted with ethyl acetate/hexane $(1 / 20 \sim 1 / 2)$ to give the product 6 in $20 \%$ yield (344.0 mg, colorless crystal).

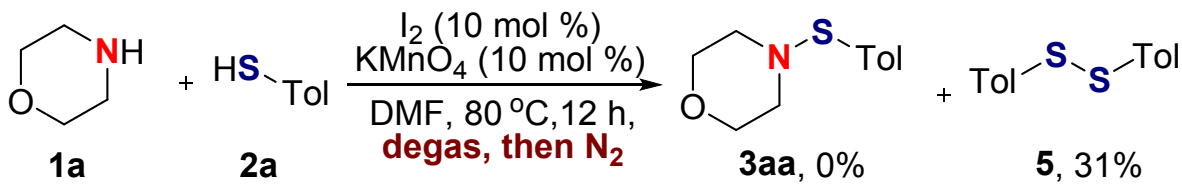

$\mathrm{I}_{2}(12.7 \mathrm{mg}, 0.05 \mathrm{mmol}), \mathrm{KMnO}_{4}(7.9 \mathrm{mg}, 0.05 \mathrm{mmol})$, morpholine 1a $(40.0 \mu \mathrm{L}$, $0.5 \mathrm{mmol})$, 4-methylbenzenethiol $2 \mathrm{a}(62.0 \mathrm{mg}, 0.5 \mathrm{mmol})$ and DMF (2.0 $\mathrm{mL})$ were added into the reaction tube. The mixture was degassed and then protected with a nitrogen balloon, which stirred at $80{ }^{\circ} \mathrm{C}$ for 12 hours. After cooling to room temperature, the reaction was quenched by $10 \mathrm{~mL}$ of $\mathrm{NaCl}$ saturated solution, The aqueous phase extracted with ethyl acetate $(3 \times 20 \mathrm{~mL})$ and the combined organic phases dried with $\mathrm{Na}_{2} \mathrm{SO}_{4}$. The solvent was removed under reduced pressure. Then the reaction mixture was purified by flash column chromatography on silica gel and eluted with ethyl acetate/hexane (1/200) to give the compound 5 (19.2 $\mathrm{mg}, 31 \%$ yield). Sulfenamide 3aa was not detected in this transformation.

The results suggested that oxygen is a key oxidant for the formation of the sulfenamide and the disulfide could also be generation in the absence of oxygen. 
(6)

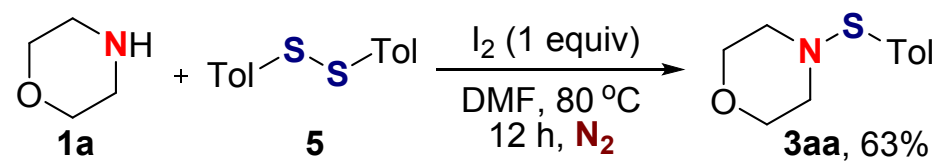

Under nitrogen atmosphere, $\mathrm{I}_{2}(127.0 \mathrm{mg}, 0.5 \mathrm{mmol})$, morpholine $1 \mathbf{a}(40.0 \mu \mathrm{L}, 0.5$ mmol), disulfide $5(61.5 \mathrm{mg}, 0.25 \mathrm{mmol})$ and DMF $(2.0 \mathrm{~mL})$ were added into the reaction tube. The mixture was stirred at $80{ }^{\circ} \mathrm{C}$ for 12 hours. After cooling to room temperature, the reaction was quenched by $10 \mathrm{~mL}$ of $\mathrm{NaCl}$ saturated solution, The aqueous phase extracted with ethyl acetate $(3 \times 20 \mathrm{~mL})$ and the combined organic phases dried with $\mathrm{Na}_{2} \mathrm{SO}_{4}$. The solvent was removed under reduced pressure. Then the reaction mixture was purified by flash column chromatography on silica gel and eluted with ethyl acetate/hexane $\left(1 / 200 \sim 1 / 50,3 \sim 5\right.$ drops of $\mathrm{Et}_{3} \mathrm{~N}$ in $200 \mathrm{~mL}$ of eluent) to give the desired product 3aa (65.6 $\mathrm{mg}, 63 \%$ yield).

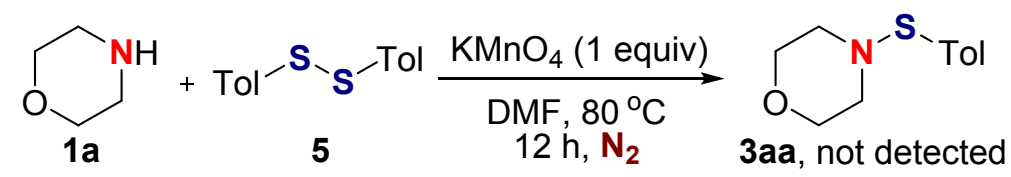

Under nitrogen atmosphere, $\mathrm{KMnO}_{4}(79.0 \mathrm{mg}, 0.5 \mathrm{mmol})$, morpholine $1 \mathrm{a}$ (40.0 $\mu \mathrm{L}, 0.5 \mathrm{mmol})$, disulfide $5(61.5 \mathrm{mg}, 0.25 \mathrm{mmol})$ and DMF (2.0 mL) were added into the reaction tube. The mixture was stirred at $80{ }^{\circ} \mathrm{C}$ for 12 hours. However, after cooling to room temperature, the product 3aa could not be detected by TLC.

(8)

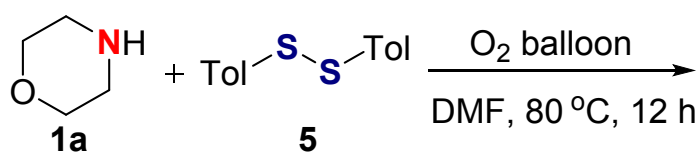<smiles>[AlH2]SN1CCOCC1</smiles>

3aa, not detected

Morpholine 1a $(40.0 \mu \mathrm{L}, 0.5 \mathrm{mmol})$, disulfide $5(61.5 \mathrm{mg}, 0.25 \mathrm{mmol})$ and DMF $(2.0 \mathrm{~mL})$ were added into the reaction tube under air. The mixture was stirred at $80{ }^{\circ} \mathrm{C}$ for 12 hours with an oxygen balloon. However, after cooling to room temperature, the product 3aa could not be detected by TLC.<smiles>C1COCCN1</smiles>

$1 \mathbf{a}$

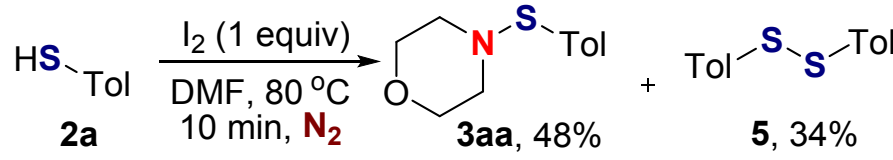
$5,34 \%$

Under nitrogen atmosphere, $\mathrm{I}_{2}(127.0 \mathrm{mg}, 0.5 \mathrm{mmol})$, morpholine $1 \mathbf{a}(40.0 \mu \mathrm{L}, 0.5$ mmol), 4-methylbenzenethiol 2a $(62.0 \mathrm{mg}, 0.5 \mathrm{mmol})$ and DMF $(2.0 \mathrm{~mL})$ were added 
into the reaction tube. The mixture was stirred at $80{ }^{\circ} \mathrm{C}$ for 12 hours. After cooling to room temperature, the reaction was quenched by $10 \mathrm{~mL}$ of $\mathrm{NaCl}$ saturated solution, The aqueous phase extracted with ethyl acetate $(3 \times 20 \mathrm{~mL})$ and the combined organic phases dried with $\mathrm{Na}_{2} \mathrm{SO}_{4}$. The solvent was removed under reduced pressure. Then the reaction mixture was purified by flash column chromatography on silica gel and eluted with ethyl acetate/hexane $\left(1 / 200 \sim 1 / 50,3 \sim 5\right.$ drops of $\mathrm{Et}_{3} \mathrm{~N}$ in $200 \mathrm{~mL}$ of eluent) to give the desired product 3aa (49.7 mg, 48\% yield) and disulfide 5 (20.9 mg, 34\% yield).

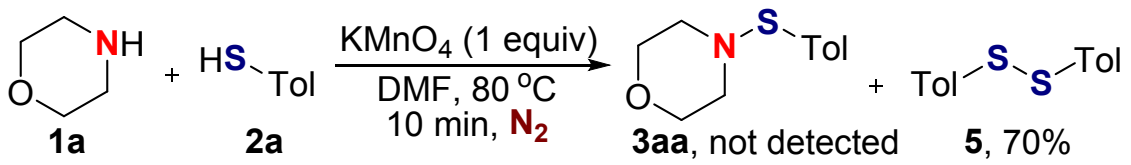

Under nitrogen atmosphere, $\mathrm{KMnO}_{4}(79.0 \mathrm{mg}, 0.5 \mathrm{mmol})$, morpholine $\mathbf{1 a}$ (40.0 $\mu \mathrm{L}, 0.5 \mathrm{mmol})$, 4-methylbenzenethiol 2a $(62.0 \mathrm{mg}, 0.5 \mathrm{mmol})$ and DMF (2.0 mL) were added into the reaction tube. The mixture was stirred at $80{ }^{\circ} \mathrm{C}$ for 12 hours. After cooling to room temperature, the product 3aa could not be detected by TLC. The reaction was quenched by $10 \mathrm{~mL}$ of $\mathrm{NaCl}$ saturated solution. The aqueous phase extracted with ethyl acetate $(3 \times 20 \mathrm{~mL})$ and the combined organic phases dried with $\mathrm{Na}_{2} \mathrm{SO}_{4}$. The solvent was removed under reduced pressure. Then the reaction mixture was purified by flash column chromatography on silica gel and eluted with ethyl acetate/hexane (1/200) to give the disulfide 5 (43.0 $\mathrm{mg}, 70 \%$ yield).

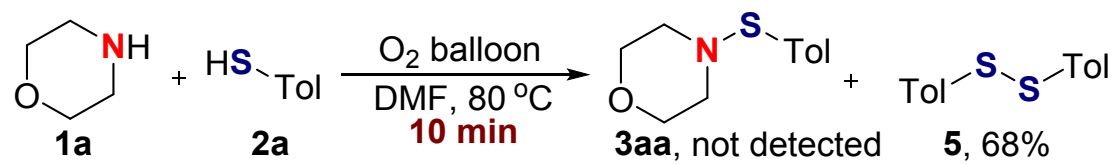

Morpholine 1a $(40.0 \mu \mathrm{L}, 0.5 \mathrm{mmol})$, 4-methylbenzenethiol 2a (62.0 mg, 0.5 mmol) and DMF (2.0 mL) were added into the reaction tube under air. The mixture was stirred at $80{ }^{\circ} \mathrm{C}$ for ten minutes with an oxygen balloon. After cooling to room temperature, the product 3aa could not be detected by TLC. The reaction was quenched by $10 \mathrm{~mL}$ of $\mathrm{NaCl}$ saturated solution. The aqueous phase extracted with ethyl acetate $(3 \times 20 \mathrm{~mL})$ and the combined organic phases dried with $\mathrm{Na}_{2} \mathrm{SO}_{4}$. The solvent was removed under reduced pressure. Then the reaction mixture was purified 
by flash column chromatography on silica gel and eluted with ethyl acetate/hexane (1/200) to give the disulfide 5 (41.9 $\mathrm{mg}, 68 \%$ yield).

The results of schemes (6)-(11) showed that the sulfenamide only could be formation in the presence of equivalent amount of iodine, thus the generation of sulfenamide is in the catalytic cycle of iodine rather than that of manganese.

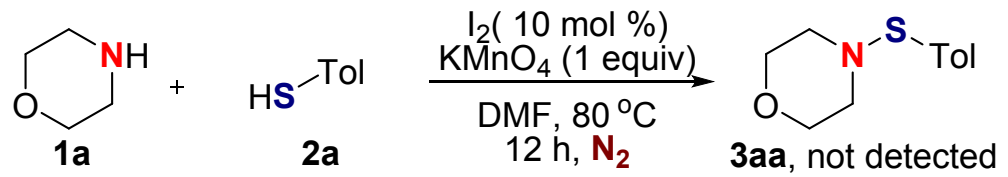

Under nitrogen atmosphere, $\mathrm{I}_{2}(12.7 \mathrm{mg}, 0.05 \mathrm{mmol}), \mathrm{KMnO}_{4}(79.0 \mathrm{mg}, 0.5$ mmol), morpholine 1a $(40.0 \mu \mathrm{L}, 0.5 \mathrm{mmol})$, 4-methylbenzenethiol $2 \mathrm{a}$ (62.0 $\mathrm{mg}, 0.5$ mmol) and DMF (2.0 mL) were added into the reaction tube. The mixture was stirred at $80{ }^{\circ} \mathrm{C}$ for 12 hours. After cooling to room temperature, the product 3aa could not be detected by TLC.

The results suggested that oxygen is a terminal oxidant for the formation of the sulfenamide.

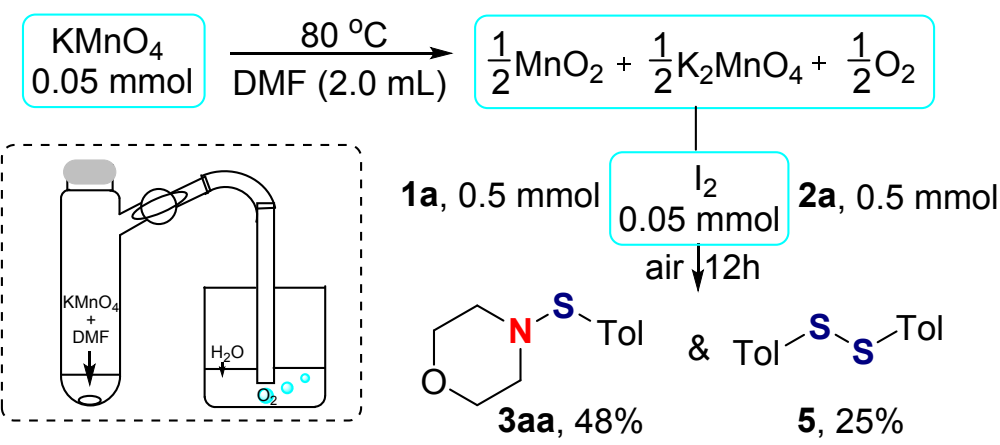

In the air, $\mathrm{KMnO}_{4}(7.9 \mathrm{mg}, 0.05 \mathrm{mmol})$ and $\mathrm{DMF}(2.0 \mathrm{~mL})$ were heated at $80{ }^{\circ} \mathrm{C}$, and the reaction is passed into a beaker containing water. Oxygen bubbles could be observed in the water, implying that activated $\mathrm{MnO}_{2}$ might be produced. After oxygen bubbles stopped releasing, $\mathrm{I}_{2}(12.7 \mathrm{mg}, 0.05 \mathrm{mmol})$, morpholine 1a $(40.0 \mu \mathrm{L}, 0.5$ mmol), 4-methylbenzenethiol $2 \mathrm{a}(62.0 \mathrm{mg}, 0.5 \mathrm{mmol})$ were rapidly added into the reaction tube under air. The mixture was stirred at $80{ }^{\circ} \mathrm{C}$ for 12 hours. After cooling to room temperature, the reaction was quenched by $10 \mathrm{~mL}$ of $\mathrm{NaCl}$ saturated solution, The aqueous phase extracted with ethyl acetate $(3 \times 20 \mathrm{~mL})$ and the combined organic phases dried with $\mathrm{Na}_{2} \mathrm{SO}_{4}$. The solvent was removed under reduced pressure. Then the 
reaction mixture was purified by flash column chromatography on silica gel and eluted with ethyl acetate/hexane (1/200 1/50, 3 5 drops of $\mathrm{Et}_{3} \mathrm{~N}$ in $200 \mathrm{~mL}$ of eluent) to give the desired product 3aa (50.2 mg, 48\% yield) and disulfide 5 (15.2 mg, 25\% yield).

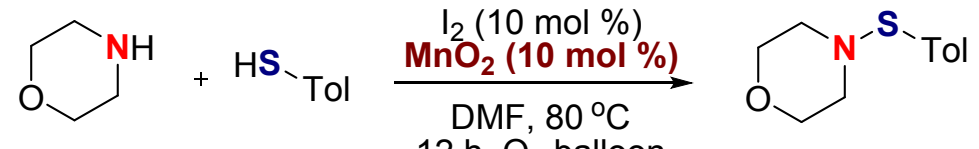

$1 \mathrm{a}$

2a

$12 \mathrm{~h}, \mathrm{O}_{2}$ balloon

3aa

a. Freshly prepared $\mathrm{MnO}_{2}$ from $\mathrm{KMnO}_{4}$ under acidic conditions: $3 \mathrm{aa}, 70 \%$;

b. Freshly prepared $\mathrm{MnO}_{2}$ from $\mathrm{KMnO}_{4}$ under basic conditions: $3 \mathrm{aa}, 28 \%$;

c. Freshly prepared $\mathrm{MnO}_{2}$ from $\mathrm{KMnO}_{4}$ under neutral conditions: $3 \mathbf{a a}, 7 \%$;

d. Commercially available $\mathrm{MnO}_{2}$ was calcined at $250^{\circ} \mathrm{C}$ for $3 \mathrm{~h}: 3 \mathrm{aa}, 36 \%$.

$\mathrm{I}_{2}(12.7 \mathrm{mg}, 0.05 \mathrm{mmol}), \mathrm{MnO}_{2}(4.3 \mathrm{mg}, 0.05 \mathrm{mmol})$, morpholine $1 \mathrm{a}(40.0 \mu \mathrm{L}, 0.5$ mmol), 4-methylbenzenethiol 2a (62.0 mg, $0.5 \mathrm{mmol})$, and DMF (2.0 mL) were added into the reaction tube under air. The mixture was stirred at $80{ }^{\circ} \mathrm{C}$ for 12 hours with an oxygen balloon. After cooling to room temperature, the reaction was quenched by 10 $\mathrm{mL}$ of $\mathrm{NaCl}$ saturated solution, The aqueous phase extracted with ethyl acetate $(3 \times 20$ $\mathrm{mL}$ ) and the combined organic phases dried with $\mathrm{Na}_{2} \mathrm{SO}_{4}$. The solvent was removed under reduced pressure. Then the reaction mixture was purified by flash column chromatography on silica gel and eluted with ethyl acetate/hexane $(1 / 200 \sim 1 / 50,3 \sim 5$ drops of $\mathrm{Et}_{3} \mathrm{~N}$ in $200 \mathrm{~mL}$ of eluent) to give the desired product 3aa.

This results of scheme (13) and (14) demonstrated that $\mathrm{MnO}_{2}$ is an active species in the catalytic cycle.

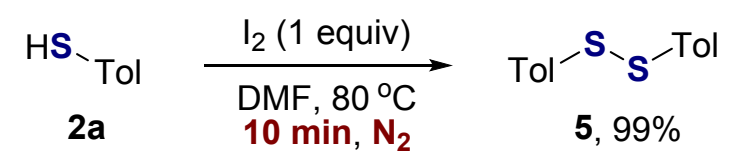

Under nitrogen atmosphere, $\mathrm{I}_{2}(127.0 \mathrm{mg}, 0.5 \mathrm{mmol})$, 4-methylbenzenethiol 2a (62.0 $\mathrm{mg}, 0.5 \mathrm{mmol})$ and DMF $(2.0 \mathrm{~mL})$ were added into the reaction tube. The mixture was stirred at $80{ }^{\circ} \mathrm{C}$ for ten minutes. After cooling to room temperature, the reaction was quenched by $10 \mathrm{~mL}$ of $\mathrm{NaCl}$ saturated solution, The aqueous phase extracted with ethyl acetate $(3 \times 20 \mathrm{~mL})$ and the combined organic phases dried with $\mathrm{Na}_{2} \mathrm{SO}_{4}$. The solvent was removed under reduced pressure. Then the reaction mixture 
was purified by flash column chromatography on silica gel and eluted with ethyl acetate/hexane (1/200) to give the disulfide 5 (61.1 mg, 99\% yield).

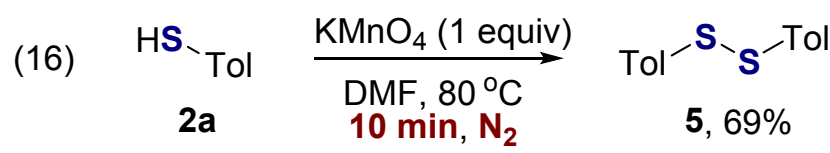

Under nitrogen atmosphere, $\mathrm{KMnO}_{4}(79.0 \mathrm{mg}, 0.5 \mathrm{mmol})$, 4-methylbenzenethiol 2a $(62.0 \mathrm{mg}, 0.5 \mathrm{mmol})$ and $\mathrm{DMF}(2.0 \mathrm{~mL})$ were added into the reaction tube. The mixture was stirred at $80{ }^{\circ} \mathrm{C}$ for ten minutes. After cooling to room temperature, the reaction was quenched by $10 \mathrm{~mL}$ of $\mathrm{NaCl}$ saturated solution, The aqueous phase extracted with ethyl acetate $(3 \times 20 \mathrm{~mL})$ and the combined organic phases dried with $\mathrm{Na}_{2} \mathrm{SO}_{4}$. The solvent was removed under reduced pressure. Then the reaction mixture was purified by flash column chromatography on silica gel and eluted with ethyl acetate/hexane (1/200) to give the disulfide 5 (42.4 mg, 69\% yield).

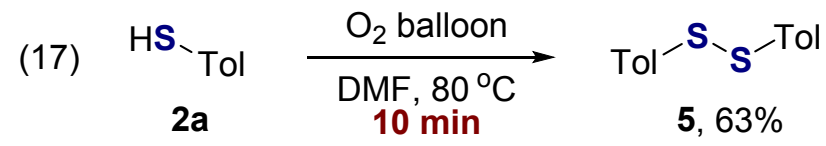

4-Methylbenzenethiol 2a (62.0 mg, $0.5 \mathrm{mmol})$ and DMF $(2.0 \mathrm{~mL})$ were added into the reaction tube under air. The mixture was stirred at $80{ }^{\circ} \mathrm{C}$ for ten minutes with an oxygen balloon. After cooling to room temperature, the reaction was quenched by $10 \mathrm{~mL}$ of $\mathrm{NaCl}$ saturated solution, The aqueous phase extracted with ethyl acetate $(3 \times 20 \mathrm{~mL})$ and the combined organic phases dried with $\mathrm{Na}_{2} \mathrm{SO}_{4}$. The solvent was removed under reduced pressure. Then the reaction mixture was purified by flash column chromatography on silica gel and eluted with ethyl acetate/hexane (1/200) to give the give the disulfide 5 (38.6 mg, 63\% yield).

The resluts of scheme (14)-(16) further proved that thiols could be oxidized by oxygen, the stoichiometric amount of iodine or potassium permanganate.

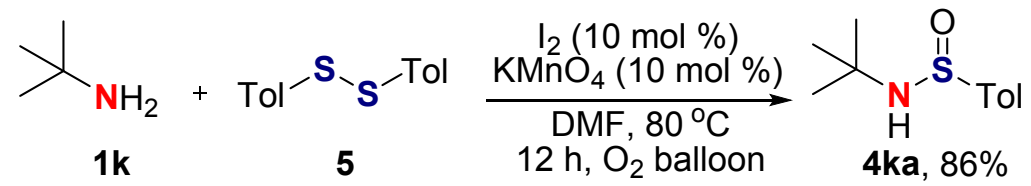

$\mathrm{I}_{2}(12.7 \mathrm{mg}, 0.05 \mathrm{mmol}), \mathrm{KMnO}_{4}(7.9 \mathrm{mg}, 0.05 \mathrm{mmol})$, amine $1 \mathbf{k}(108.0 \mu \mathrm{L}, 1$ mmol), disulfide $5(61.5 \mathrm{mg}, 0.25 \mathrm{mmol})$ and DMF $(2.0 \mathrm{~mL})$ were added into the reaction tube under air. The mixture was stirred at $80{ }^{\circ} \mathrm{C}$ for 12 hours with an oxygen 
balloon. After cooling to room temperature, the reaction was quenched by $10 \mathrm{~mL}$ of $\mathrm{NaCl}$ saturated solution, The aqueous phase extracted with ethyl acetate $(3 \times 20 \mathrm{~mL})$ and the combined organic phases dried with $\mathrm{Na}_{2} \mathrm{SO}_{4}$. The solvent was removed under reduced pressure. Then the reaction mixture was purified by column chromatography on silica gel and eluted with ethyl acetate/hexane $(1 / 20 \sim 1 / 2)$ to give the desired product $4 \mathbf{k a}$ (45.6 $\mathrm{mg}, 86 \%$ yield).

This results demonstrated that the mechanism of primary amines is similar to that of secondary amines in the transformation. 


\section{Synthetic application}

(1) Synthesis of antihypertensive activity derivative IV<smiles>Clc1ccc(N2CCNCC2)cc1</smiles>

$1 f$<smiles>Sc1ccccc1</smiles>

3u

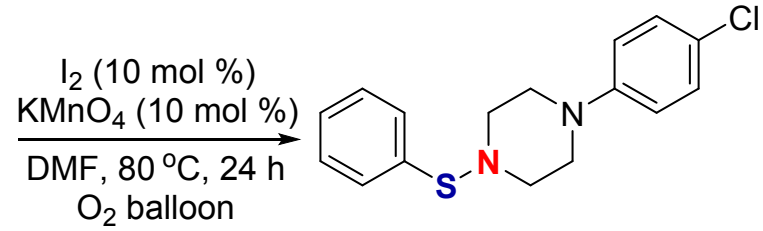

IV, $64 \%$

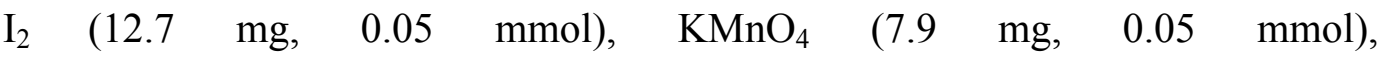
1-(4-chlorophenyl)piperazine $\mathbf{1 f}(196.0 \mathrm{mg}, 1 \mathrm{mmol})$, thiophenol $\mathbf{3 u}(51.0 \mu \mathrm{L}, 0.5$ mmol) and DMF $(2.0 \mathrm{~mL})$ were added into the reaction tube under air. The mixture was stirred at $80{ }^{\circ} \mathrm{C}$ for 24 hours with an oxygen balloon. After cooling to room temperature, the reaction was quenched by $10 \mathrm{~mL}$ of $\mathrm{NaCl}$ saturated solution, The aqueous phase extracted with ethyl acetate $(3 \times 20 \mathrm{~mL})$ and the combined organic phases dried with $\mathrm{Na}_{2} \mathrm{SO}_{4}$. The solvent was removed under reduced pressure. Then the reaction mixture was purified by flash column chromatography on silica gel and eluted with ethyl acetate/hexane $\left(1 / 200 \sim 1 / 100,3 \sim 5\right.$ drops of $\mathrm{Et}_{3} \mathrm{~N}$ in $200 \mathrm{~mL}$ of eluent) to give the desired product IV (97.3 mg, 64\% yield, white solid).

\section{(2) 1 mmol scale experiment}

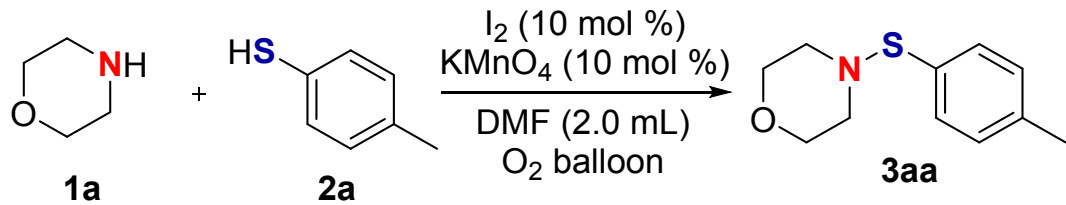

$\mathrm{I}_{2}(25.4 \mathrm{mg}, 0.05 \mathrm{mmol}), \mathrm{KMnO}_{4}(15.8 \mathrm{mg}, 0.05 \mathrm{mmol})$, morpholine $1 \mathrm{a}(80.0 \mu \mathrm{L}$, $1 \mathrm{mmol})$, 4-methylbenzenethiol 2a (124.0 mg, $1 \mathrm{mmol})$ and DMF (2.0 mL) were added into the reaction tube under air. The mixture was stirred at $80^{\circ} \mathrm{C}$ for 12 hours with an oxygen balloon. After cooling to room temperature, the reaction was quenched by 10 $\mathrm{mL}$ of $\mathrm{NaCl}$ saturated solution, The aqueous phase extracted with ethyl acetate $(3 \times 20$ $\mathrm{mL}$ ) and the combined organic phases dried with $\mathrm{Na}_{2} \mathrm{SO}_{4}$. The solvent was removed under reduced pressure. Then the reaction mixture was purified by flash column chromatography on silica gel and eluted with ethyl acetate/hexane (1/200 1/50, 3 5 
drops of $\mathrm{Et}_{3} \mathrm{~N}$ in $200 \mathrm{~mL}$ of eluent) to give the desired product 3aa $(153.1 \mathrm{mg}, 73 \%$ yield). 


\section{Experimental characterization data for product}

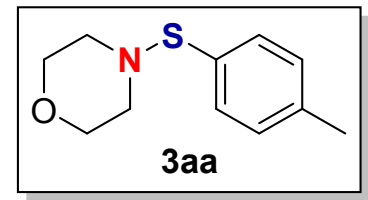

4-(p-Tolylthio)morpholine (3aa) ${ }^{\mathbf{1}, 2}$ : The title compound was prepared according to the general procedure and purified by flash column chromatography on silica gel to give the light yellow oil, $84.0 \mathrm{mg}, 80 \%$ yield. ${ }^{1} \mathrm{H}$ NMR $\left(400 \mathrm{MHz}, \mathrm{CDCl}_{3}\right) \delta 7.31$ (d, $J$ $=8.0 \mathrm{~Hz}, 2 \mathrm{H}), 7.10(\mathrm{~d}, J=8.0 \mathrm{~Hz}, 2 \mathrm{H}), 3.60(\mathrm{t}, J=4.8 \mathrm{~Hz}, 4 \mathrm{H}), 2.80(\mathrm{t}, J=4.8 \mathrm{~Hz}$, 4H), $2.28(\mathrm{~s}, 3 \mathrm{H}) .{ }^{13} \mathrm{C} \mathrm{NMR}\left(100 \mathrm{MHz}, \mathrm{CDCl}_{3}\right) \delta 139.0,133.2,129.5,129.0,67.6$, 55.9, 21.3. HRMS (ESI) calcd. for $\mathrm{C}_{11} \mathrm{H}_{16} \mathrm{NOS}[\mathrm{M}+\mathrm{H}]: 210.0947$, found: 210.0953 .

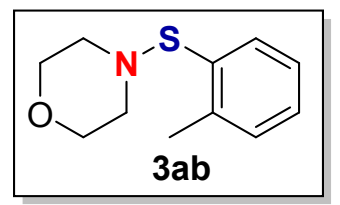

4-(o-Tolylthio)morpholine (3ab): The title compound was prepared according to the general procedure and purified by flash column chromatography on silica gel to give the light yellow oil, $69.0 \mathrm{mg}, 66 \%$ yield. ${ }^{1} \mathrm{H}$ NMR (400 MHz, $\left.\mathrm{CDCl}_{3}\right) \delta 7.58(\mathrm{~d}, J=7.6$ $\mathrm{Hz}, 1 \mathrm{H}), 7.23-7.18(\mathrm{~m}, 1 \mathrm{H}), 7.16-7.09(\mathrm{~m}, 2 \mathrm{H}), 3.74$ (t, $J=4.8 \mathrm{~Hz}, 4 \mathrm{H}), 3.00$ (t, $J=4.8$ $\mathrm{Hz}, 4 \mathrm{H}), 2.29$ (s, 3H). ${ }^{13} \mathrm{C} \mathrm{NMR}\left(100 \mathrm{MHz}, \mathrm{CDCl}_{3}\right) \delta 136.2,135.3,130.4,127.2,126.5$, 126.1, 67.9, 56.2, 19.5. HRMS (ESI) calcd. for $\mathrm{C}_{11} \mathrm{H}_{16} \mathrm{NOS}[\mathrm{M}+\mathrm{H}]: 210.0947$, found: 210.0949 .

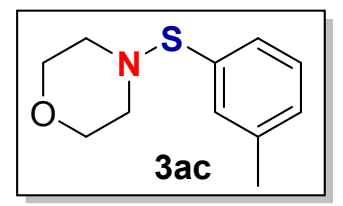

4-(m-Tolylthio)morpholine (3ac): The title compound was prepared according to the general procedure and purified by flash column chromatography on silica gel to give the light yellow oil, $73.2 \mathrm{mg}, 70 \%$ yield. ${ }^{1} \mathrm{H}$ NMR (400 MHz, $\left.\mathrm{CDCl}_{3}\right) \delta 7.30-7.24$ (m, $3 \mathrm{H}), 7.10(\mathrm{~d}, J=6.8 \mathrm{~Hz}, 1 \mathrm{H}), 3.70(\mathrm{t}, J=4.8 \mathrm{~Hz}, 4 \mathrm{H}), 2.94(\mathrm{t}, J=4.8 \mathrm{~Hz}, 4 \mathrm{H}), 2.36$ (s, $3 \mathrm{H}) .{ }^{13} \mathrm{C} \mathrm{NMR}\left(100 \mathrm{MHz}, \mathrm{CDCl}_{3}\right) \delta 138.5,134.0,131.4,128.9,128.6,128.0,67.7$, 56.1, 21.5. HRMS (ESI) calcd. for $\mathrm{C}_{11} \mathrm{H}_{16} \mathrm{NOS}[\mathrm{M}+\mathrm{H}]: 210.0947$, found: 210.0952 . 


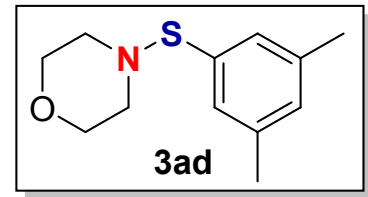

4-((3,5-Dimethylphenyl)thio)morpholine (3ad): The title compound was prepared according to the general procedure and purified by flash column chromatography on silica gel to give the light yellow oil, $73.0 \mathrm{mg}, 65 \%$ yield. ${ }^{1} \mathrm{H}$ NMR (400 $\mathrm{MHz}, \mathrm{CDCl}_{3}$ ) $\delta 7.08(\mathrm{~s}, 2 \mathrm{H}), 6.93(\mathrm{~s}, 1 \mathrm{H}), 3.70(\mathrm{t}, J=4.8 \mathrm{~Hz}, 4 \mathrm{H}), 2.94(\mathrm{t}, J=4.8 \mathrm{~Hz}, 4 \mathrm{H}), 2.32(\mathrm{~s}$, $6 \mathrm{H}) .{ }^{13} \mathrm{C} \mathrm{NMR}\left(100 \mathrm{MHz}, \mathrm{CDCl}_{3}\right) \delta 138.3,133.7,129.9,128.7,67.7,56.1,21.3$. HRMS (ESI) calcd. for $\mathrm{C}_{12} \mathrm{H}_{18} \mathrm{NOS}$ [M+H]: 224.1104, found: 224.1106 .

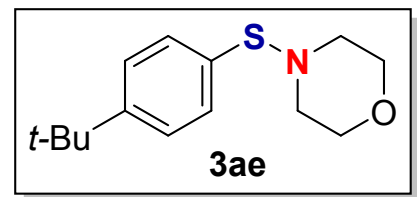

4-((4-(tert-Butyl)phenyl)thio)morpholine (3ae): The title compound was prepared according to the general procedure and purified by flash column chromatography on silica gel to give a light yellow solid, $93.0 \mathrm{mg}, 74 \%$ yield. ${ }^{1} \mathrm{H}$ NMR (400 $\left.\mathrm{MHz}, \mathrm{CDCl}_{3}\right)$ $\delta 7.43(\mathrm{~d}, J=4.4 \mathrm{~Hz}, 2 \mathrm{H}), 7.38(\mathrm{~d}, J=4.4 \mathrm{~Hz}, 2 \mathrm{H}), 3.69(\mathrm{t}, J=4.8 \mathrm{~Hz}, 4 \mathrm{H}), 2.91$ (t, $J$ $=4.8 \mathrm{~Hz}, 4 \mathrm{H}), 1.33(\mathrm{~s}, 9 \mathrm{H}) .{ }^{13} \mathrm{C} \mathrm{NMR}\left(100 \mathrm{MHz}, \mathrm{CDCl}_{3}\right) \delta 151.9,132.5,129.5,125.7$, 67.7, 55.9, 34.7, 31.3. HRMS (ESI) calcd. for $\mathrm{C}_{14} \mathrm{H}_{22} \mathrm{NOS}[\mathrm{M}+\mathrm{H}]$ : 252.1417, found: 252.1415 .

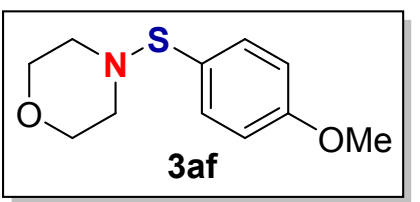

4-((4-Methoxyphenyl)thio)morpholine (3af) ${ }^{2}$ : The title compound was prepared according to the general procedure and purified by flash column chromatography on silica gel to give the light yellow oil, $75.0 \mathrm{mg}, 67 \%$ yield. ${ }^{1} \mathrm{H}$ NMR (400 $\mathrm{MHz}, \mathrm{CDCl}_{3}$ ) $\delta 7.48(\mathrm{~d}, J=8.4 \mathrm{~Hz}, 2 \mathrm{H}), 6.91(\mathrm{~d}, J=8.8 \mathrm{~Hz}, 2 \mathrm{H}), 3.83(\mathrm{~s}, 3 \mathrm{H}), 3.60$ (t, $J=4.8 \mathrm{~Hz}$, 4H), 2.82 (t, $J=4.8 \mathrm{~Hz}, 4 \mathrm{H}) .{ }^{13} \mathrm{C} \mathrm{NMR}\left(100 \mathrm{MHz}, \mathrm{CDCl}_{3}\right) \delta 160.9,137.2,121.8$, 114.1, 67.6, 55.6, 55.4. HRMS (ESI) calcd. for $\mathrm{C}_{11} \mathrm{H}_{16} \mathrm{NO}_{2} \mathrm{~S}[\mathrm{M}+\mathrm{H}]$ : 226.0896, found: 226.0890 . 


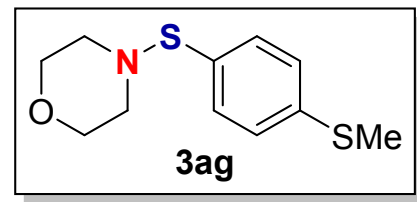

4-((4-(Methylthio)phenyl)thio)morpholine (3ag): The title compound was prepared according to the general procedure and purified by flash column chromatography on silica gel to give the yellow oil, $83.0 \mathrm{mg}, 69 \%$ yield. ${ }^{1} \mathrm{H}$ NMR (400 $\left.\mathrm{MHz}, \mathrm{CDCl}_{3}\right) \delta$ $7.41(\mathrm{~d}, J=8.4 \mathrm{~Hz}, 2 \mathrm{H}), 7.24(\mathrm{~d}, J=8.4 \mathrm{~Hz}, 2 \mathrm{H}), 3.69$ (t, $J=4.8 \mathrm{~Hz}, 4 \mathrm{H}), 2.88(\mathrm{t}, J=$ $4.8 \mathrm{~Hz}, 4 \mathrm{H}), 2.49$ (s, 3H). ${ }^{13} \mathrm{C} \mathrm{NMR}\left(100 \mathrm{MHz}, \mathrm{CDCl}_{3}\right) \delta 139.9,133.1,129.0,126.3$, 67.6, 55.9, 15.6.; HRMS (ESI) calcd. for $\mathrm{C}_{11} \mathrm{H}_{16} \mathrm{NOS}_{2}[\mathrm{M}+\mathrm{H}]$ : 242.0668, found: 242.0669 .

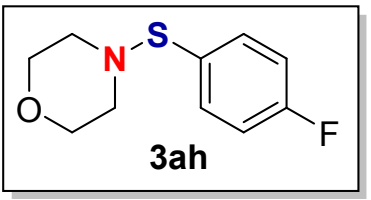

4-((4-Fluorophenyl)thio)morpholine (3ah) ${ }^{2}$ : The title compound was prepared according to the general procedure and purified by flash column chromatography on silica gel to give the light yellow oil, $70.0 \mathrm{mg}, 66 \%$ yield. ${ }^{1} \mathrm{H}$ NMR $\left(400 \mathrm{MHz}, \mathrm{CDCl}_{3}\right.$ ) $\delta 7.49(\mathrm{dd}, J=8.8 \mathrm{~Hz}, 5.6 \mathrm{~Hz}, 2 \mathrm{H}), 7.08(\mathrm{t}, J=8.8 \mathrm{~Hz}, 2 \mathrm{H}), 3.69$ (t, $J=4.8 \mathrm{~Hz}, 4 \mathrm{H})$, $2.88(\mathrm{t}, J=4.8 \mathrm{~Hz}, 4 \mathrm{H}) .{ }^{13} \mathrm{C} \mathrm{NMR}\left(100 \mathrm{MHz}, \mathrm{CDCl}_{3}\right) \delta 163.3(\mathrm{~d}, J=250 \mathrm{~Hz}), 135.1(\mathrm{~d}$, $J=10 \mathrm{~Hz}), 127.9,115.9(\mathrm{~d}, J=20 \mathrm{~Hz}), 67.6,55.8 .{ }^{19} \mathrm{~F} \mathrm{NMR}\left(376 \mathrm{MHz}, \mathrm{CDCl}_{3}\right) \delta$ $-112.2$.

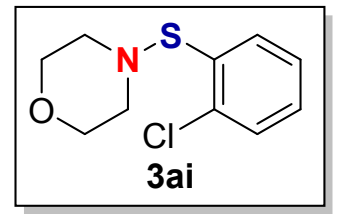

4-((2-Chlorophenyl)thio)morpholine (3ai): The title compound was prepared according to the general procedure and purified by flash column chromatography on silica gel to give the yellow oil, $87.3 \mathrm{mg}, 76 \%$ yield. ${ }^{1} \mathrm{H}$ NMR $\left(400 \mathrm{MHz}, \mathrm{CDCl}_{3}\right) \delta$ $7.52(\mathrm{dd}, J=8.0 \mathrm{~Hz}, 1.6 \mathrm{~Hz}, 1 \mathrm{H}), 7.25-7.17(\mathrm{~m}, 2 \mathrm{H}), 7.05-6.98(\mathrm{~m}, 1 \mathrm{H}), 3.68(\mathrm{t}, J=$ $4.8 \mathrm{~Hz}, 4 \mathrm{H}), 2.98(\mathrm{t}, J=4.8 \mathrm{~Hz}, 4 \mathrm{H}) .{ }^{13} \mathrm{C} \mathrm{NMR}\left(100 \mathrm{MHz}, \mathrm{CDCl}_{3}\right) \delta 137.8,129.6$, 129.2, 127.0, 126.6, 126.1, 67.8, 56.1. HRMS (ESI) calcd. for $\mathrm{C}_{10} \mathrm{H}_{13} \mathrm{CINOS}[\mathrm{M}+\mathrm{H}]$ : 230.0401, found: 230.0403 . 


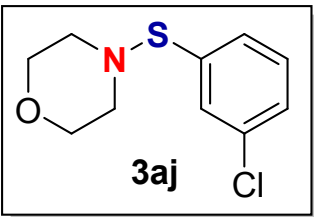

4-((3-Chlorophenyl)thio)morpholine (3aj): The title compound was prepared according to the general procedure and purified by flash column chromatography on silica gel to give the yellow oil, $97.6 \mathrm{mg}, 85 \%$ yield. ${ }^{1} \mathrm{H}$ NMR $\left(400 \mathrm{MHz}, \mathrm{CDCl}_{3}\right) \delta$ 7.42-7.41 (m, 1H), 7.26-7.23 (m, 2H), 7.22-7.19 (m, 1H), $3.73(\mathrm{t}, J=4.8 \mathrm{~Hz}, 4 \mathrm{H}), 2.99$ $(\mathrm{t}, J=4.8 \mathrm{~Hz}, 4 \mathrm{H}) .{ }^{13} \mathrm{C} \mathrm{NMR}\left(100 \mathrm{MHz}, \mathrm{CDCl}_{3}\right) \delta 138.5,134.8,129.8,127.8,127.2$, 126.2, 67.7, 56.2. HRMS (ESI) calcd. for $\mathrm{C}_{10} \mathrm{H}_{13} \mathrm{CINOS}[\mathrm{M}+\mathrm{H}]: 230.0401$, found: 230.0403.

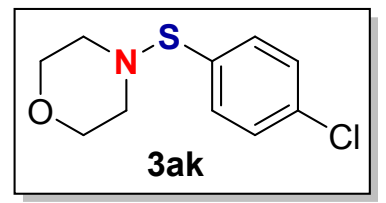

4-((4-Chlorophenyl)thio)morpholine (3ak) ${ }^{2}$ : The title compound was prepared according to the general procedure and purified by flash column chromatography on silica gel to give the yellow oil, $86.1 \mathrm{mg}, 75 \%$ yield. ${ }^{1} \mathrm{H}$ NMR $\left(400 \mathrm{MHz}, \mathrm{CDCl}_{3}\right) \delta$ 7.33-7.29 (m, 2H), 7.27-7.24 (m, 2H), $3.64(\mathrm{t}, J=4.8 \mathrm{~Hz}, 4 \mathrm{H}), 2.86(\mathrm{t}, J=4.8 \mathrm{~Hz}, 4 \mathrm{H})$. ${ }^{13} \mathrm{C}$ NMR $\left(100 \mathrm{MHz}, \mathrm{CDCl}_{3}\right) \delta 133.9,133.2,131.5,128.9,67.7,56.0$.<smiles>Brc1ccccc1SN1CCOCC1</smiles>

4-((2-Bromophenyl)thio)morpholine (3al): The title compound was prepared according to the general procedure and purified by flash column chromatography on silica gel to give the light yellow oil, $104 \mathrm{mg}, 76 \%$ yield. ${ }^{1} \mathrm{H}$ NMR (400 $\mathrm{MHz}, \mathrm{CDCl}_{3}$ ) $\delta 7.58(\mathrm{t}, J=1.6 \mathrm{~Hz}, 1 \mathrm{H}), 7.38-7.35(\mathrm{~m}, 1 \mathrm{H}), 7.32-7.29(\mathrm{~m}, 1 \mathrm{H}), 7.21(\mathrm{t}, J=8.0 \mathrm{~Hz}$, $1 \mathrm{H}), 3.73(\mathrm{t}, J=4.8 \mathrm{~Hz}, 4 \mathrm{H}), 2.99(\mathrm{t}, J=4.8 \mathrm{~Hz}, 4 \mathrm{H}) .{ }^{13} \mathrm{C} \mathrm{NMR}\left(100 \mathrm{MHz}, \mathrm{CDCl}_{3}\right) \delta$ 138.7, 130.7, 130.1(2C), 126.7, 122.9, 67.7, 56.2. HRMS (ESI) calcd. for $\mathrm{C}_{10} \mathrm{H}_{13} \operatorname{BrNOS}[\mathrm{M}+\mathrm{H}]:$ 273.9896, found: 273.9903. 


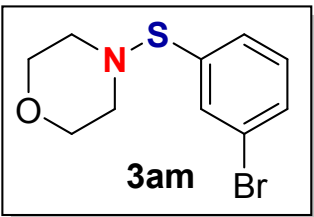

4-((3-Bromophenyl)thio)morpholine (3am): The title compound was prepared according to the general procedure and purified by flash column chromatography on silica gel to give the light yellow oil, $96.0 \mathrm{mg}, 70 \%$ yield. ${ }^{1} \mathrm{H}$ NMR (400 $\mathrm{MHz}, \mathrm{CDCl}_{3}$ ) $\delta 7.58(\mathrm{dd}, J=6.8 \mathrm{~Hz}, 1.6 \mathrm{~Hz}, 1 \mathrm{H}), 7.47(\mathrm{dd}, J=8.0 \mathrm{~Hz}, 1.2 \mathrm{~Hz}, 1 \mathrm{H}), 7.35-7.31$ (m, 1H), 7.04-6.99 (m, 1H), $3.78(\mathrm{t}, J=4.8 \mathrm{~Hz}, 4 \mathrm{H}), 3.09(\mathrm{t}, J=4.8 \mathrm{~Hz}, 4 \mathrm{H}) .{ }^{13} \mathrm{C} \mathrm{NMR}$ $\left(100 \mathrm{MHz}, \mathrm{CDCl}_{3}\right) \delta 140.1,132.8,127.6,126.6,125.3,117.6,67.9,56.1$. HRMS (ESI) calcd. for $\mathrm{C}_{10} \mathrm{H}_{13} \mathrm{BrNOS}[\mathrm{M}+\mathrm{H}]: 273.9896$, found: 273.9899 .<smiles>Brc1ccc(SN2CCOCC2)cc1</smiles>

4-((4-Bromophenyl)thio)morpholine (3an)²: The title compound was prepared according to the general procedure and purified by flash column chromatography on silica gel to give the yellow oil, $104 \mathrm{mg}, 76 \%$ yield. ${ }^{1} \mathrm{H}$ NMR $\left(400 \mathrm{MHz}, \mathrm{CDCl}_{3}\right) \delta$ $7.47(\mathrm{~d}, J=8.4 \mathrm{~Hz}, 2 \mathrm{H}), 7.30(\mathrm{~d}, J=8.4 \mathrm{~Hz}, 2 \mathrm{H}), 3.71(\mathrm{t}, J=4.8 \mathrm{~Hz}, 4 \mathrm{H}), 2.94(\mathrm{t}, J=$ $4.8 \mathrm{~Hz}, 4 \mathrm{H}) .{ }^{13} \mathrm{C} \mathrm{NMR}\left(100 \mathrm{MHz}, \mathrm{CDCl}_{3}\right) \delta 134.2,131.9,131.3,121.8,67.7,56.1$. HRMS (ESI) calcd. for $\mathrm{C}_{10} \mathrm{H}_{13} \mathrm{BrNOS}$ [M+H]: 273.9896, found: 273.9899 .<smiles>COc1ccccc1SN1CCOCC1</smiles>

Methyl 2-(morpholinothio)benzoate (3ao) ${ }^{3}$ : The title compound was prepared according to the general procedure and purified by flash column chromatography on silica gel to give a white solid, $78.0 \mathrm{mg}, 62 \%$ yield. ${ }^{1} \mathrm{H}$ NMR $\left(400 \mathrm{MHz}, \mathrm{CDCl}_{3}\right) \delta$ 7.96-7.92 (m, 2H), 7.49-7.44 (m, 1H), 7.10-7.05 (m, 1H), $3.82(\mathrm{~s}, 3 \mathrm{H}), 3.73(\mathrm{t}, J=4.8$ $\mathrm{Hz}, 4 \mathrm{H}), 2.99(\mathrm{t}, J=4.8 \mathrm{~Hz}, 4 \mathrm{H}) .{ }^{13} \mathrm{C} \mathrm{NMR}\left(100 \mathrm{MHz}, \mathrm{CDCl}_{3}\right) \delta 166.9,146.9,132.9$, 131.3, 123.8, 123.1, 122.6, 67.8, 55.5, 52.2. HRMS (ESI) calcd. for $\mathrm{C}_{12} \mathrm{H}_{15} \mathrm{NNaO}_{3} \mathrm{~S}$ [M+Na]: 276.0665, found: 276.0674 . 


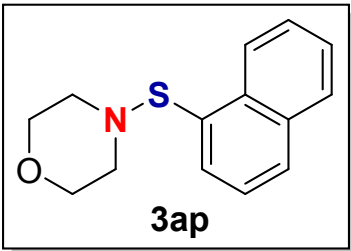

4-(Naphthalen-1-ylthio)morpholine (3ap): The title compound was prepared according to the general procedure and purified by flash column chromatography on silica gel to give the light yellow oil, $100.0 \mathrm{mg}, 82 \%$ yield. ${ }^{1} \mathrm{H}$ NMR (400 $\mathrm{MHz}, \mathrm{CDCl}_{3}$ ) $\delta 8.39(\mathrm{~d}, J=7.6 \mathrm{~Hz}, 1 \mathrm{H}), 7.86-7.80(\mathrm{~m}, 3 \mathrm{H}), 7.55-7.46(\mathrm{~m}, 3 \mathrm{H}), 3.70(\mathrm{t}, J=4.8 \mathrm{~Hz}$, 4H), $2.95(\mathrm{t}, J=4.8 \mathrm{~Hz}, 4 \mathrm{H}) .{ }^{13} \mathrm{C} \mathrm{NMR}\left(100 \mathrm{MHz}, \mathrm{CDCl}_{3}\right) \delta 134.0,133.1,131.3$, 130.1, 128.9, 128.4, 126.4, 126.2, 125.3, 125.0, 67.7, 56.2. HRMS (ESI) calcd. for $\mathrm{C}_{14} \mathrm{H}_{16} \mathrm{NOS}[\mathrm{M}+\mathrm{H}]: 246.0947$, found: 246.0944.

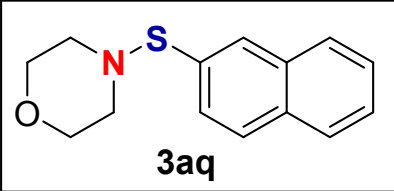

4-(Naphthalen-2-ylthio)morpholine (3aq): The title compound was prepared according to the general procedure and purified by flash column chromatography on silica gel to give the light yellow oil, $65.0 \mathrm{mg}, 53 \%$ yield. ${ }^{1} \mathrm{H} \mathrm{NMR}\left(400 \mathrm{MHz}, \mathrm{CDCl}_{3}\right.$ ) $\delta 7.93(\mathrm{~d}, J=1.2 \mathrm{~Hz}, 1 \mathrm{H}), 7.83-7.78(\mathrm{~m}, 3 \mathrm{H}), 7.52-7.44(\mathrm{~m}, 3 \mathrm{H}), 3.73(\mathrm{t}, J=4.8 \mathrm{~Hz}$, 4H), $3.01(\mathrm{t}, J=4.8 \mathrm{~Hz}, 4 \mathrm{H}) .{ }^{13} \mathrm{C}$ NMR $\left(100 \mathrm{MHz}, \mathrm{CDCl}_{3}\right) \delta 133.5,132.8,132.4$, 129.0, 128.3, 127.9, 127.8(2C), 126.6, 126.4, 67.8, 56.2. HRMS (ESI) calcd. for $\mathrm{C}_{14} \mathrm{H}_{16} \mathrm{NOS}[\mathrm{M}+\mathrm{H}]: 246.0947$, found: 246.0953 .

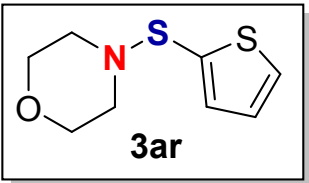

4-(Thiophen-2-ylthio)morpholine (3ar): The title compound was prepared according to the general procedure and purified by flash column chromatography on silica gel to give the light yellow oil, $86 \mathrm{mg}, 86 \%$ yield. ${ }^{1} \mathrm{H}$ NMR $\left(400 \mathrm{MHz}, \mathrm{CDCl}_{3}\right) \delta 7.49$ (dd, $J$ $=5.2 \mathrm{~Hz}, 1.2 \mathrm{~Hz}, 1 \mathrm{H}), 7.17(\mathrm{dd}, J=3.6 \mathrm{~Hz}, 1.2 \mathrm{~Hz}, 1 \mathrm{H}), 7.04(\mathrm{dd}, J=5.6 \mathrm{~Hz}, 3.6 \mathrm{~Hz}$, $1 \mathrm{H}), 3.61(\mathrm{t}, J=4.8 \mathrm{~Hz}, 4 \mathrm{H}), 2.76(\mathrm{t}, J=4.8 \mathrm{~Hz}, 4 \mathrm{H}) .{ }^{13} \mathrm{C} \mathrm{NMR}\left(100 \mathrm{MHz}, \mathrm{CDCl}_{3}\right) \delta$ 137.7, 132.9, 128.8, 127.8, 67.4, 55.1. HRMS (ESI) calcd. for $\mathrm{C}_{8} \mathrm{H}_{12} \mathrm{NOS}_{2}[\mathrm{M}+\mathrm{H}]$ : 202.0355, found: 202.0356 . 


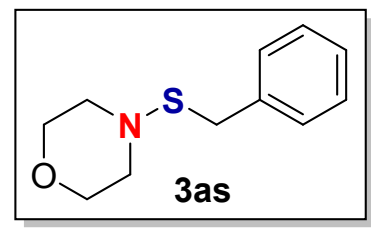

4-(Benzylthio)morpholine (3as) ${ }^{2}$ : The title compound was prepared according to the general procedure and purified by flash column chromatography on silica gel to give a white solid; $69.4 \mathrm{mg}, 66 \%$ yield. ${ }^{1} \mathrm{H}$ NMR $\left(400 \mathrm{MHz}, \mathrm{CDCl}_{3}\right) \delta 7.35-7.31(\mathrm{~m}, 2 \mathrm{H})$, 7.31-7.27 (m, 2H), 7.25-7.20 (m, 1H), $3.94(\mathrm{~s}, 2 \mathrm{H}), 3.62(\mathrm{t}, J=4.8 \mathrm{~Hz}, 4 \mathrm{H}), 2.95(\mathrm{t}, J=$ $4.8 \mathrm{~Hz}, 4 \mathrm{H}) .{ }^{13} \mathrm{C}$ NMR $\left(100 \mathrm{MHz}, \mathrm{CDCl}_{3}\right) \delta 137.6,129.3,128.5,126.9,67.7,56.3$, 36.9. HRMS (ESI) calcd. for $\mathrm{C}_{11} \mathrm{H}_{16} \mathrm{NOS}[\mathrm{M}+\mathrm{H}]: 210.0947$, found: 210.0955 .

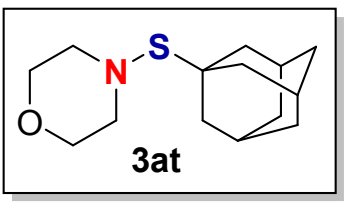

4-((3s,5s,7s)-Adamantan-1-yl)thio)morpholine (3at): The title compound was prepared according to the general procedure and purified by flash column chromatography on silica gel to give a white solid, $67.0 \mathrm{mg}, 53 \%$ yield. ${ }^{1} \mathrm{H}$ NMR (400 $\left.\mathrm{MHz}, \mathrm{CDCl}_{3}\right) \delta 3.61(\mathrm{t}, J=4.8 \mathrm{~Hz}, 4 \mathrm{H}), 2.87(\mathrm{t}, J=4.8 \mathrm{~Hz}, 4 \mathrm{H}), 1.96(\mathrm{~d}, J=14.0 \mathrm{~Hz}$, $3 \mathrm{H}), 1.74(\mathrm{~d}, J=2.4 \mathrm{~Hz}, 6 \mathrm{H}), 1.66-1.59(\mathrm{~m}, 6 \mathrm{H}) .{ }^{13} \mathrm{C} \mathrm{NMR}\left(100 \mathrm{MHz}, \mathrm{CDCl}_{3}\right) \delta 67.7$, 59.2, 49.9, 41.3, 36.5, 29.4. HRMS (ESI) calcd. for $\mathrm{C}_{14} \mathrm{H}_{24} \mathrm{NOS}[\mathrm{M}+\mathrm{H}]: 254.1573$, found: 254.1570 .

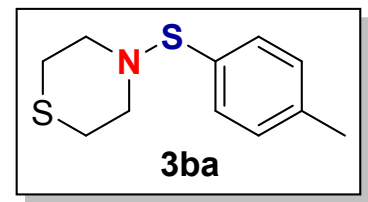

4-(p-Tolylthio)thiomorpholine (3ba): The title compound was prepared according to the general procedure and purified by flash column chromatography on silica gel to give a light yellow solid, $67 \mathrm{mg}, 60 \%$ yield. ${ }^{1} \mathrm{H} \mathrm{NMR}\left(400 \mathrm{MHz}, \mathrm{CDCl}_{3}\right) \delta 7.27(\mathrm{~d}, J=$ $8.0 \mathrm{~Hz}, 2 \mathrm{H}), 7.09$ (d, $J=8.0 \mathrm{~Hz}, 2 \mathrm{H}), 3.14$ (t, $J=4.8 \mathrm{~Hz}, 4 \mathrm{H}), 2.61$ (t, $J=4.8 \mathrm{~Hz}, 4 \mathrm{H})$, $2.28(\mathrm{~s}, 3 \mathrm{H}) .{ }^{13} \mathrm{C}$ NMR $\left(100 \mathrm{MHz}, \mathrm{CDCl}_{3}\right) \delta 138.5,131.7,130.8,129.5,58.3,28.8$, 21.2. HRMS (ESI) calcd. for $\mathrm{C}_{11} \mathrm{H}_{16} \mathrm{NS}_{2}[\mathrm{M}+\mathrm{H}]$ : 226.0719 , found: 226.0718 . 


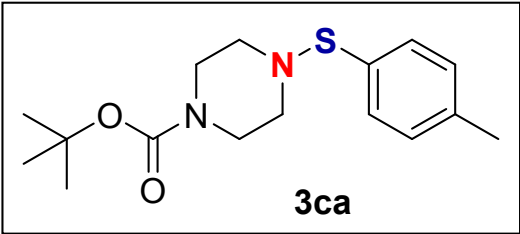

tert-Butyl 4-(p-tolylthio)piperazine-1-carboxylate (3ca): The title compound was prepared according to the general procedure and purified by flash column chromatography on silica gel to give the light yellow oil, $100 \mathrm{mg}, 65 \%$ yield. ${ }^{1} \mathrm{H}$ NMR $\left(400 \mathrm{MHz}, \mathrm{CDCl}_{3}\right) \delta 7.39(\mathrm{~d}, J=8.0 \mathrm{~Hz}, 2 \mathrm{H}), 7.18(\mathrm{~d}, J=8.0 \mathrm{~Hz}, 2 \mathrm{H}), 3.43(\mathrm{t}, J=4.8$ $\mathrm{Hz}, 4 \mathrm{H}), 2.83$ (t, $J=5.2 \mathrm{~Hz}, 4 \mathrm{H}), 2.37(\mathrm{~s}, 3 \mathrm{H}), 1.41$ (s, 9H). ${ }^{13} \mathrm{C}$ NMR $(100 \mathrm{MHz}$, $\left.\mathrm{CDCl}_{3}\right) \delta 154.5,139.1,133.4,129.5,129.0,79.8,55.6,44.7,28.4,21.3$. HRMS (ESI) calcd. for $\mathrm{C}_{16} \mathrm{H}_{25} \mathrm{~N}_{2} \mathrm{O}_{2} \mathrm{~S}$ [M+H]: 309.1631, found: 309.1623 .

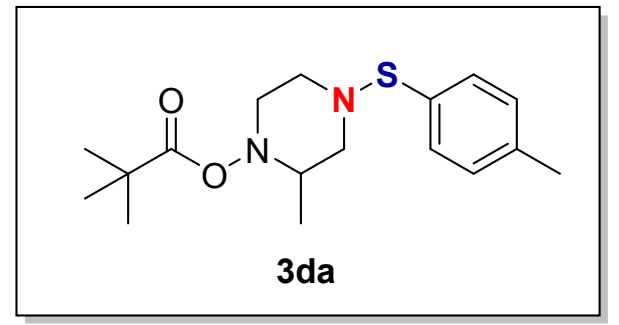

2-Methyl-4-(p-tolylthio)piperazin-1-yl pivalate (3da): The title compound was prepared according to the general procedure and purified by flash column chromatography on silica gel to give the light yellow oil, $124 \mathrm{mg}, 77 \%$ yield. ${ }^{1} \mathrm{H}$ NMR $\left(400 \mathrm{MHz}, \mathrm{CDCl}_{3}\right) \delta 7.37(\mathrm{~d}, J=8.0 \mathrm{~Hz}, 2 \mathrm{H}), 7.17(\mathrm{~d}, J=7.6 \mathrm{~Hz}, 2 \mathrm{H}), 4.20-4.13(\mathrm{~m}$, $1 \mathrm{H}), 3.78-3.74(\mathrm{~m}, 1 \mathrm{H}), 3.16(\mathrm{td}, J=12.4 \mathrm{~Hz}, 3.2 \mathrm{~Hz}, 1 \mathrm{H}), 3.10-3.05(\mathrm{~m}, 1 \mathrm{H})$, 2.96-2.92 (m, 1H), $2.74(\mathrm{dd}, J=11.6 \mathrm{~Hz}, 4.0 \mathrm{~Hz}, 1 \mathrm{H}), 2.60-2.53(\mathrm{~m}, 1 \mathrm{H}), 2.35(\mathrm{~s}, 3 \mathrm{H})$, $1.41(\mathrm{~s}, 9 \mathrm{H}), 1.27(\mathrm{~d}, J=6.8 \mathrm{~Hz}, 3 \mathrm{H}) .{ }^{13} \mathrm{C} \mathrm{NMR}\left(100 \mathrm{MHz}, \mathrm{CDCl}_{3}\right) \delta 154.4,139.0$, 133.2, 129.4, 129.1, 79.6, 60.3, 55.9, 47.6, 39.6, 28.4, 21.2, 15.6. HRMS (ESI) calcd. for $\mathrm{C}_{17} \mathrm{H}_{26} \mathrm{~N}_{2} \mathrm{O}_{2} \mathrm{SNa}$ [M+Na]: 345.1607, found: 345.1610 .<smiles>Cc1ccc(SN2CCN(C(=O)OCc3ccccc3)CC2)cc1</smiles>

Benzyl-4-(p-tolylthio)piperazine-1-carboxylate (3ea): The title compound was prepared according to the general procedure and purified by flash column 
chromatography on silica gel to give the light yellow oil, $124 \mathrm{mg}, 73 \%$ yield. ${ }^{1} \mathrm{H}$ NMR $\left(400 \mathrm{MHz}, \mathrm{CDCl}_{3}\right) \delta 7.44(\mathrm{~m}, 2 \mathrm{H}), 7.38-7.25(\mathrm{~m}, 5 \mathrm{H}), 7.16(\mathrm{~d}, J=7.6 \mathrm{~Hz}, 2 \mathrm{H}), 5.06(\mathrm{~s}$, 2H), $3.51(\mathrm{t}, J=4.8 \mathrm{~Hz}, 4 \mathrm{H}), 2.83(\mathrm{~s}, 4 \mathrm{H}), 2.35(\mathrm{~s}, 3 \mathrm{H}) \cdot{ }^{13} \mathrm{C} \mathrm{NMR}\left(100 \mathrm{MHz}, \mathrm{CDCl}_{3}\right) \delta$ $155.0,139.2,136.6,133.5,129.5,128.8,128.5,128.1,128.0,67.2,55.5,44.6,21.3$. HRMS (ESI) calcd. for $\mathrm{C}_{19} \mathrm{H}_{22} \mathrm{~N}_{2} \mathrm{NaO}_{2} \mathrm{~S}$ [M+Na]: 365.1294, found: 365.1284 .

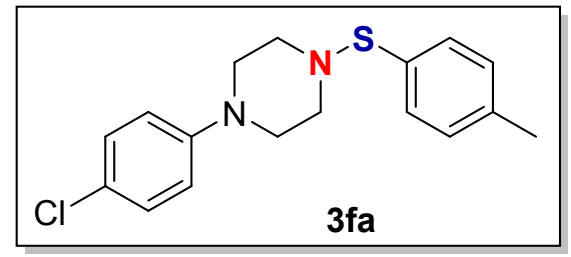

1-(4-Chlorophenyl)-4-(p-tolylthio)piperazine (3fa): The title compound was prepared according to the general procedure and purified by flash column chromatography on silica gel to give a white solid, $64.3 \mathrm{mg}, 40 \%$ yield. ${ }^{1} \mathrm{H}$ NMR (400 $\left.\mathrm{MHz}, \mathrm{CDCl}_{3}\right) \delta 7.35(\mathrm{~d}, J=8.0 \mathrm{~Hz}, 2 \mathrm{H}), 7.12-7.06(\mathrm{~m}, 4 \mathrm{H}), 6.71-6.66(\mathrm{~m}, 2 \mathrm{H})$, 3.08-3.05 (m, 4H), 2.97-2.94 (m, 4H), $2.28(\mathrm{~s}, 3 \mathrm{H}) .{ }^{13} \mathrm{C}$ NMR (100 MHz, $\left.\mathrm{CDCl}_{3}\right) \delta$ 149.7, 138.9, 133.1, 129.4, 128.9, 124.8, 117.5, 117.5, 55.5, 50.3, 21.3. HRMS (ESI) calcd. for $\mathrm{C}_{17} \mathrm{H}_{20} \mathrm{ClN}_{2} \mathrm{~S}[\mathrm{M}+\mathrm{H}]: 319.1030$, found: 319.1024 .

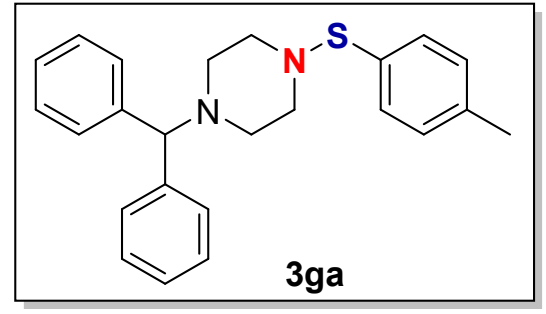

1-Benzhydryl-4-(p-tolylthio)piperazine (3ga): The title compound was prepared according to the general procedure and purified by flash column chromatography on silica gel to give a light yellow solid, $96.2 \mathrm{mg}, 51 \%$ yield. ${ }^{1} \mathrm{H}$ NMR (400 $\mathrm{MHz}, \mathrm{CDCl}_{3}$ ) $\delta 7.39(\mathrm{~d}, J=8.0 \mathrm{~Hz}, 2 \mathrm{H}), 7.33(\mathrm{~d}, J=8.8 \mathrm{~Hz}, 4 \mathrm{H}), 7.22-7.11(\mathrm{~m}, 8 \mathrm{H}), 4.15(\mathrm{~s}, 1 \mathrm{H})$, $2.91(\mathrm{t}, J=4.8 \mathrm{~Hz}, 4 \mathrm{H}), 2.41(\mathrm{t}, J=4.8 \mathrm{~Hz}, 4 \mathrm{H}), 2.36(\mathrm{~s}, 3 \mathrm{H}) .{ }^{13} \mathrm{C} \mathrm{NMR}(100 \mathrm{MHz}$, $\left.\mathrm{CDCl}_{3}\right) \delta 142.7,138.8,133.3,129.6,129.5,128.6,127.9,127.0,76.2,56.1,53.0,21.4$. HRMS (ESI) calcd. for $\mathrm{C}_{24} \mathrm{H}_{27} \mathrm{~N}_{2} \mathrm{~S}$ [M+H]: 375.1889, found: 375.1887 . 


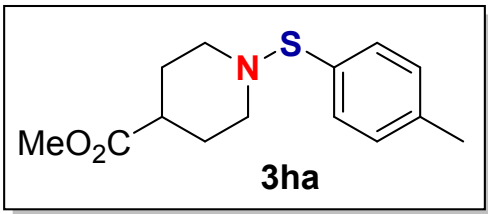

Methyl 1-(p-tolylthio)piperidine-4-carboxylate (3ha): The title compound was prepared according to the general procedure and purified by flash column chromatography on silica gel to give the light yellow oil, $92.9 \mathrm{mg}, 70 \%$ yield. ${ }^{1} \mathrm{H}$ NMR $\left(400 \mathrm{MHz}, \mathrm{CDCl}_{3}\right) \delta 7.37(\mathrm{~d}, J=7.6 \mathrm{~Hz}, 2 \mathrm{H}), 7.16(\mathrm{~d}, J=8.0 \mathrm{~Hz}, 2 \mathrm{H}), 3.65(\mathrm{~s}, 3 \mathrm{H})$, 3.24-3.19 (m, 2H), 2.67-2.60 (m, 2H), $2.36(\mathrm{~s}, 3 \mathrm{H}), 2.17-2.09(\mathrm{~m}, 1 \mathrm{H}), 1.90-1.80(\mathrm{~m}$, 4H). ${ }^{13} \mathrm{C} \mathrm{NMR}\left(100 \mathrm{MHz}, \mathrm{CDCl}_{3}\right) \delta 175.2,138.3,136.5,131.9,129.3,55.8,51.6,39.8$, 29.5, 21.2. HRMS (ESI) calcd. for $\mathrm{C}_{14} \mathrm{H}_{20} \mathrm{NO}_{2} \mathrm{~S}$ [M+H]: 266.1209, found: 266.1209.

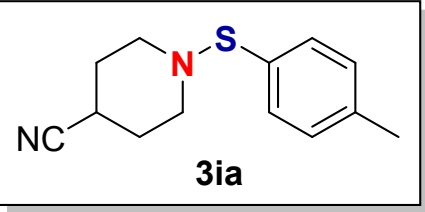

1-(p-Tolylthio)piperidine-4-carbonitrile (3ia): The title compound was prepared according to the general procedure and purified by flash column chromatography on silica gel to give the light yellow solid, $87.1 \mathrm{mg}, 75 \%$ yield. ${ }^{1} \mathrm{H}$ NMR (400 MHz, $\left.\mathrm{CDCl}_{3}\right) \delta 7.36(\mathrm{~d}, J=8.0 \mathrm{~Hz}, 2 \mathrm{H}), 7.17(\mathrm{~d}, J=8.0 \mathrm{~Hz}, 2 \mathrm{H}), 3.15-3.09(\mathrm{~m}, 2 \mathrm{H})$, 2.82-2.76 (m, 2H), 2.60-2.45 (m, 1H), $2.36(\mathrm{~s}, 3 \mathrm{H}), 2.06-1.73(\mathrm{~m}, 4 \mathrm{H}) .{ }^{13} \mathrm{C}$ NMR $(100$ $\left.\mathrm{MHz}, \mathrm{CDCl}_{3}\right) \delta 139.8,132.5,129.5,129.5,121.3,54.4,29.9,25.0,21.2$. HRMS (ESI) calcd. for $\mathrm{C}_{13} \mathrm{H}_{17} \mathrm{~N}_{2} \mathrm{~S}[\mathrm{M}+\mathrm{H}]$ : 233.1107, found: 233.1106 .

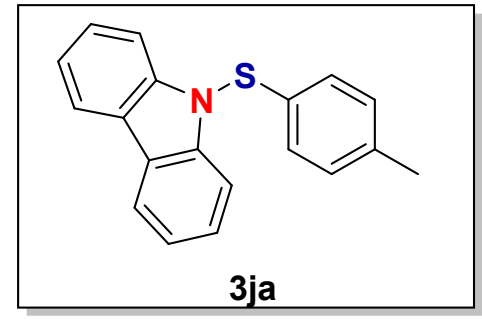

9-(p-Tolylthio)-9H-carbazole (3ja): The title compound was prepared according to the general procedure and purified by flash column chromatography on silica gel to give a white solid, $44.8 \mathrm{mg}, 30 \%$ yield. ${ }^{1} \mathrm{H}$ NMR (400 MHz, $\left.\mathrm{CDCl}_{3}\right) \delta 7.98(\mathrm{~d}, J=7.6$ $\mathrm{Hz}, 2 \mathrm{H}), 7.69(\mathrm{~d}, J=8.0 \mathrm{~Hz}, 2 \mathrm{H}), 7.42-7.37(\mathrm{~m}, 2 \mathrm{H}), 7.25-7.21(\mathrm{~m}, 2 \mathrm{H}), 6.91(\mathrm{~d}, J=$ 
$2.0 \mathrm{~Hz}, 4 \mathrm{H}), 2.16(\mathrm{~s}, 3 \mathrm{H}) .{ }^{13} \mathrm{C} \mathrm{NMR}\left(100 \mathrm{MHz}, \mathrm{CDCl}_{3}\right) \delta 143.4,137.2,134.2,129.9$, 126.5, 125.4, 124.6, 121.2, 120.2, 111.1, 21.0. HRMS (ESI) calcd. for $\mathrm{C}_{19} \mathrm{H}_{16} \mathrm{NS}$ [M+H]: 290.0998, found: 290.1002.

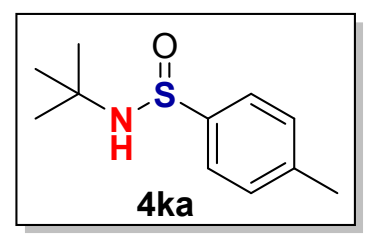

$N$-(tert-butyl)-S-(p-tolyl)thiohydroxylamine (4ka) ${ }^{1}$ : The title compound was prepared according to the general procedure and purified by column chromatography on silica gel to give a yellow solid, $74.1 \mathrm{mg}, 70 \%$ yield. ${ }^{1} \mathrm{H} \mathrm{NMR}\left(400 \mathrm{MHz}, \mathrm{CDCl}_{3}\right) \delta$ $7.56(\mathrm{~d}, J=8.4 \mathrm{~Hz}, 2 \mathrm{H}), 7.27$ (d, $J=8.0 \mathrm{~Hz}, 2 \mathrm{H}), 3.87$ (br, 1H), 2.40 (s, 3H), 1.40 (s, 9H). ${ }^{13} \mathrm{C}$ NMR $\left(100 \mathrm{MHz}, \mathrm{CDCl}_{3}\right) \delta 143.5,140.9,129.4,125.6,54.2,31.1,21.3$. HRMS (ESI) calcd. for $\mathrm{C}_{11} \mathrm{H}_{18} \mathrm{NOS}$ [M+H]: 212.1104, found: 212.1110.

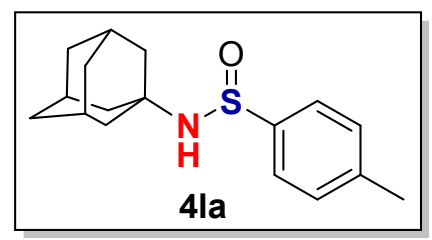

$N$-((3s,5s,7s)-adamantan-1-yl)-4-methylbenzenesulfinamide (4la): The title compound was prepared according to the general procedure and purified by column chromatography on silica gel to give a white compound was prepared according to the general procedure and purified by flash column chromatography on silica gel to give a white solid, $82.3 \mathrm{mg}, 57 \%$ yield. ${ }^{1} \mathrm{H}$ NMR (400 MHz, $\left.\mathrm{CDCl}_{3}\right) \delta 7.50(\mathrm{~d}, J=8.4 \mathrm{~Hz}$, 2H), $7.20(\mathrm{~d}, J=8.0 \mathrm{~Hz}, 2 \mathrm{H}), 3.78$ (br, 1H), 2.33 (s, 3H), 2.09-2.05 (m, 3H), 1.94-1.89 $(\mathrm{m}, 3 \mathrm{H}), 1.85-1.81(\mathrm{~m}, 3 \mathrm{H}), 1.66-1.58(\mathrm{~m}, 6 \mathrm{H}) .{ }^{13} \mathrm{C} \mathrm{NMR}\left(100 \mathrm{MHz}, \mathrm{CDCl}_{3}\right) \delta 143.7$, 140.9, 129.4, 125.7, 54.4, 44.7, 36.1, 29.7, 21.3. HRMS (ESI) calcd. for $\mathrm{C}_{17} \mathrm{H}_{24} \mathrm{NOS}$ [M+H]: 290.1573, found: 290.1568 .

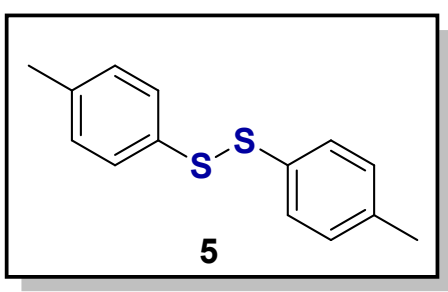

p-Tolyl disulfide (5) ${ }^{1}:{ }^{1} \mathrm{H}$ NMR $\left(400 \mathrm{MHz}, \mathrm{CDCl}_{3}\right) \delta 7.37$ (d, $\left.J=8.0 \mathrm{~Hz}, 4 \mathrm{H}\right), 7.09$ (d, 
$J=8.0 \mathrm{~Hz}, 4 \mathrm{H}), 2.30(\mathrm{~s}, 6 \mathrm{H}) .{ }^{13} \mathrm{C} \mathrm{NMR}\left(100 \mathrm{MHz}, \mathrm{CDCl}_{3}\right) \delta 137.5,133.9,129.8$, 128.6, 21.1.

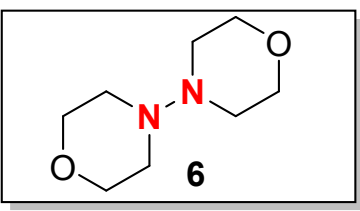

Diamine (6) ${ }^{4}:{ }^{1} \mathrm{H}$ NMR (400 MHz, $\left.\mathrm{CDCl}_{3}\right) \delta 3.74(\mathrm{t}, J=4.4 \mathrm{~Hz}, 8 \mathrm{H}), 2.76(\mathrm{t}, J=4.4$ $\mathrm{Hz}, 8 \mathrm{H}) .{ }^{13} \mathrm{C} \mathrm{NMR}\left(100 \mathrm{MHz}, \mathrm{CDCl}_{3}\right) \delta 67.4,48.6$.

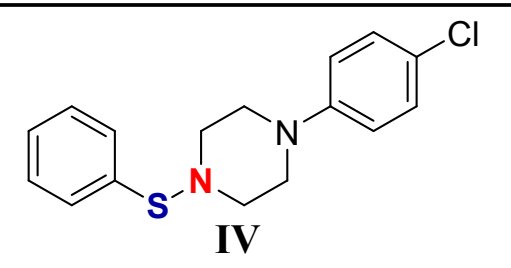

1-(4-Chlorophenyl)-4-(phenylthio)piperazine (IV) ${ }^{5}$ : The title compound was prepared according to the general procedure and purified by flash column chromatography on silica gel to give a white solid, $97.3 \mathrm{mg}, 64 \%$ yield. ${ }^{1} \mathrm{H}$ NMR (400 $\left.\mathrm{MHz}, \mathrm{CDCl}_{3}\right) \delta 7.38(\mathrm{~d}, J=7.2 \mathrm{~Hz}, 2 \mathrm{H}), 7.26(\mathrm{t}, J=8.0 \mathrm{~Hz}, 2 \mathrm{H}), 7.19(\mathrm{~d}, J=7.2 \mathrm{~Hz}$, 1H), $7.08(\mathrm{~d}, J=8.8 \mathrm{~Hz}, 2 \mathrm{H}), 6.68$ (d, $J=8.8 \mathrm{~Hz}, 2 \mathrm{H}), 3.07-3.05$ (m, 4H), 3.02-2.99 $(\mathrm{m}, 4 \mathrm{H}) .{ }^{13} \mathrm{C} \mathrm{NMR}\left(100 \mathrm{MHz}, \mathrm{CDCl}_{3}\right) \delta 149.8,134.8,130.5,129.0,128.8,127.9$, 124.9, 117.6, 55.8, 50.4. 


\section{References}

1. Taniguchi, N. Tetrahedron 2017, 73, 2030.

2. Yakan, H.; Kütük, H. Monatsh. Chem. 2018, 149, 2047.

3. Masao, S.; Yoshinori, S.; Takeo, K.; Yasuo, G.; Isao, S. Tetrahedron 2002, 58, 3779 .

4. Jackisch, J.; Legler, J.; Kauffmann, T. Chem. Ber. 1982, 115, 659.

5. Wilker, J. C.; Woodward, D. L. J. Med. Chem. 1980, 23, 677. 


\section{Copies for NMR of products}

LSP-X181213-4HNMR

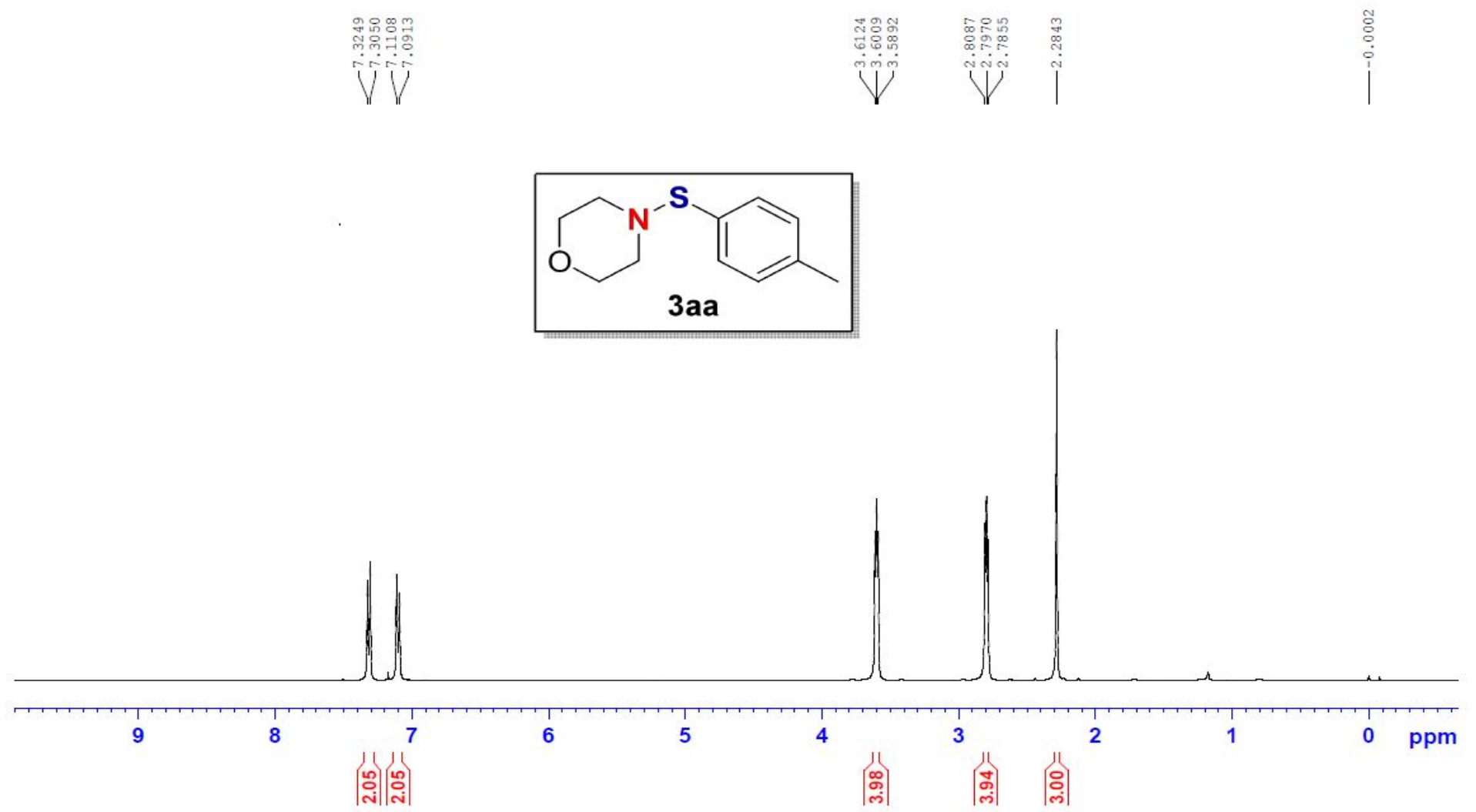


LSP-X181213-4CNMR

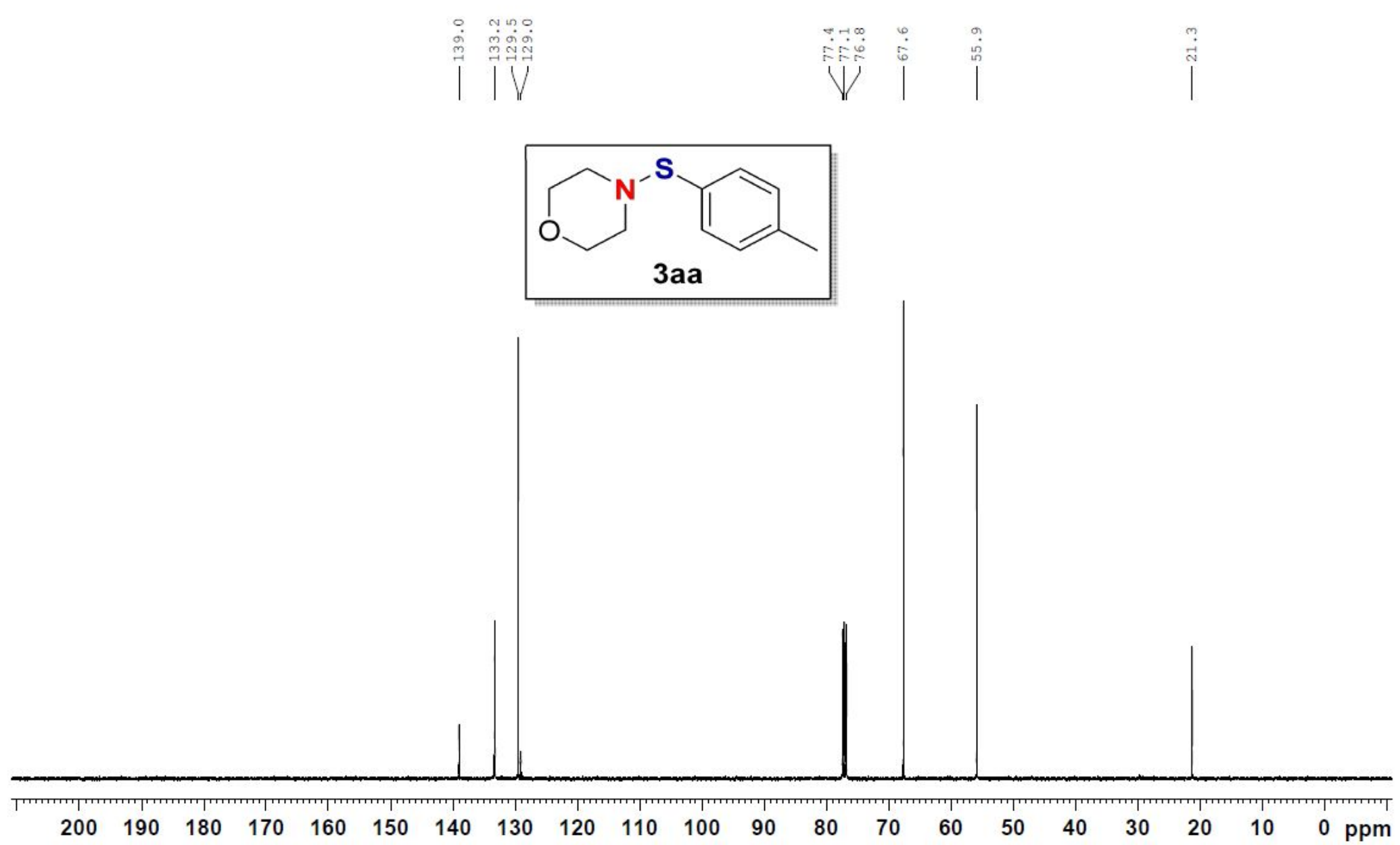




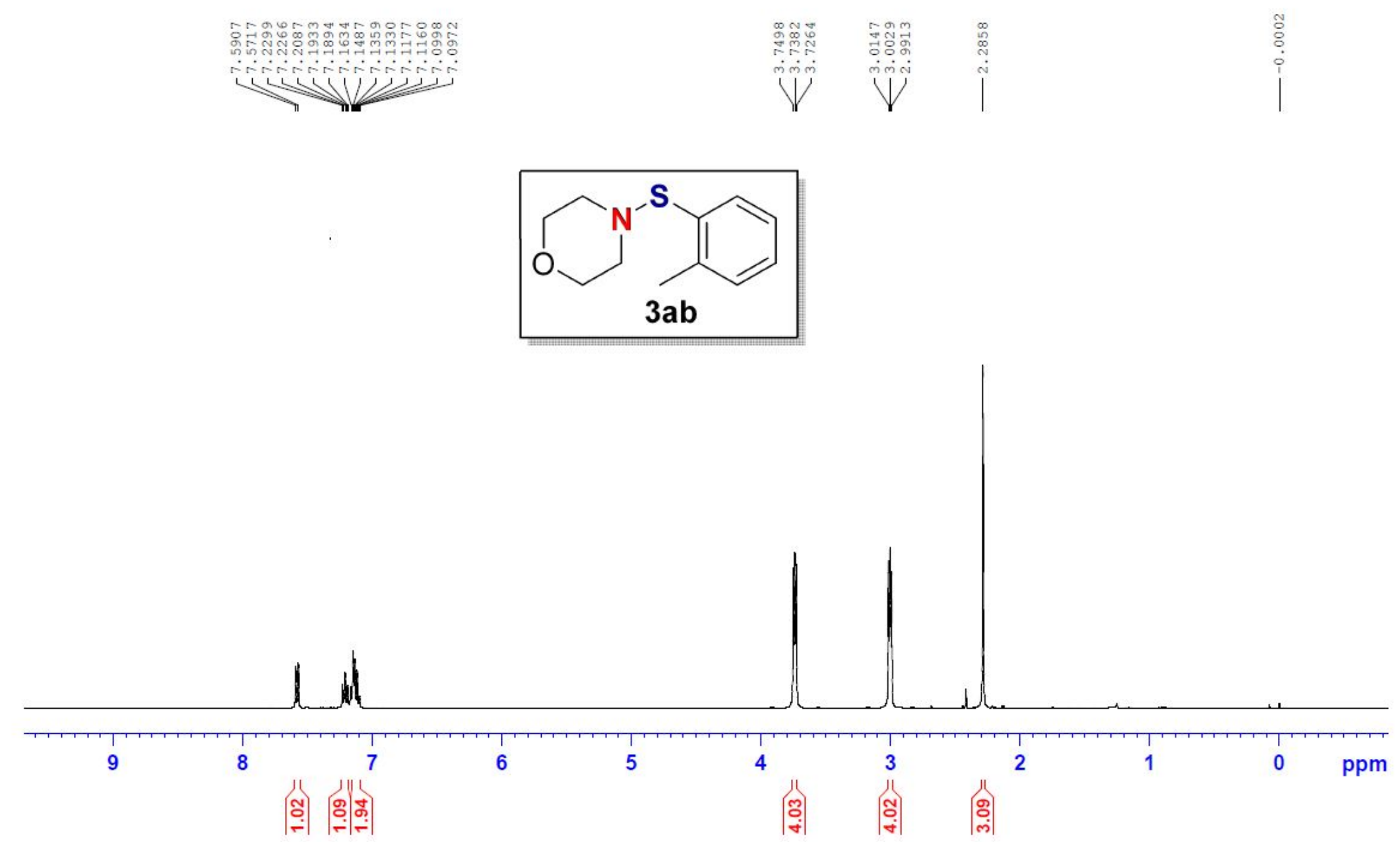



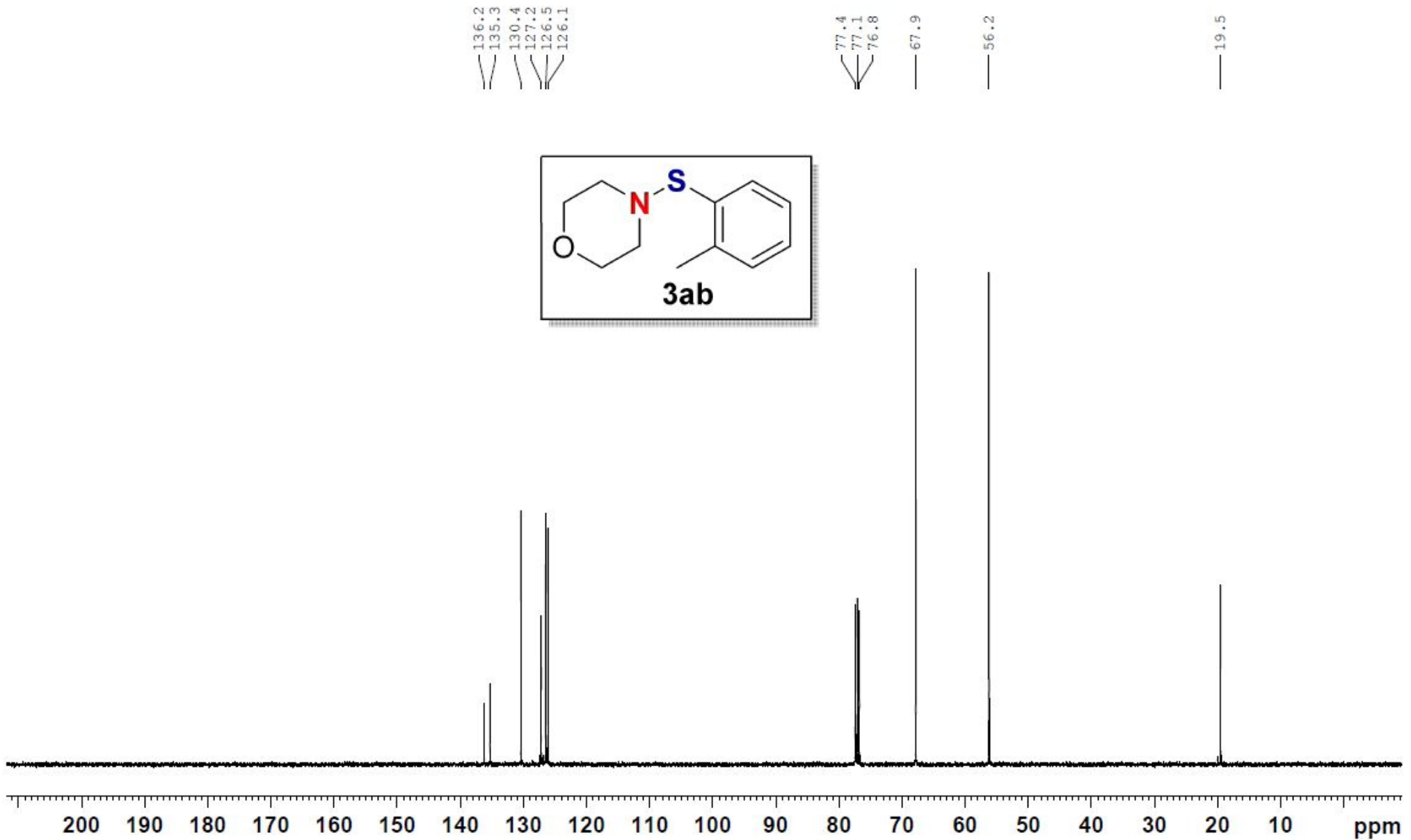
LSP-X181219-2HNMR

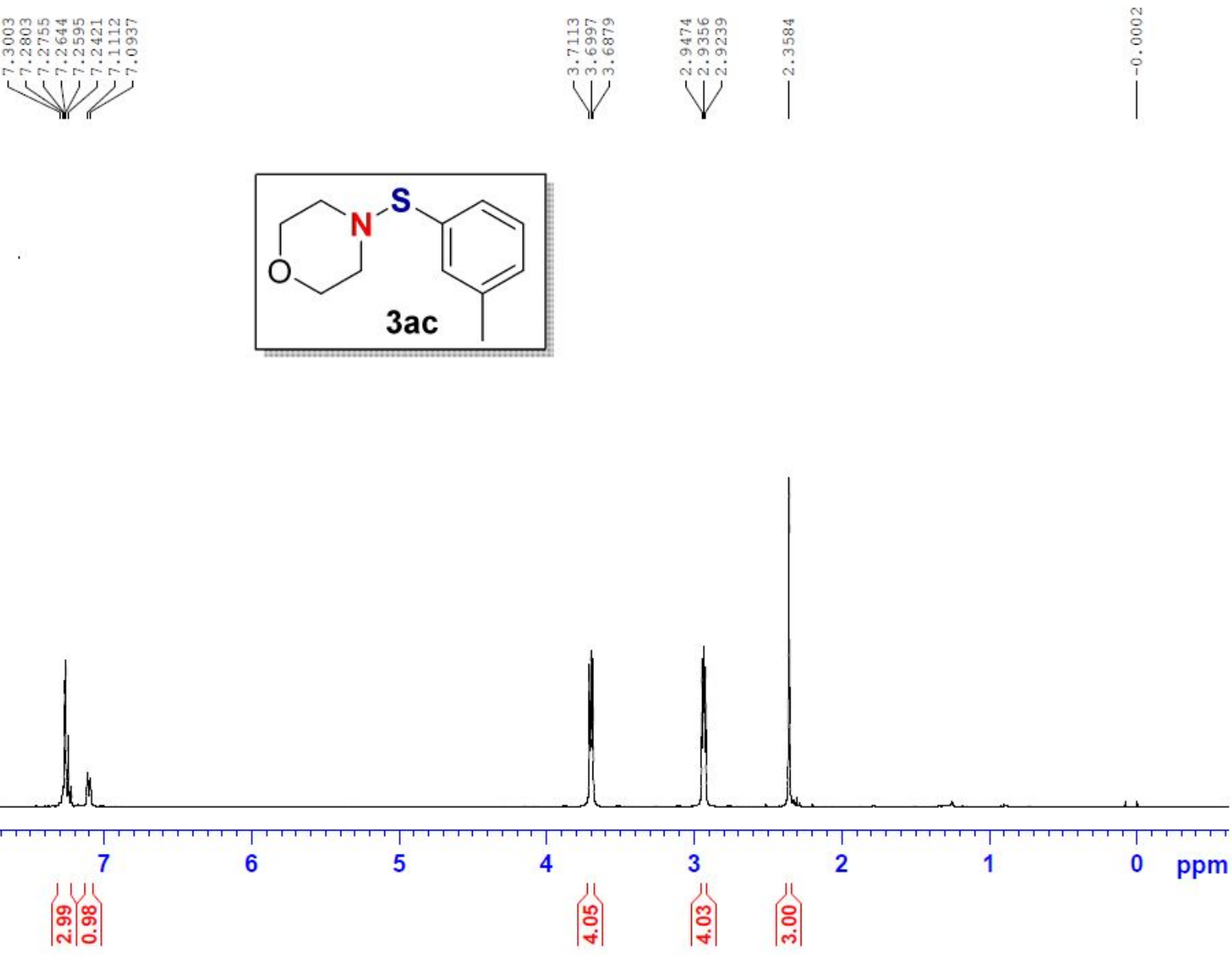




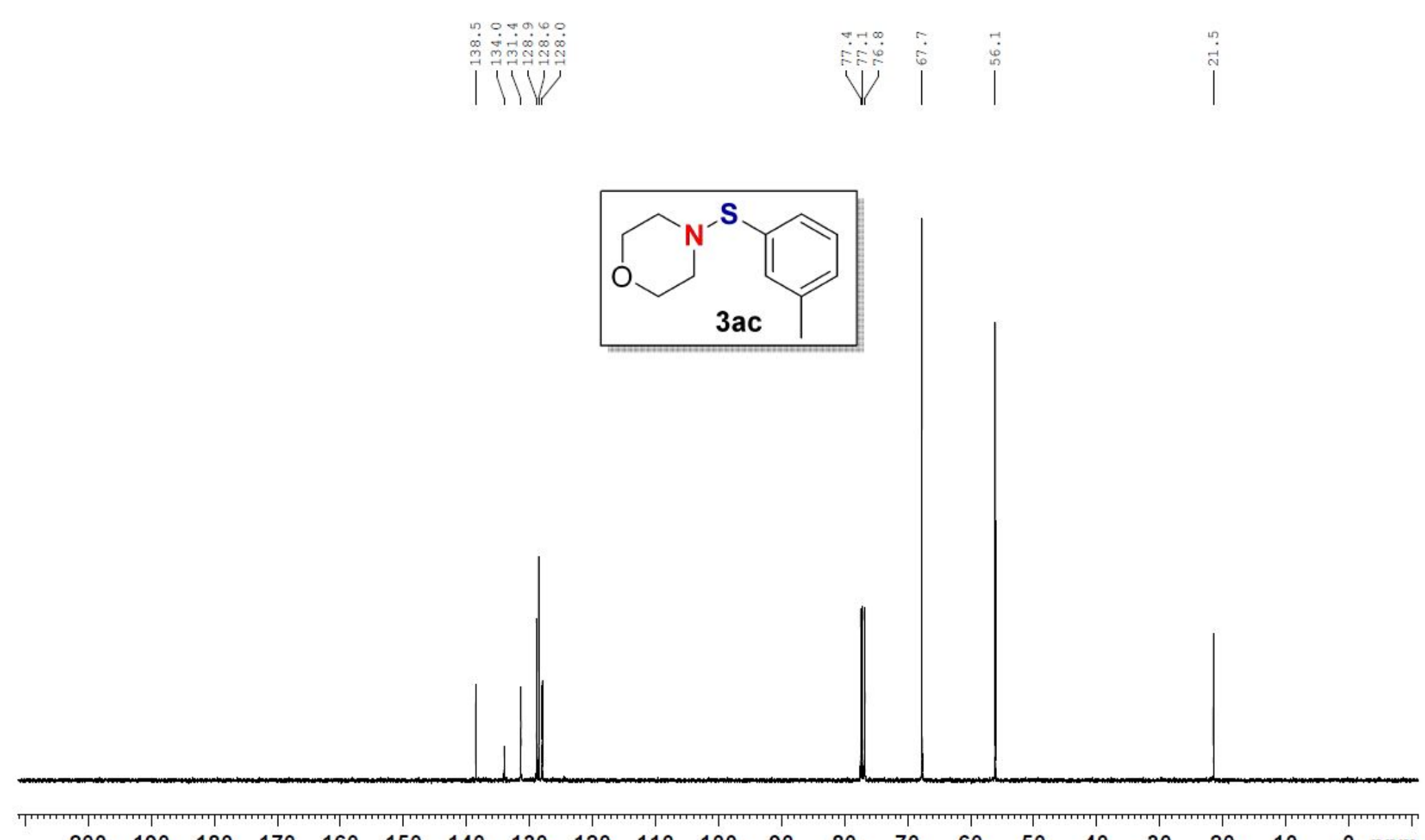

$\begin{array}{llllllllllllllllllllllll}200 & 190 & 180 & 170 & 160 & 150 & 140 & 130 & 120 & 110 & 100 & 90 & 80 & 70 & 60 & 50 & 40 & 30 & 20 & 10 & 0 & \mathrm{ppm}\end{array}$ 
LSP-X181227-2HNMR
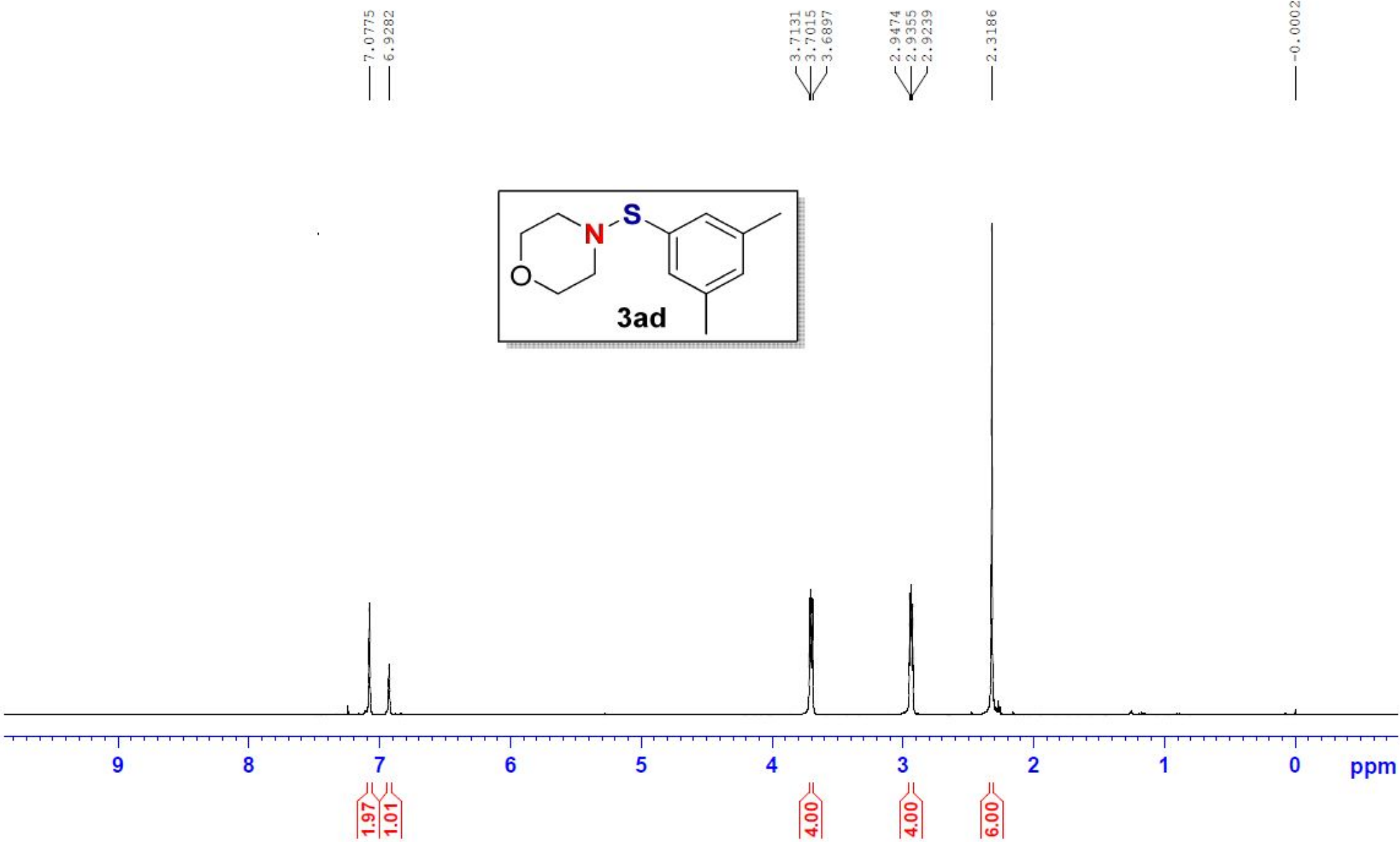

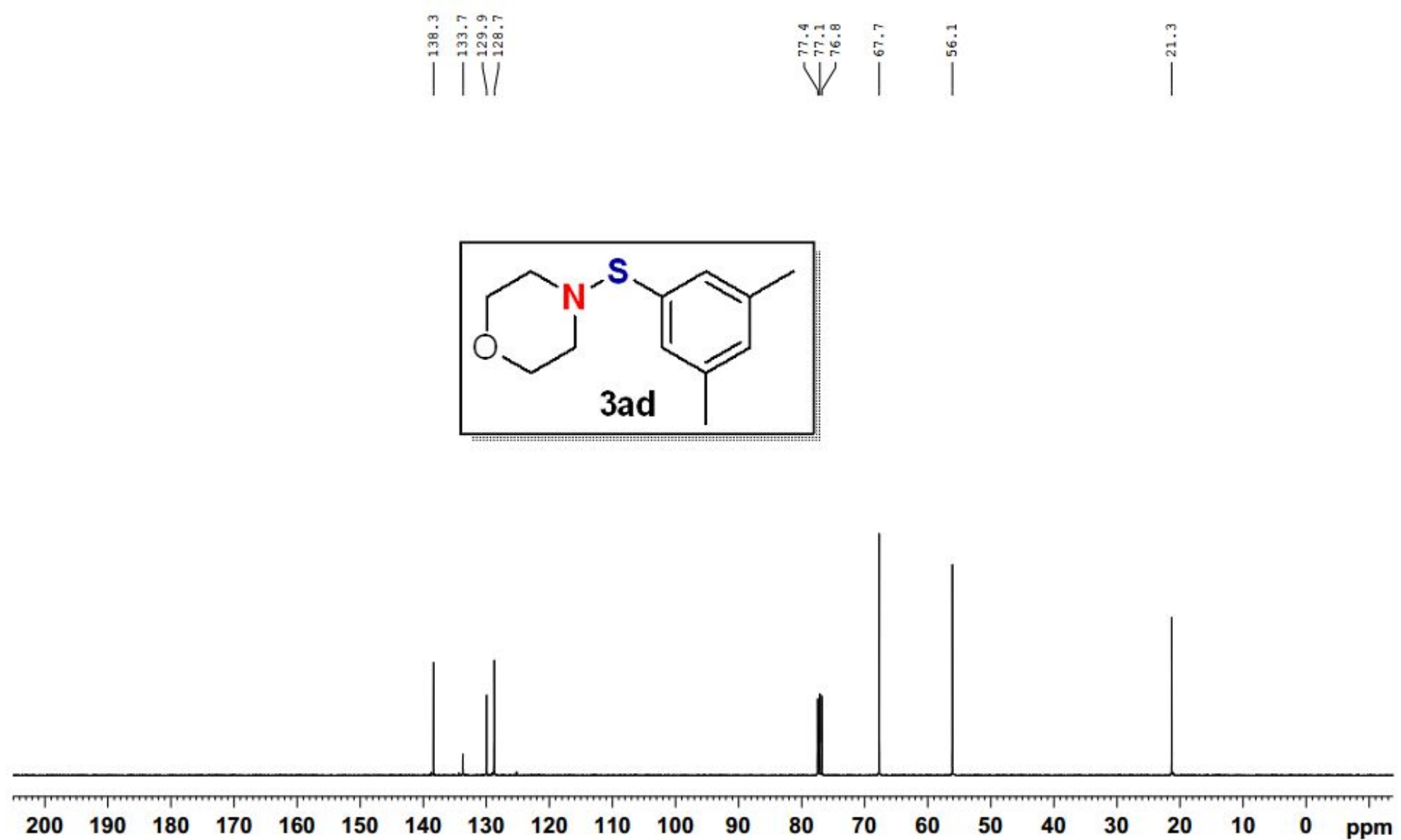
LSP-X181226-2HNMR

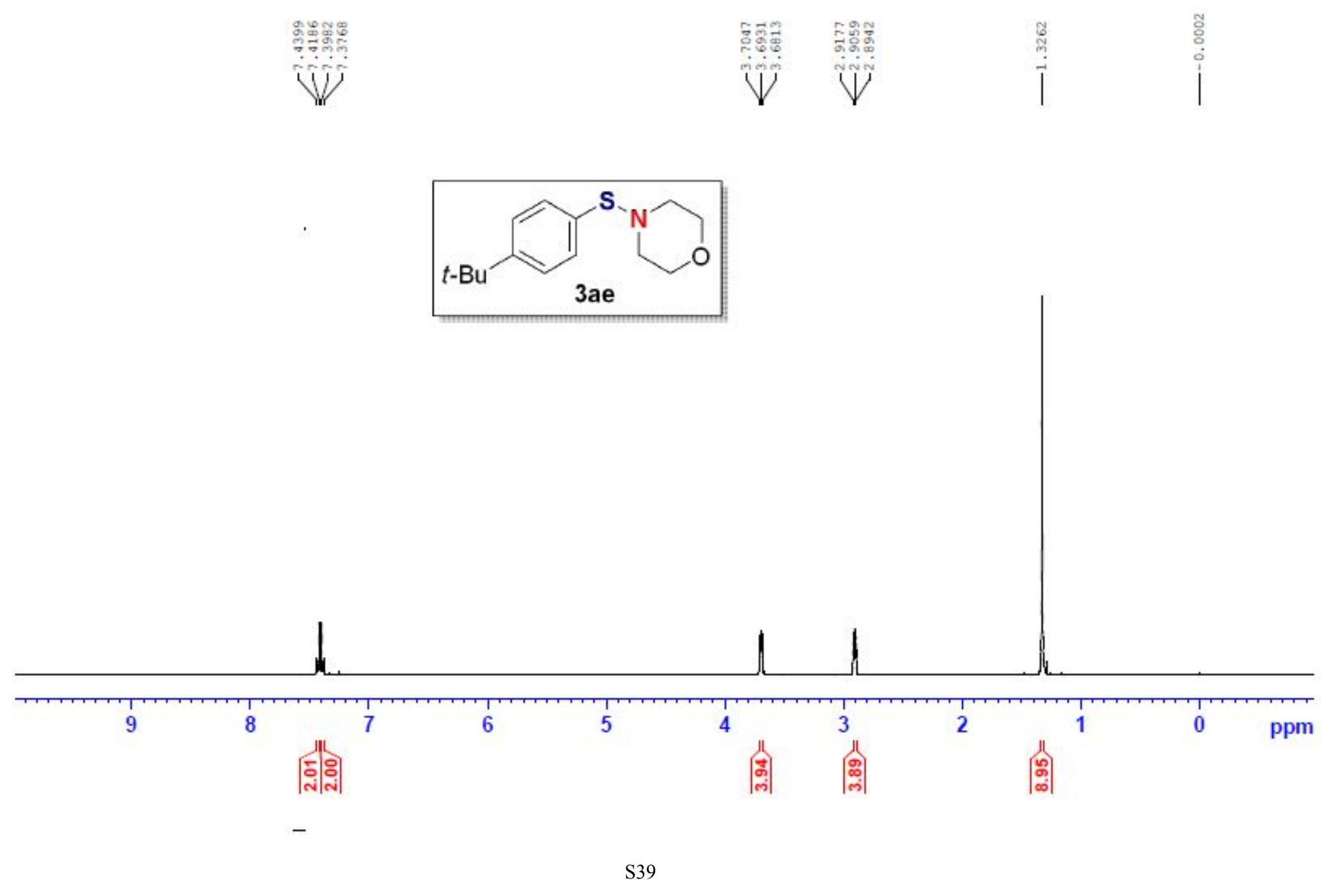


LSP-X1 81226-2CNMR
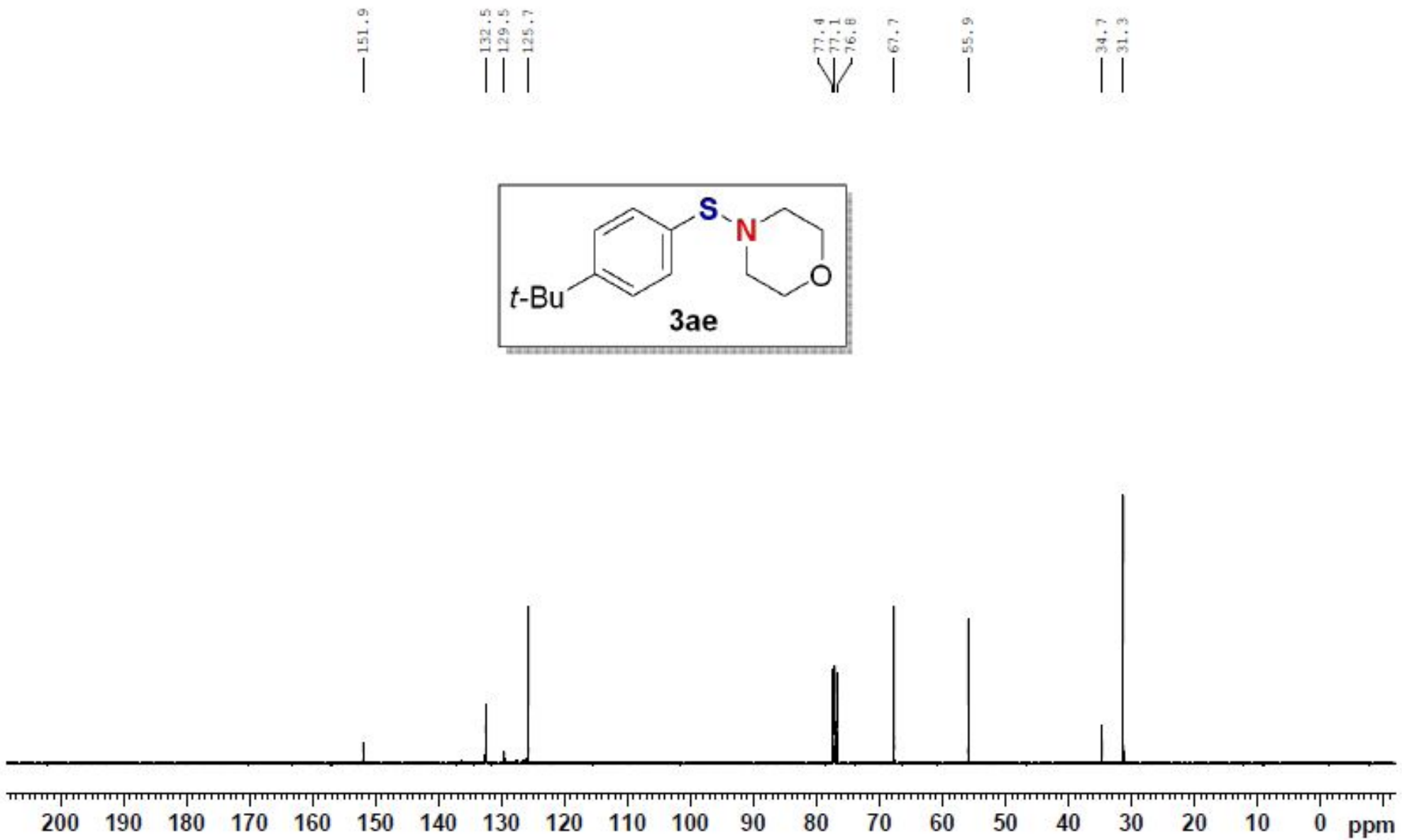
LSP-X181227-1HNMR
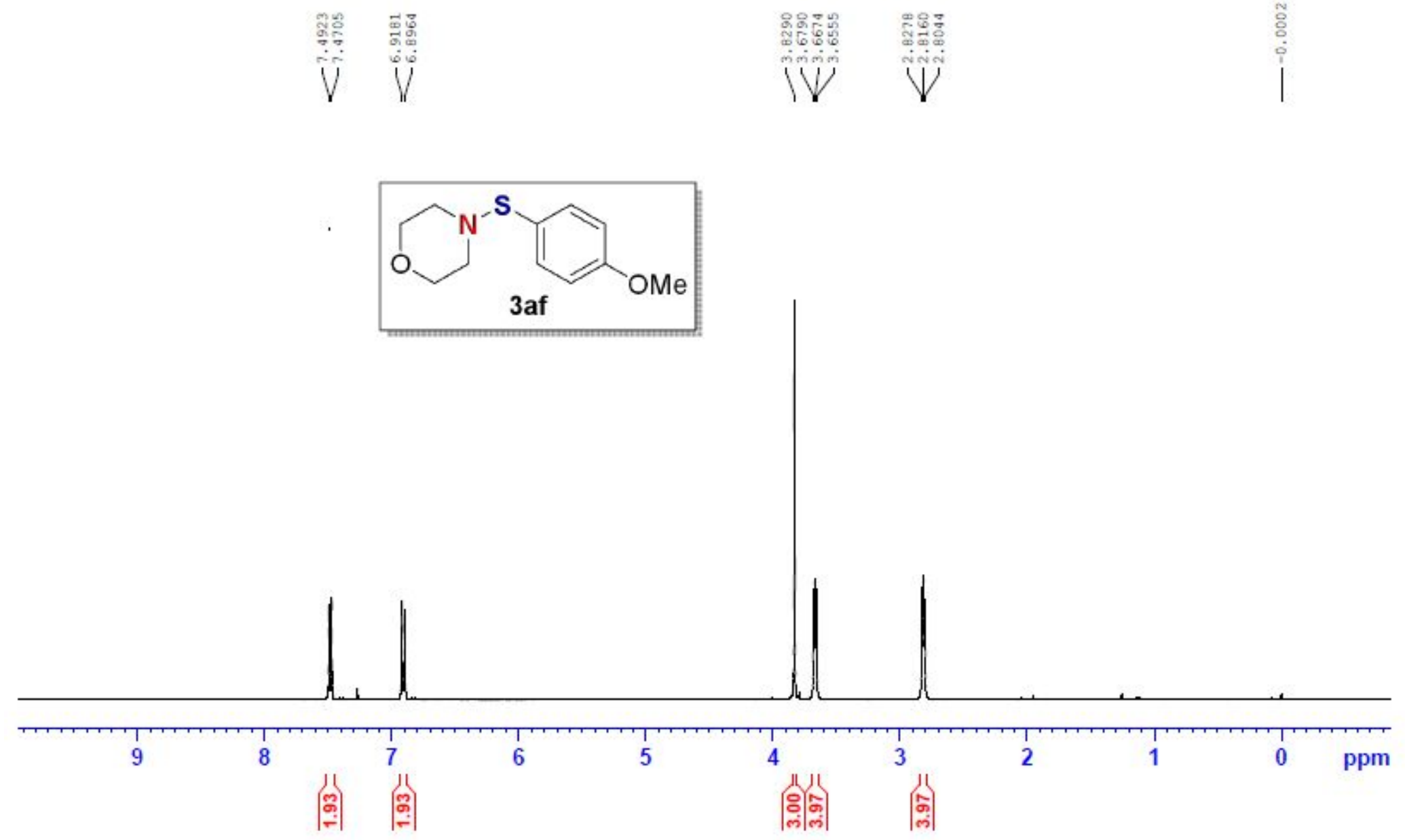

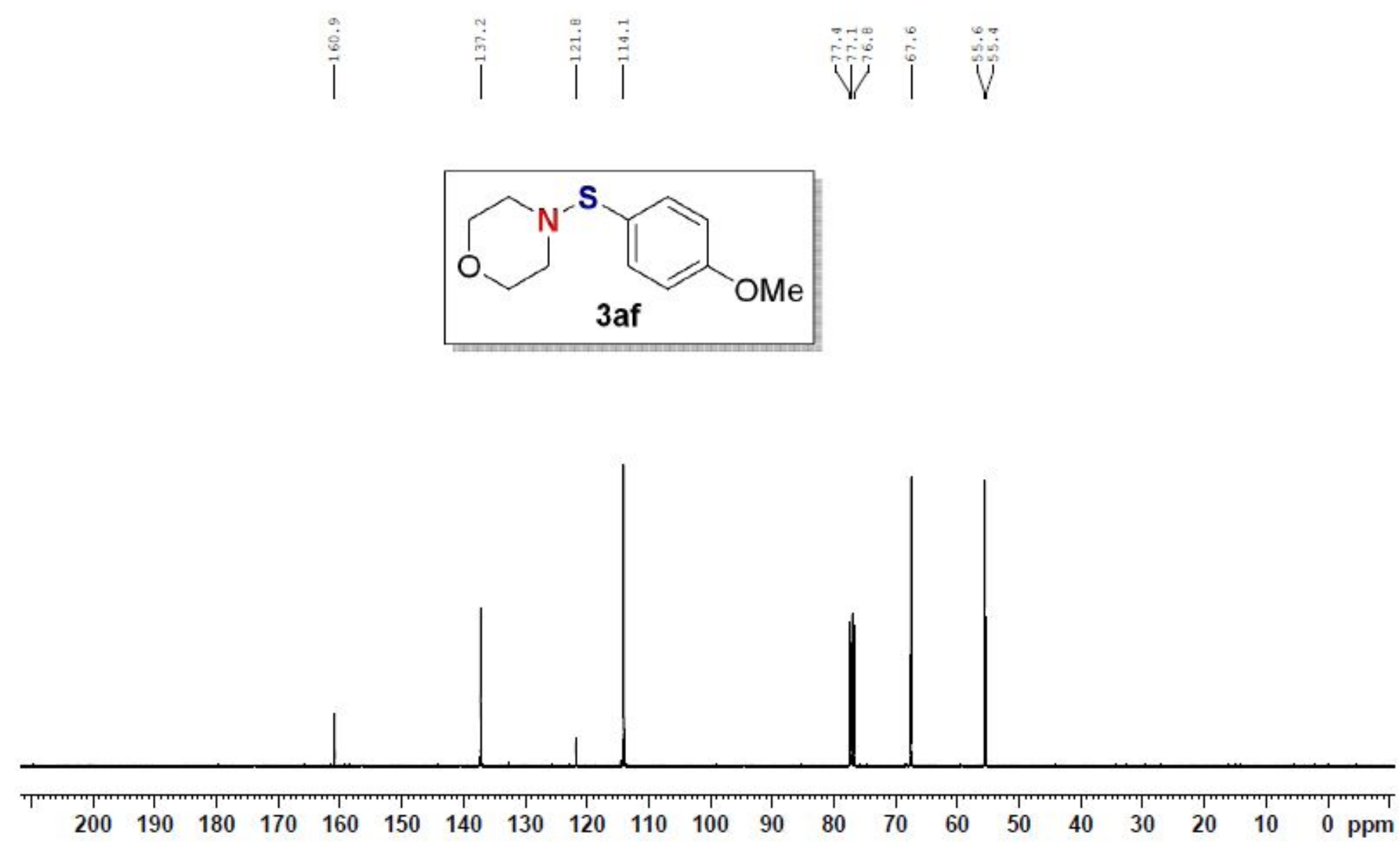
LSP-X190107-3HNMR
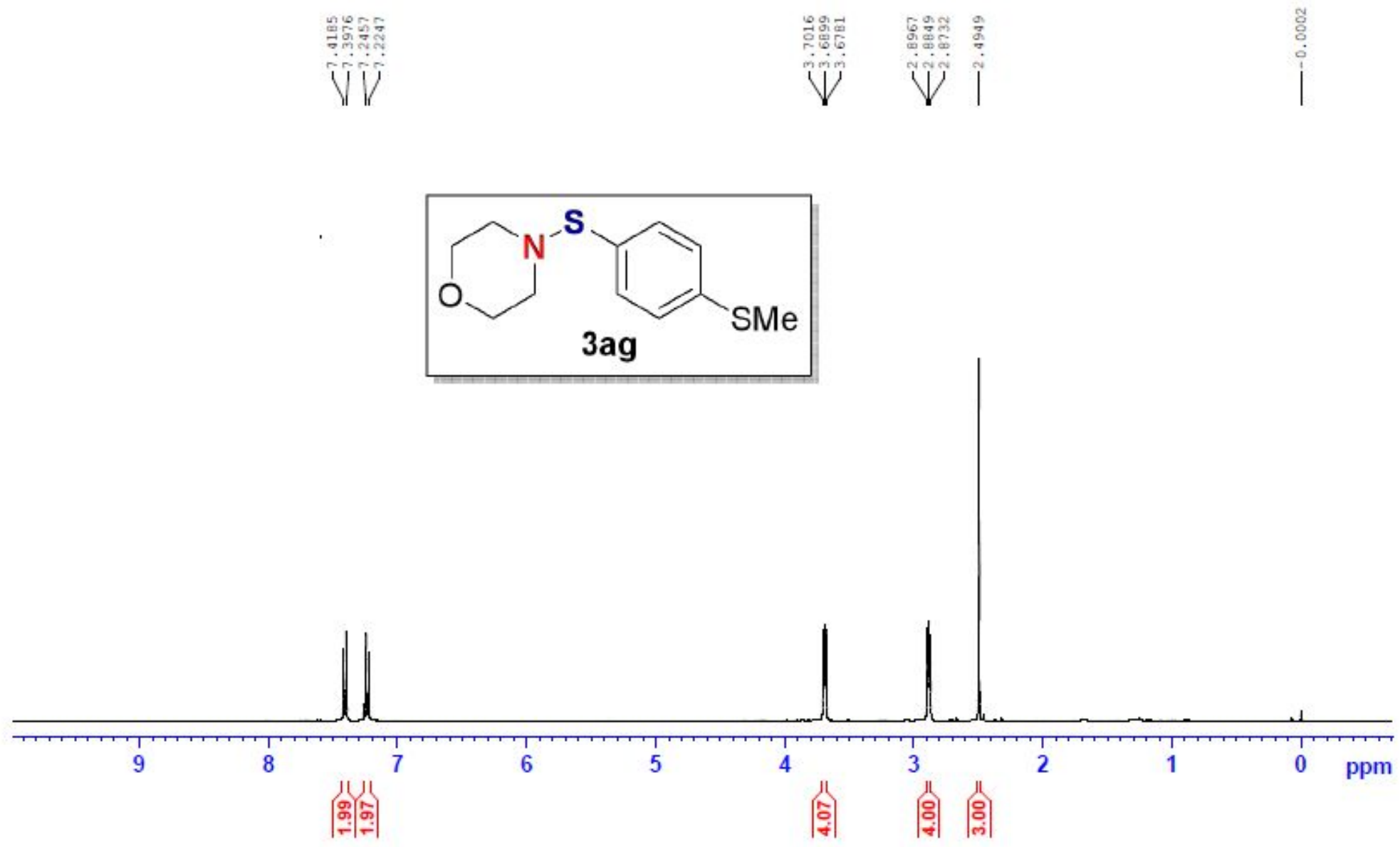

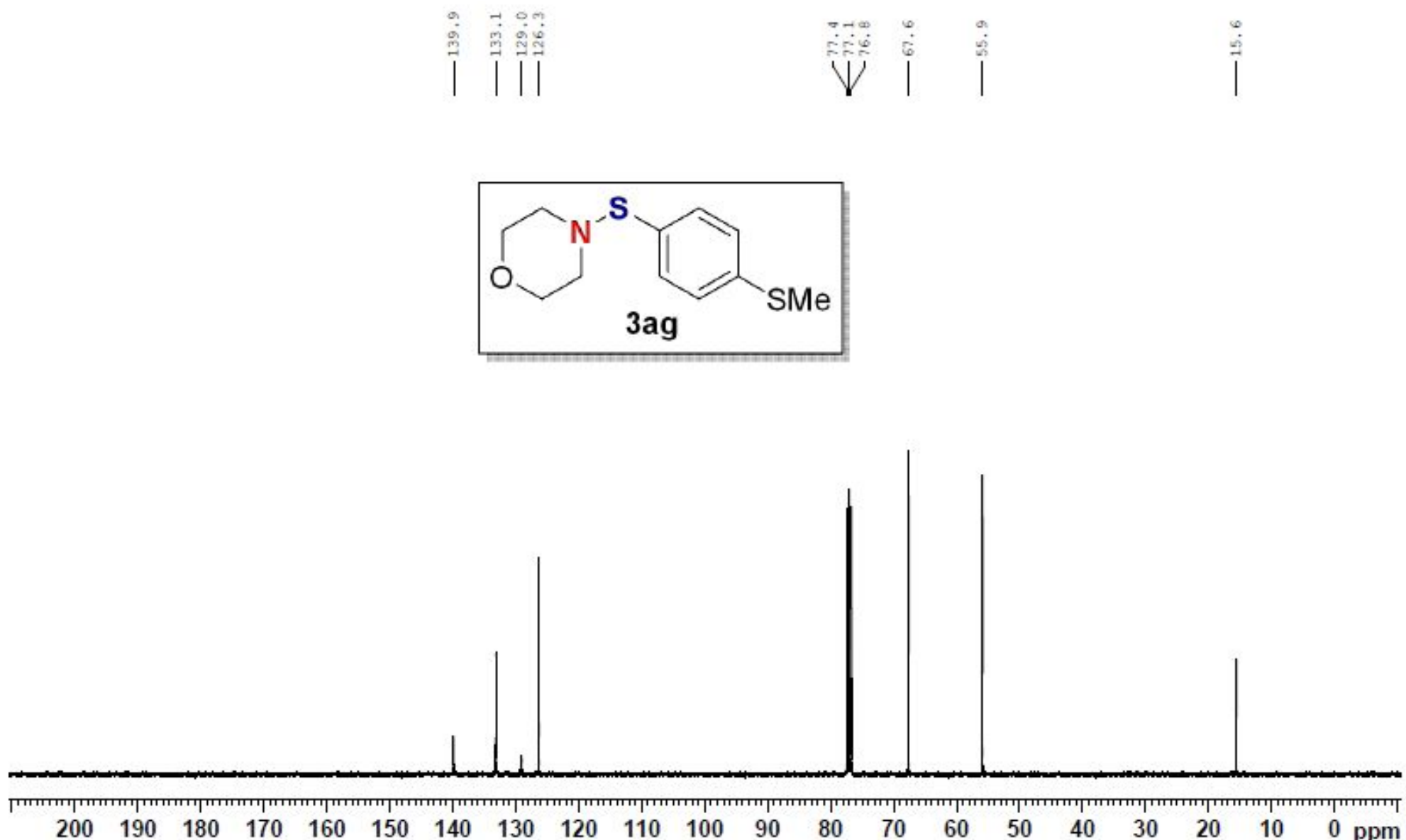

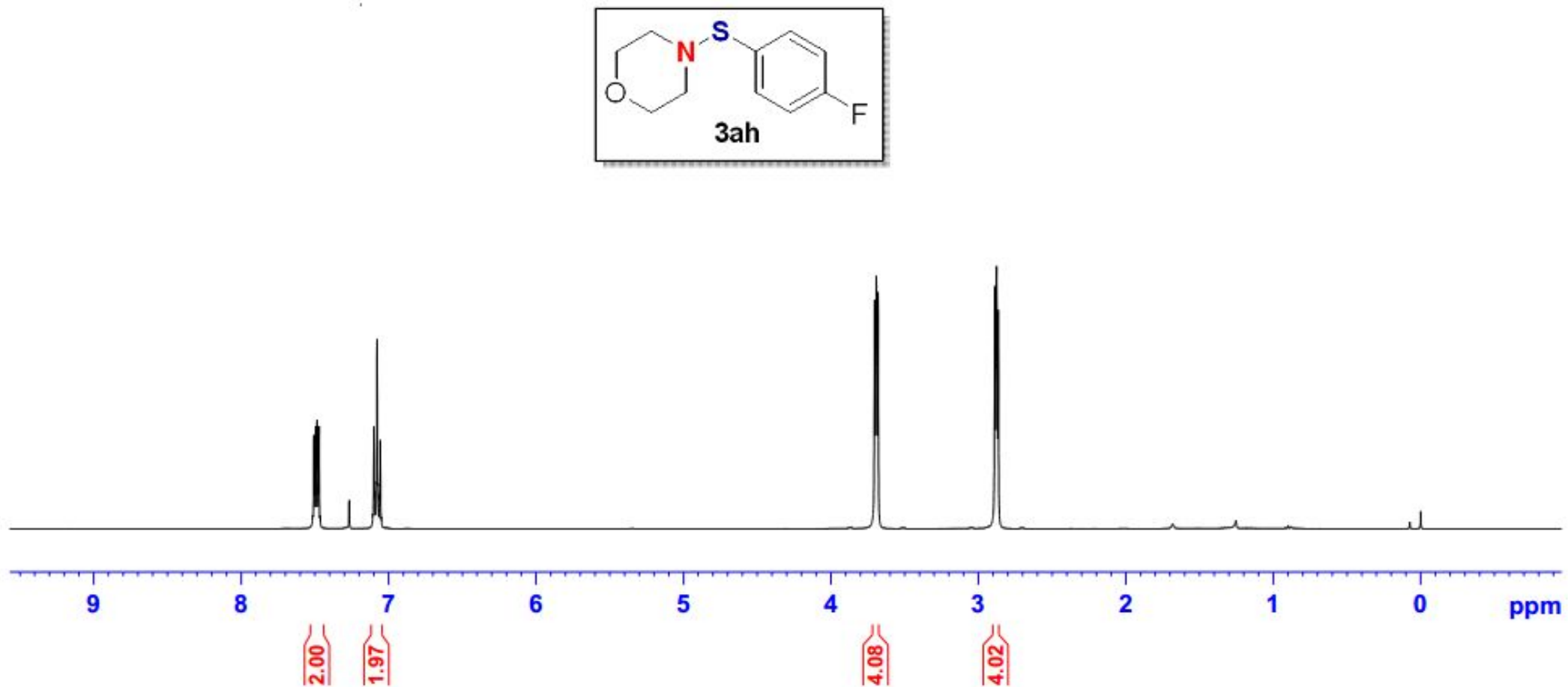


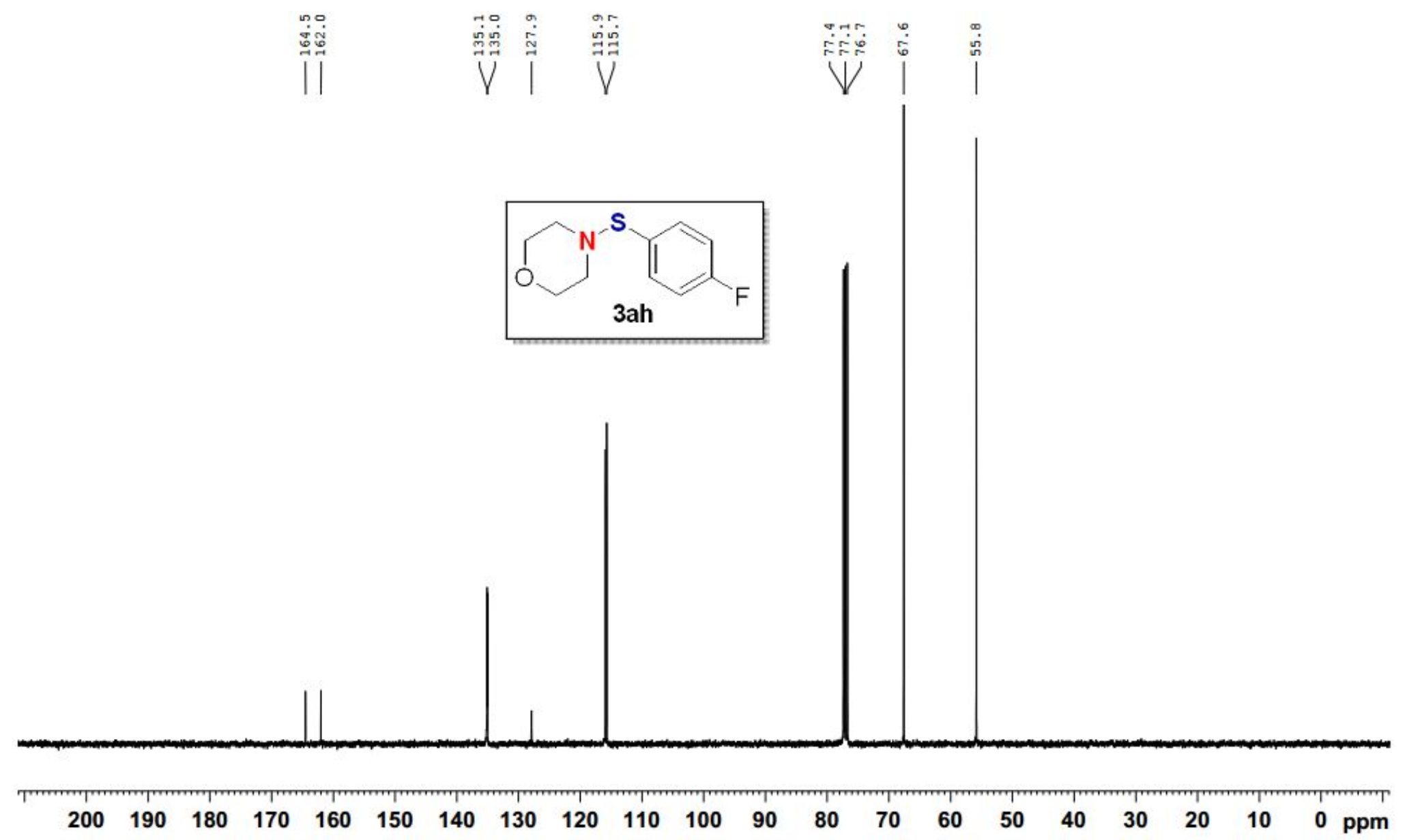


LSP-X181226-1FNMR
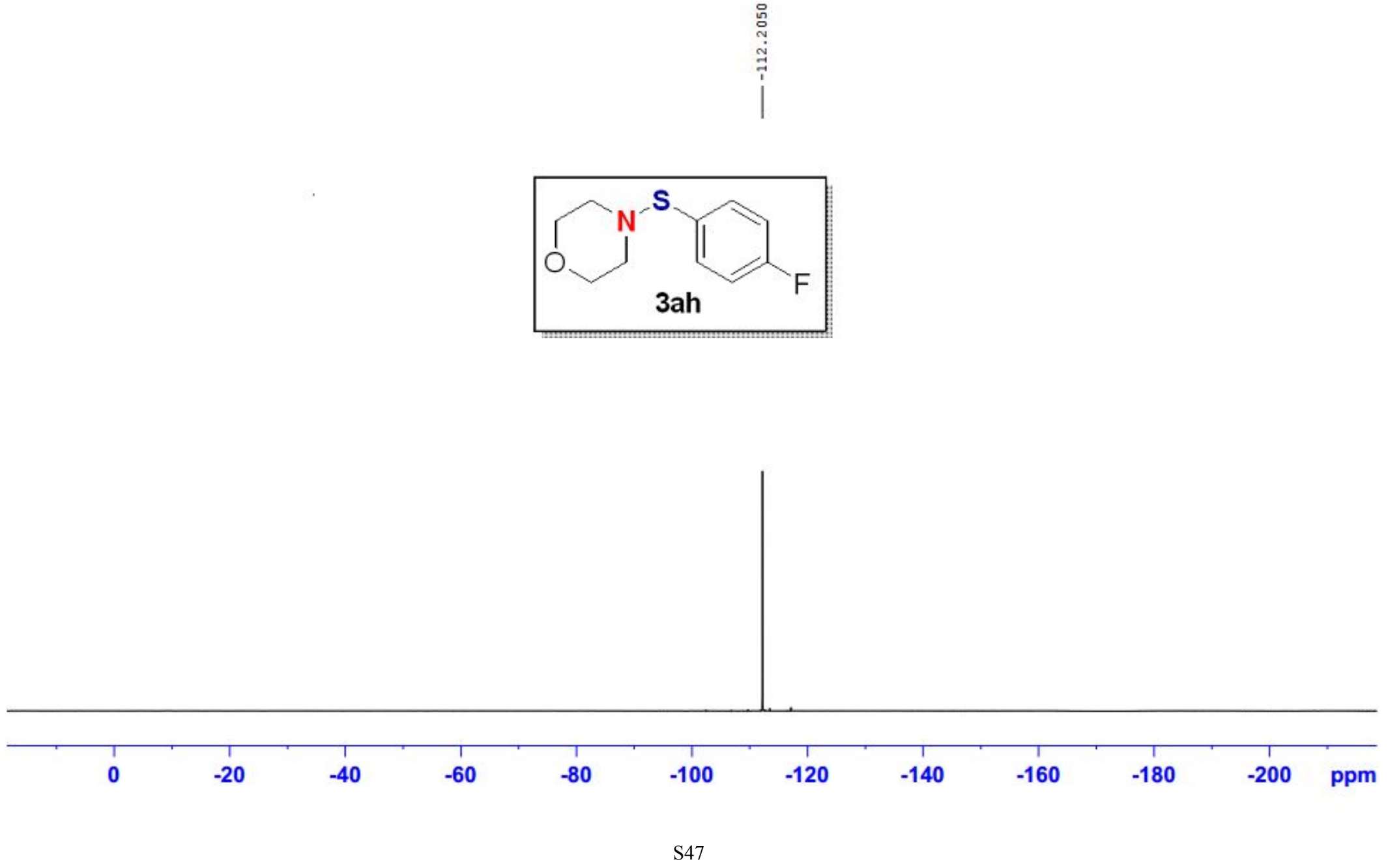

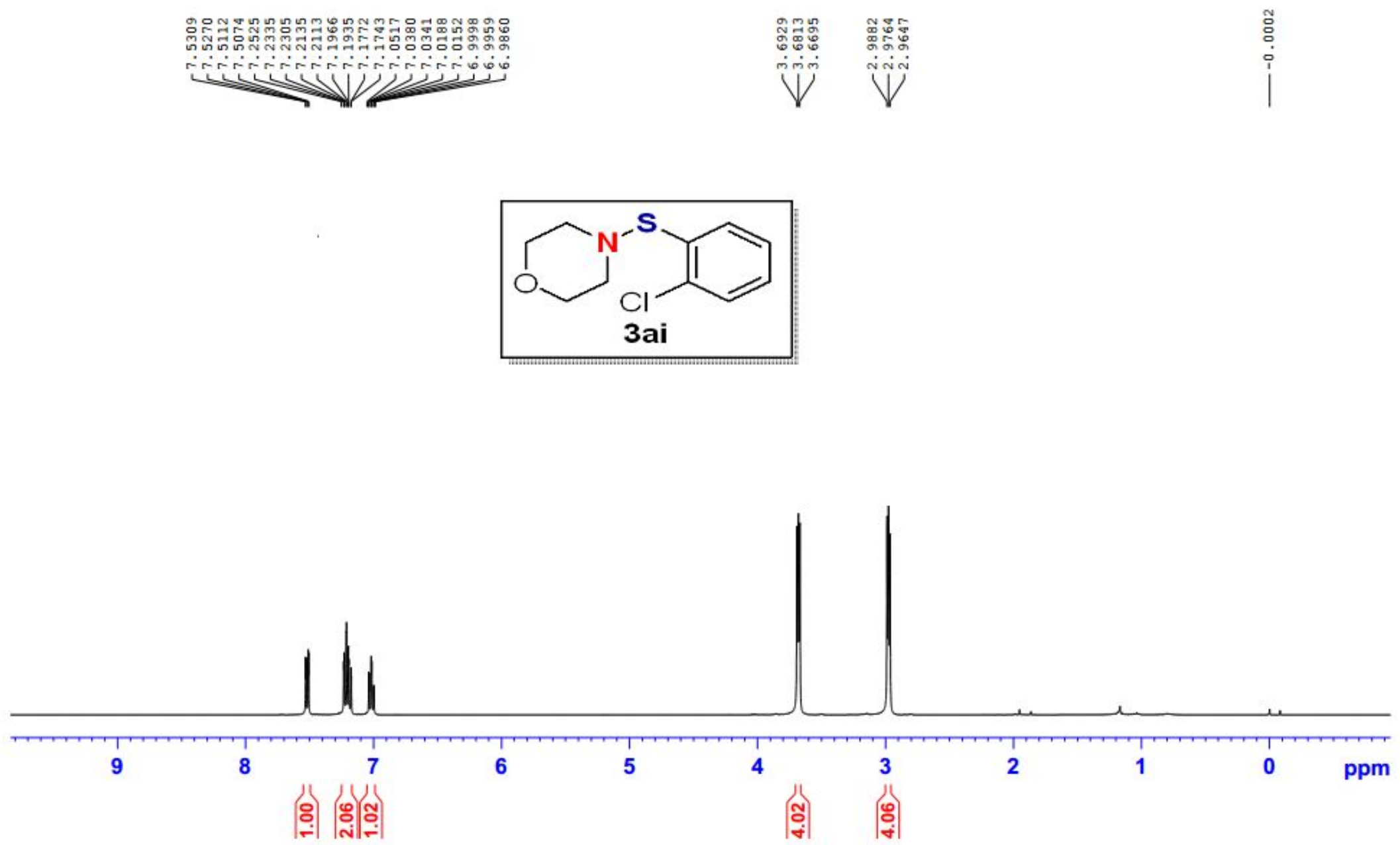


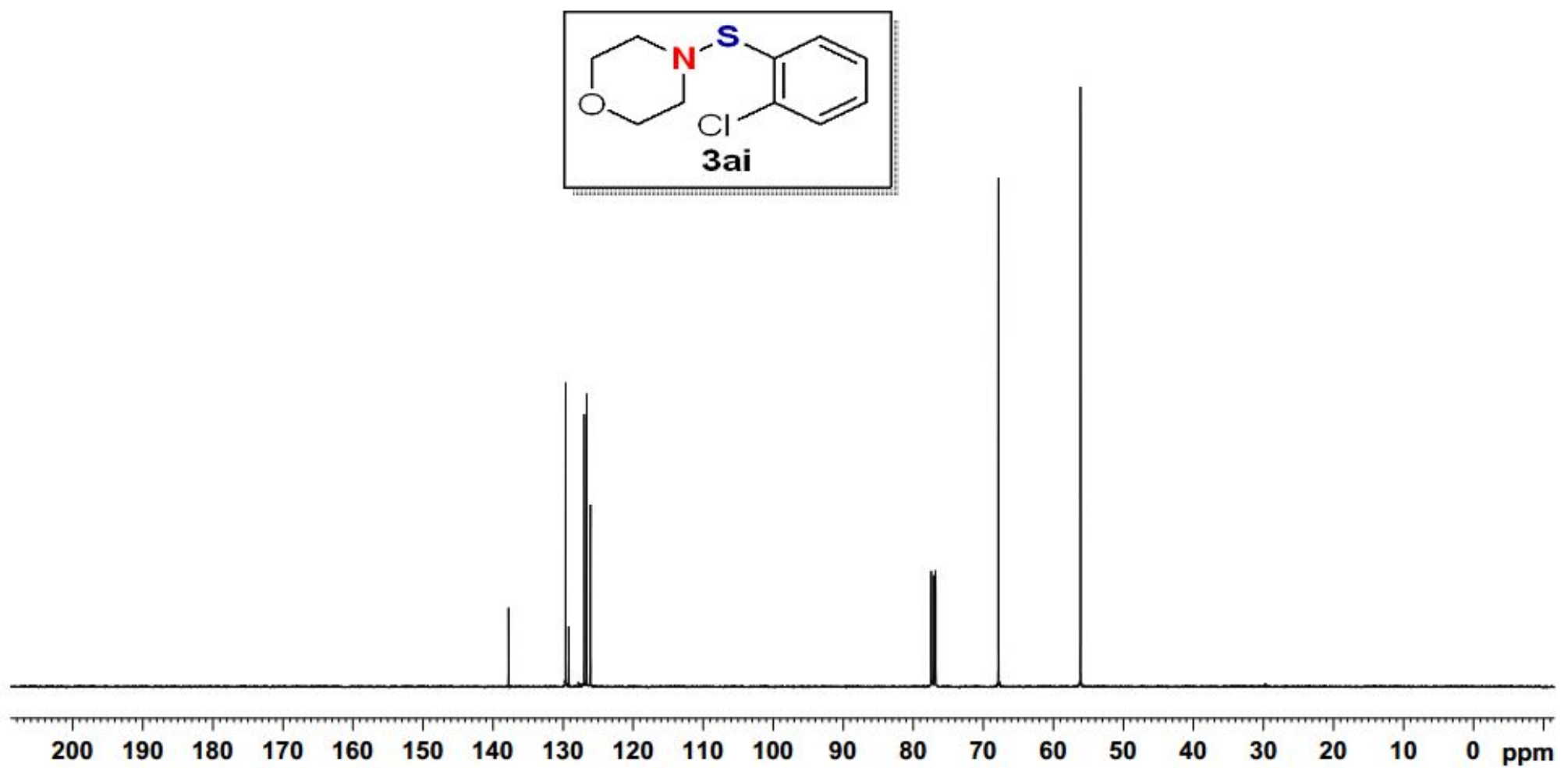


LSP-X190103-2HNMR
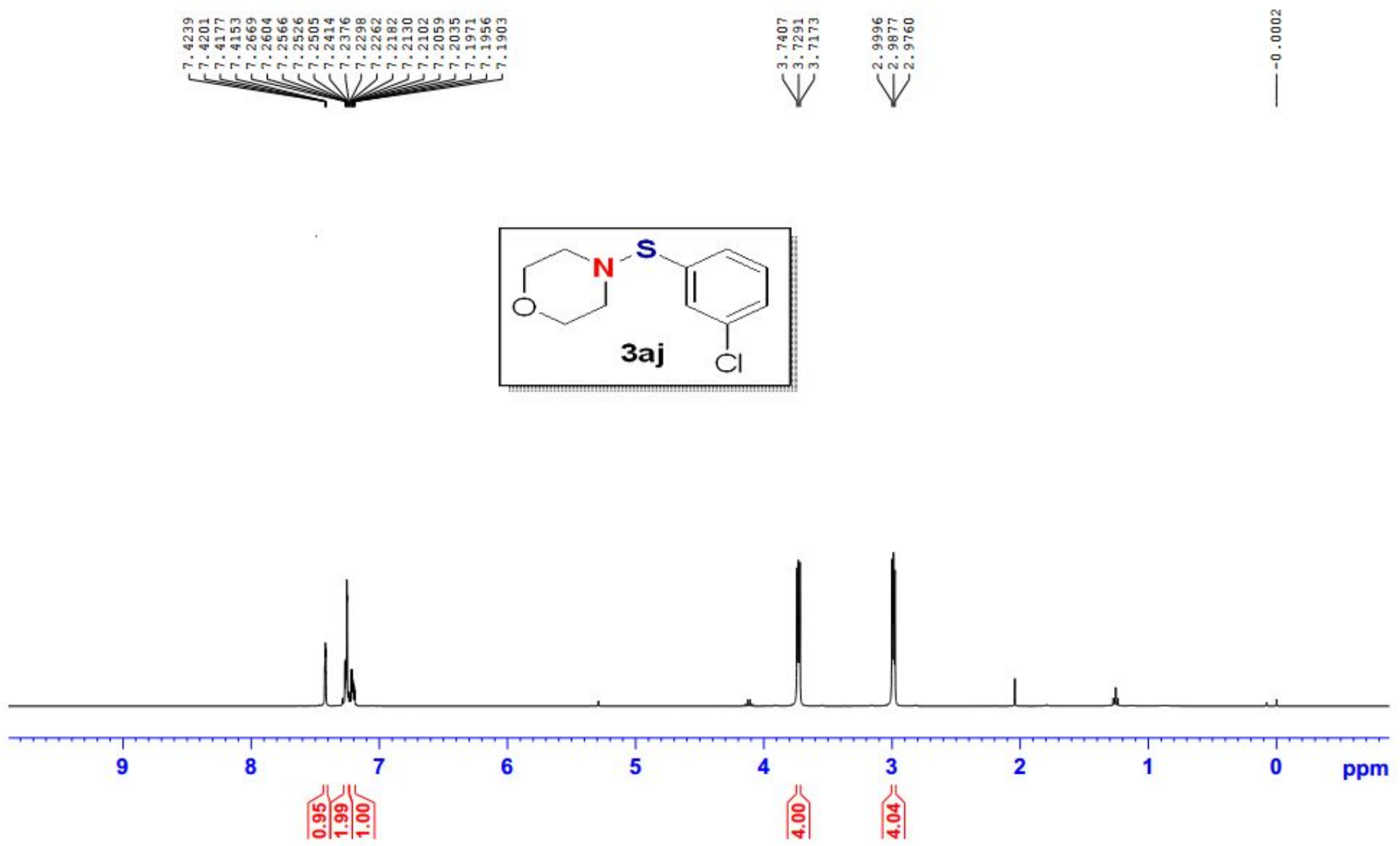
LSP-X190103-2CNMR

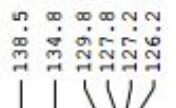

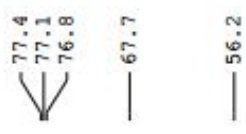

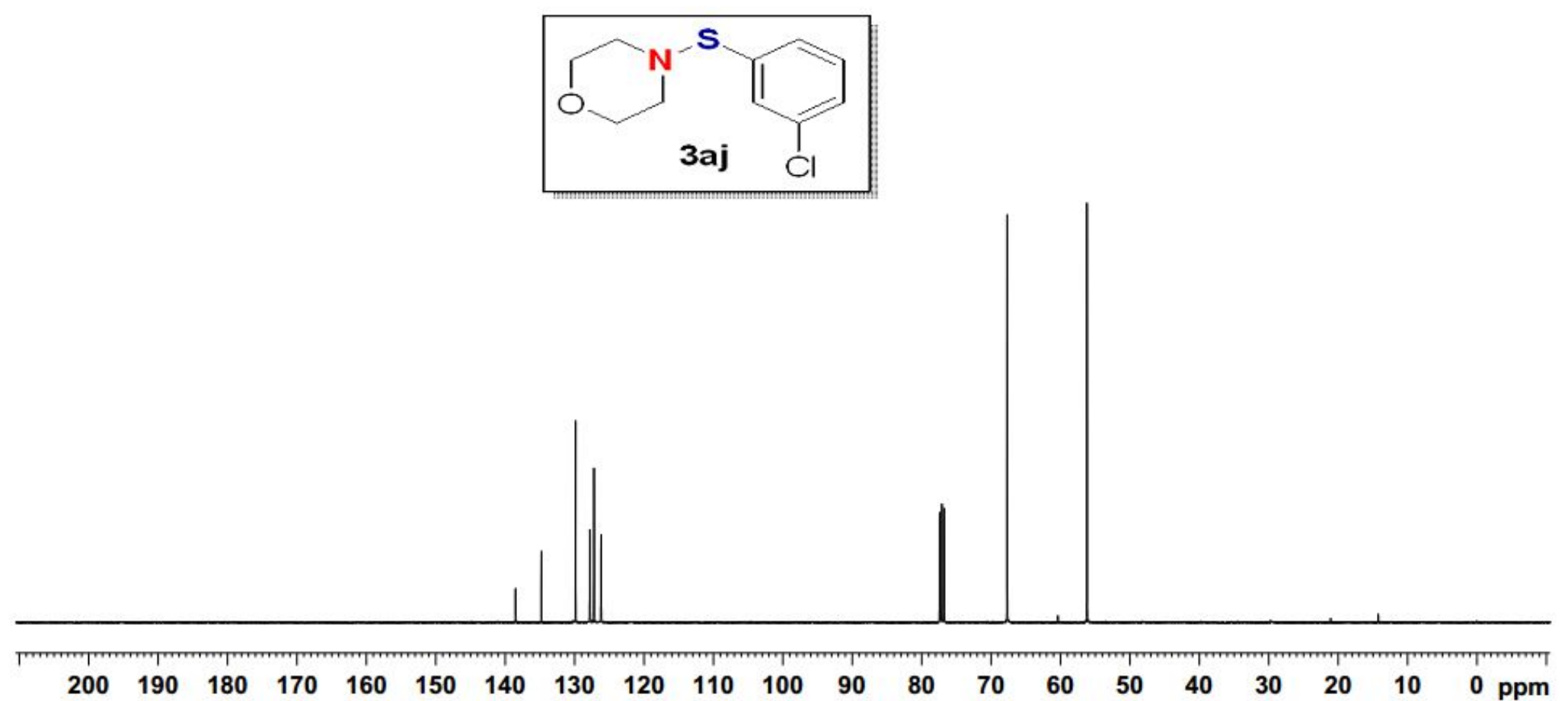



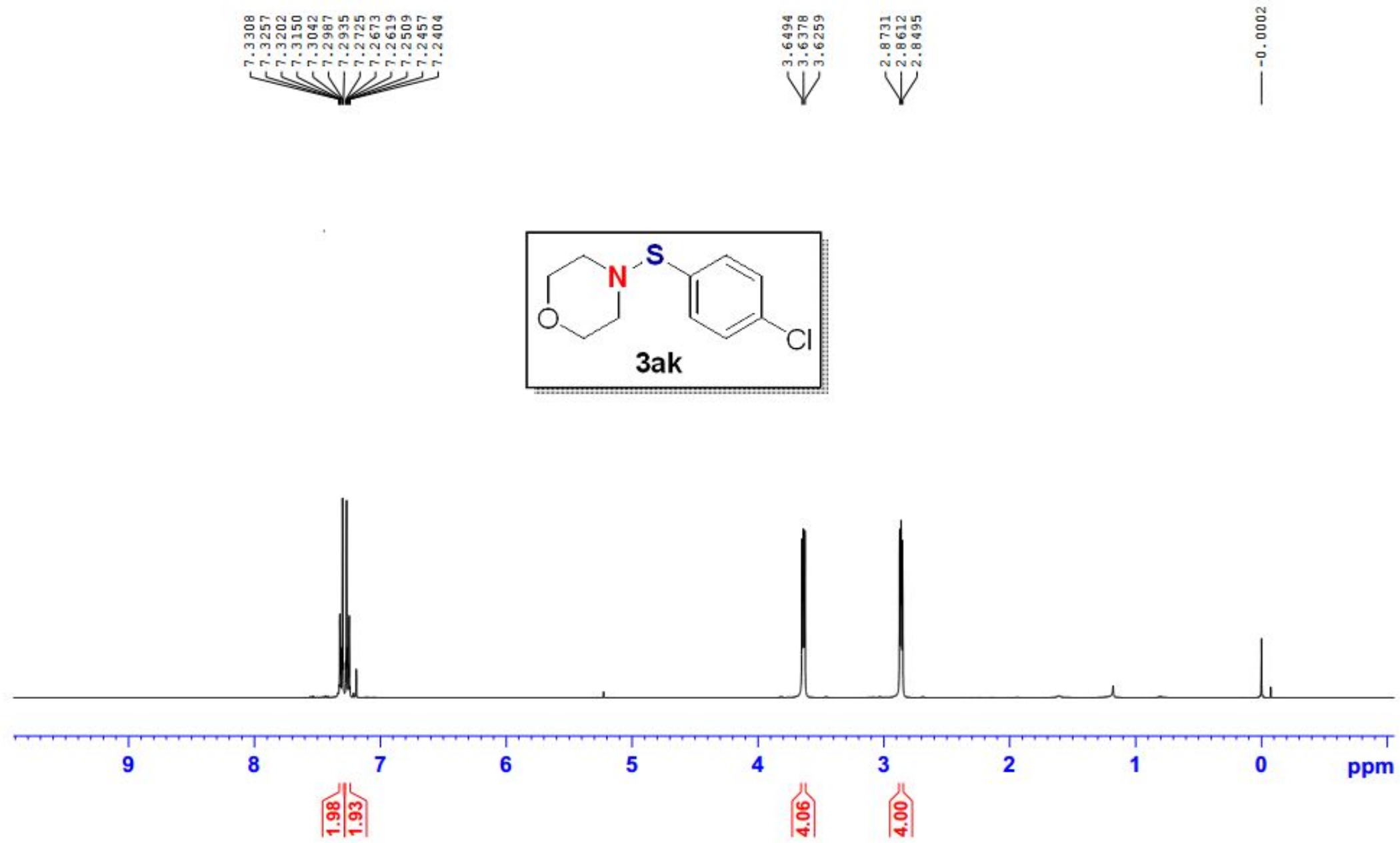
LSP-X181217-1CNMR
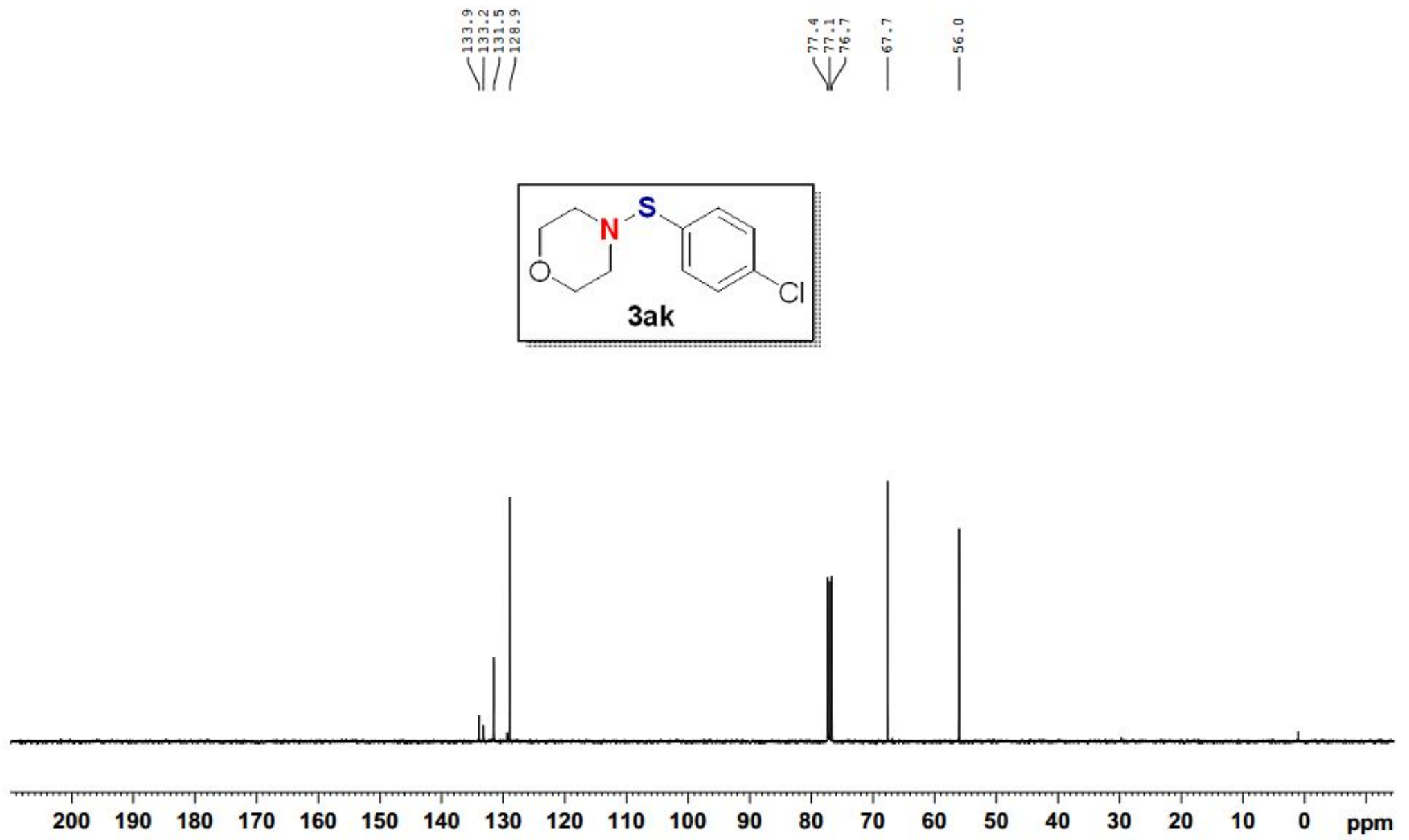
LSP-X190103-6HNMR

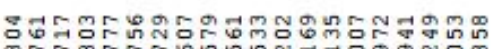

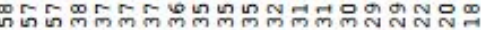

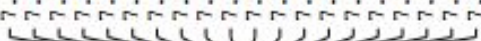

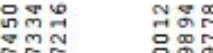
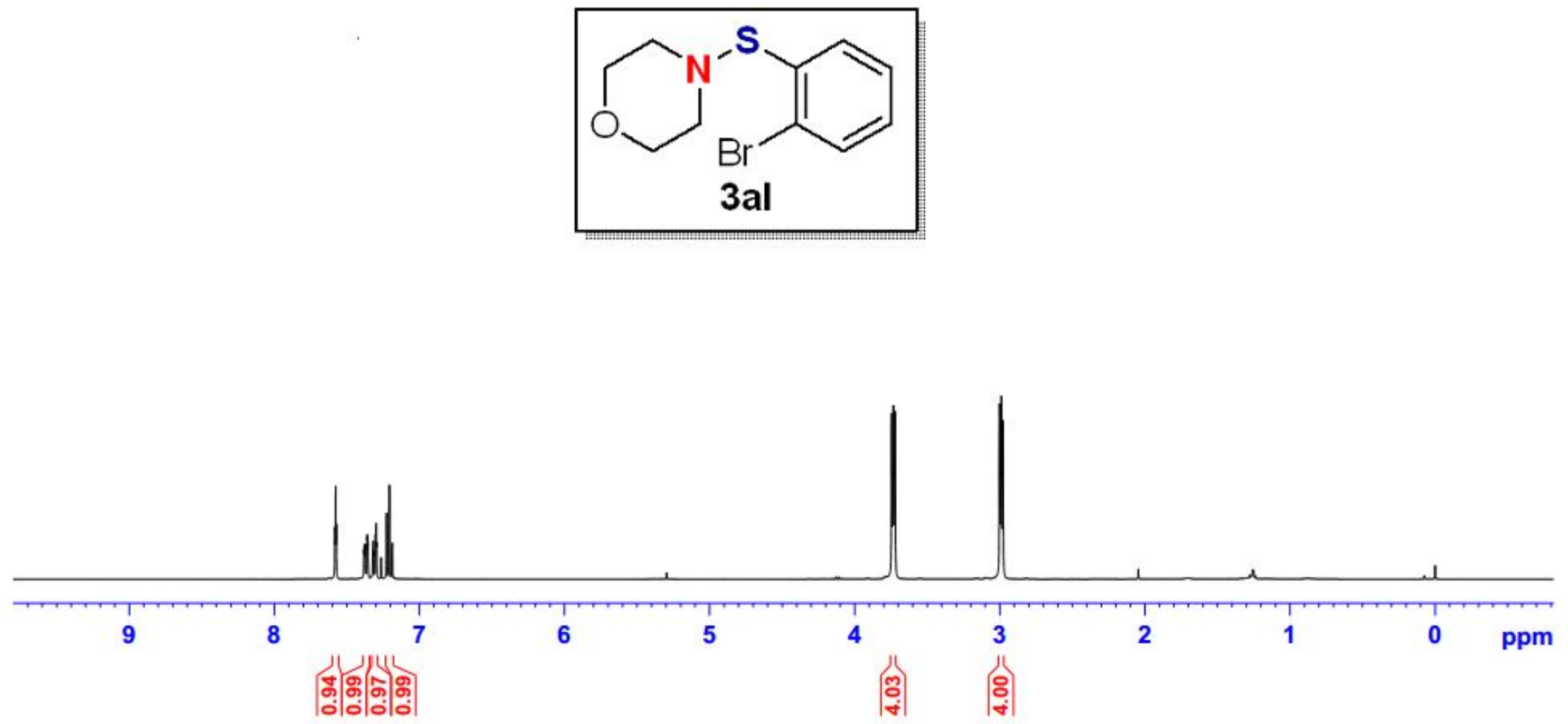

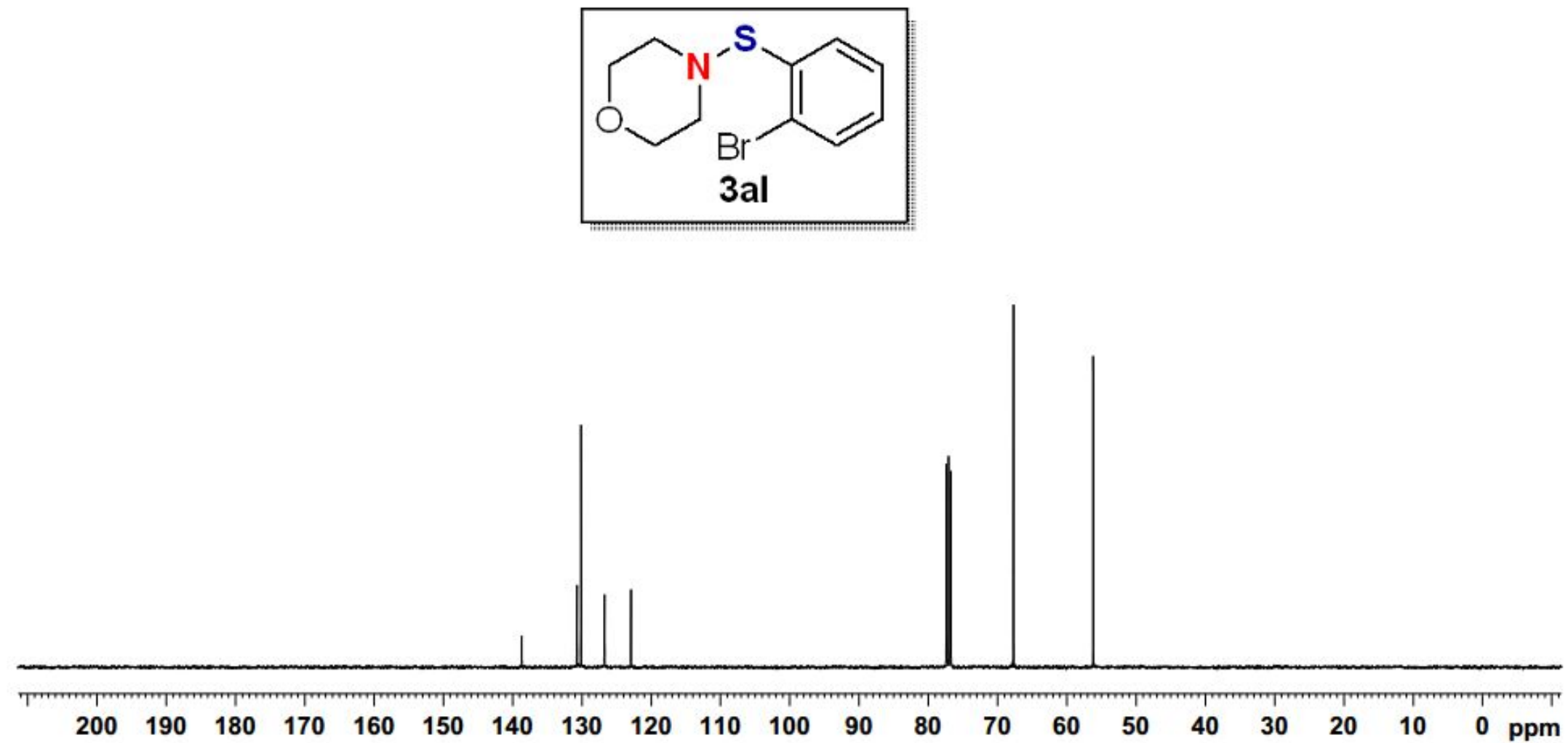
LSP-X190103-5HNMR
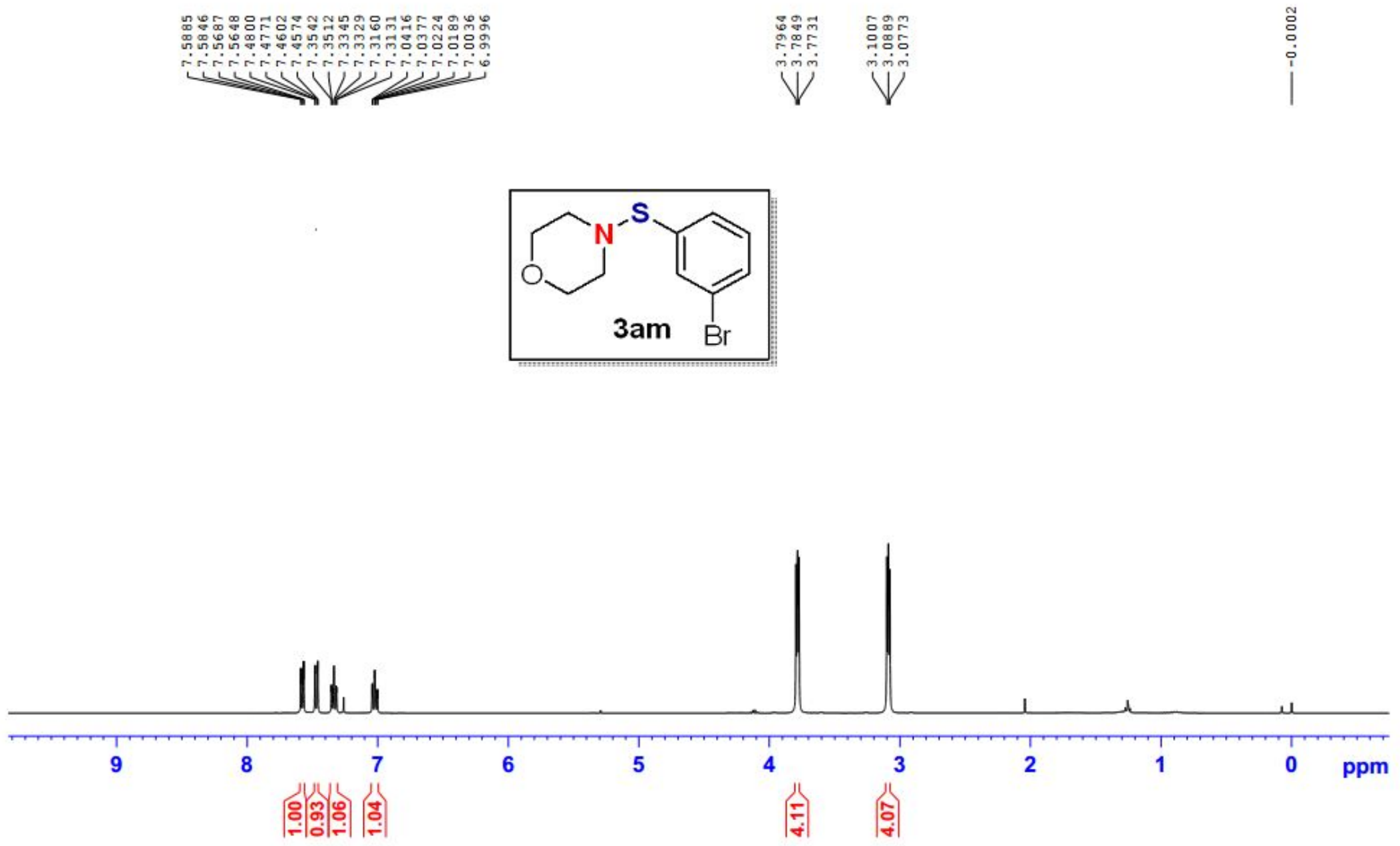
LSP-X190103-5CNMR
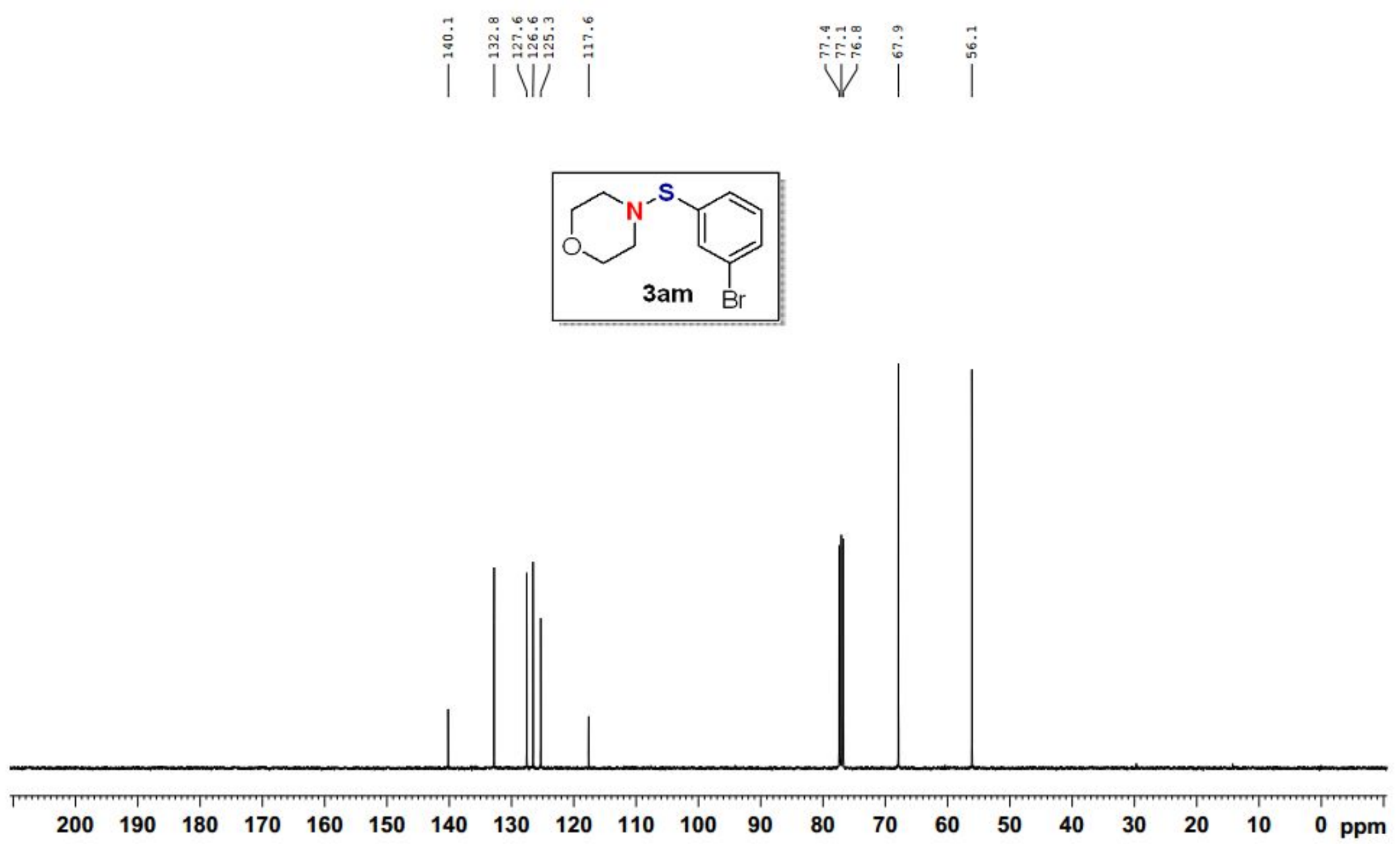

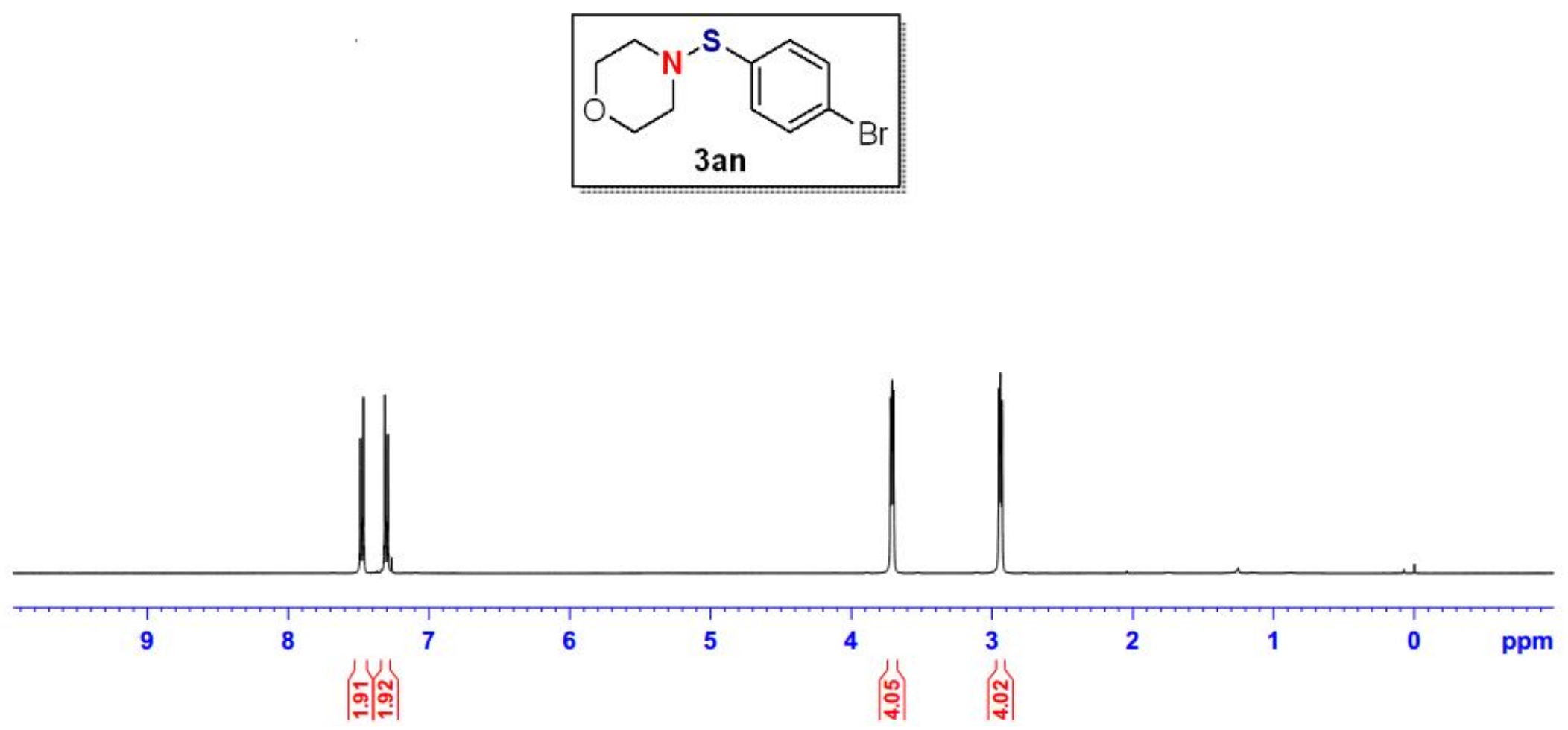

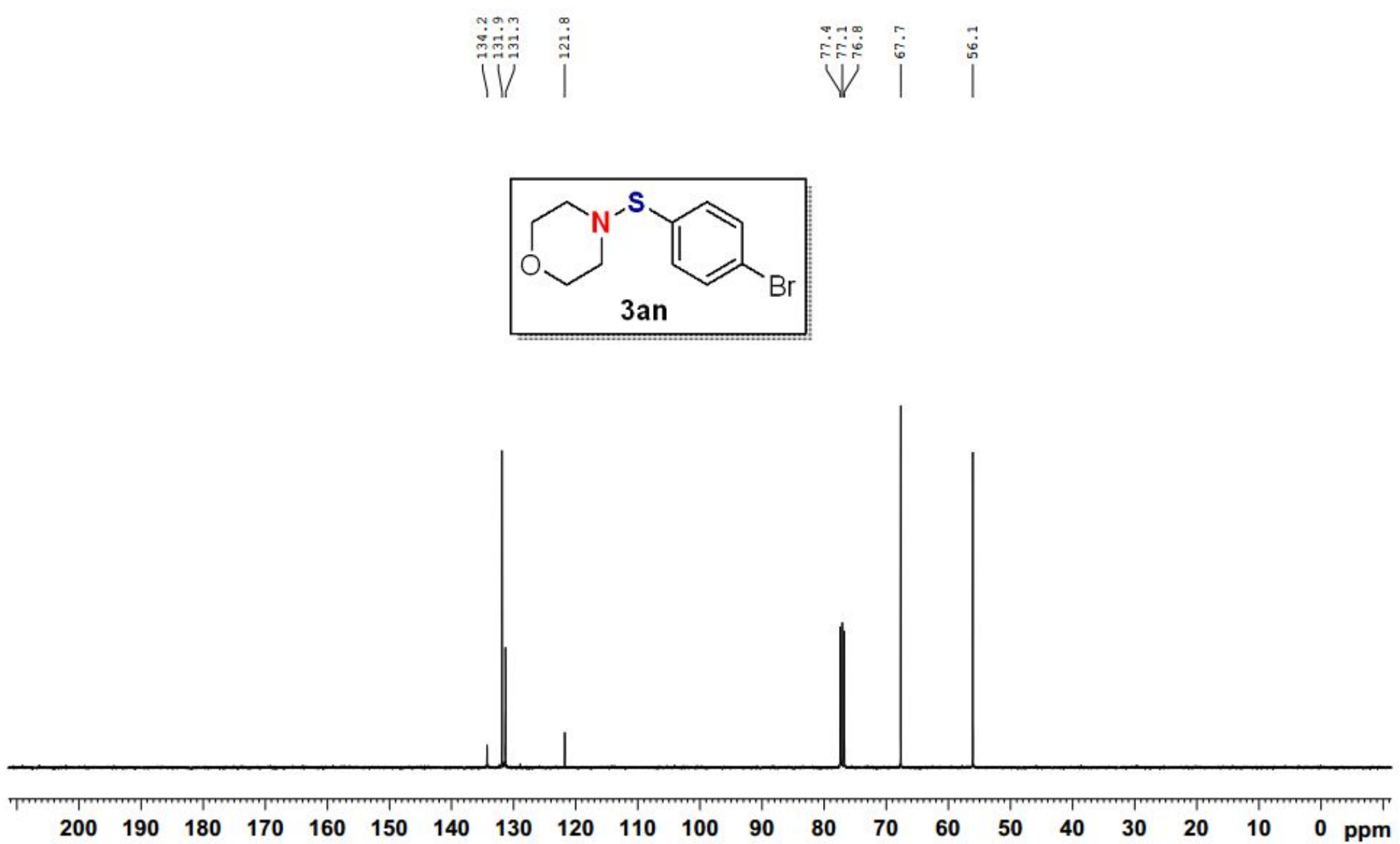
LSP-X190107-7HNMR

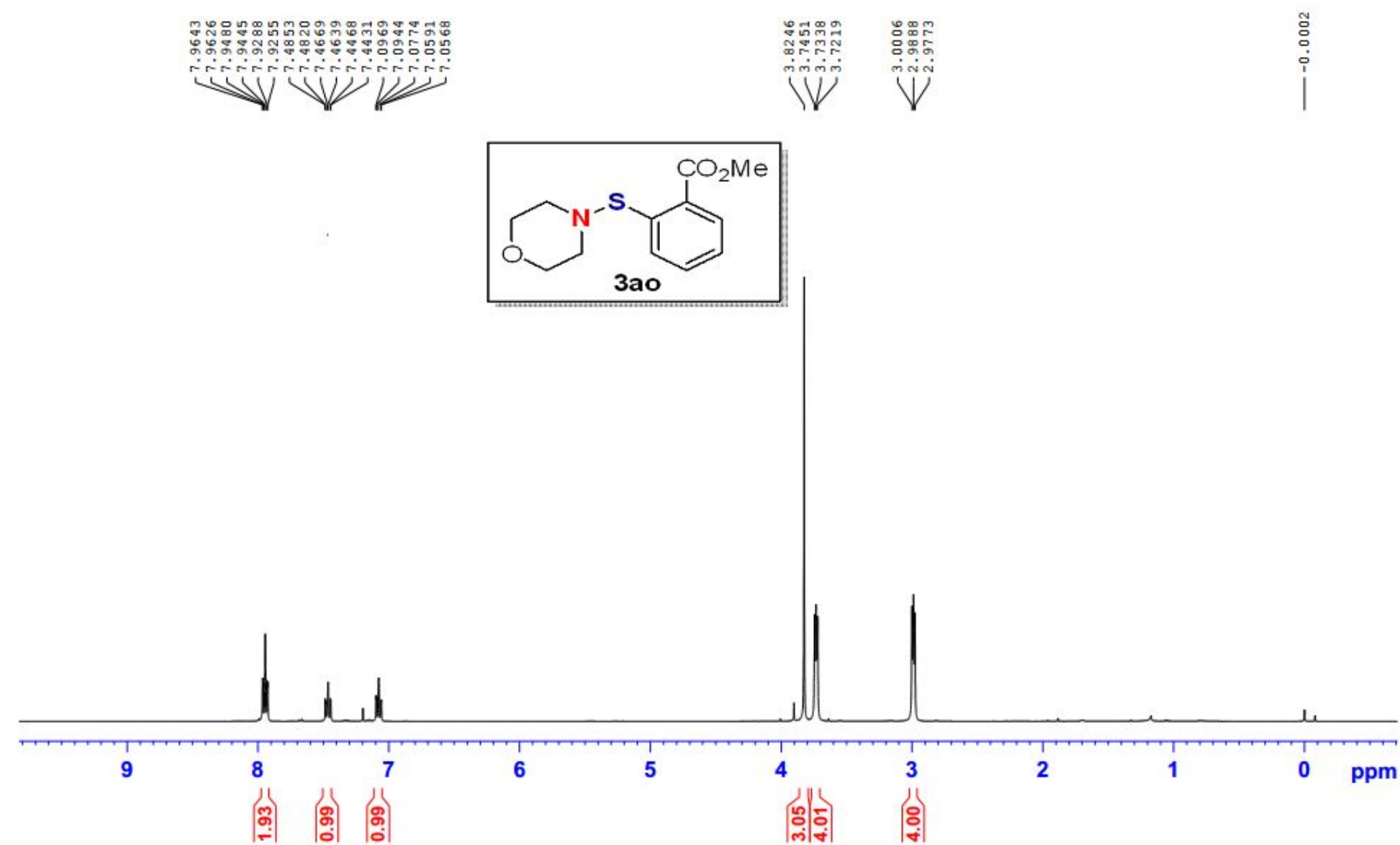


LSP-X190107-7CNMR
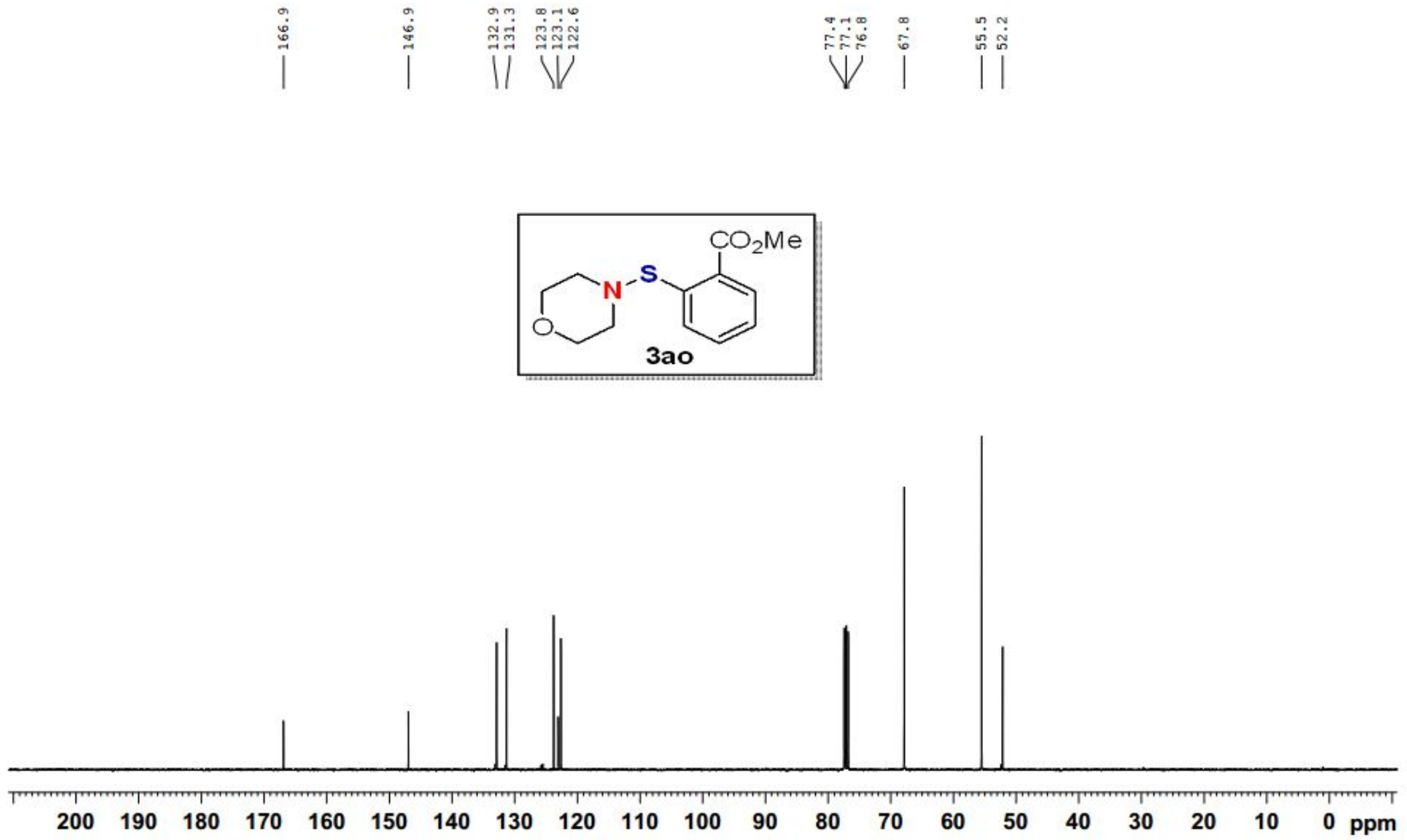
LSP-X190103-4 HNMR
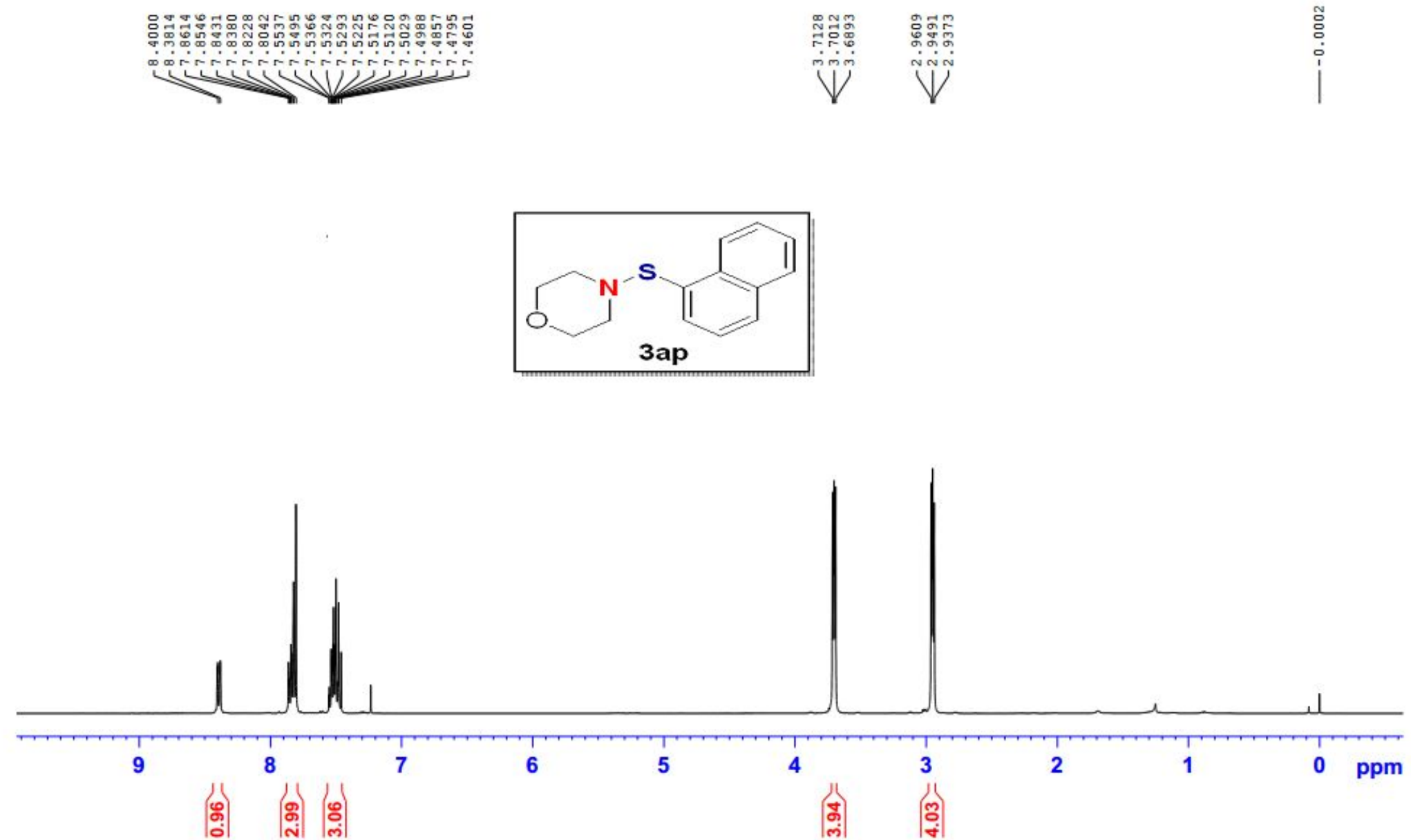

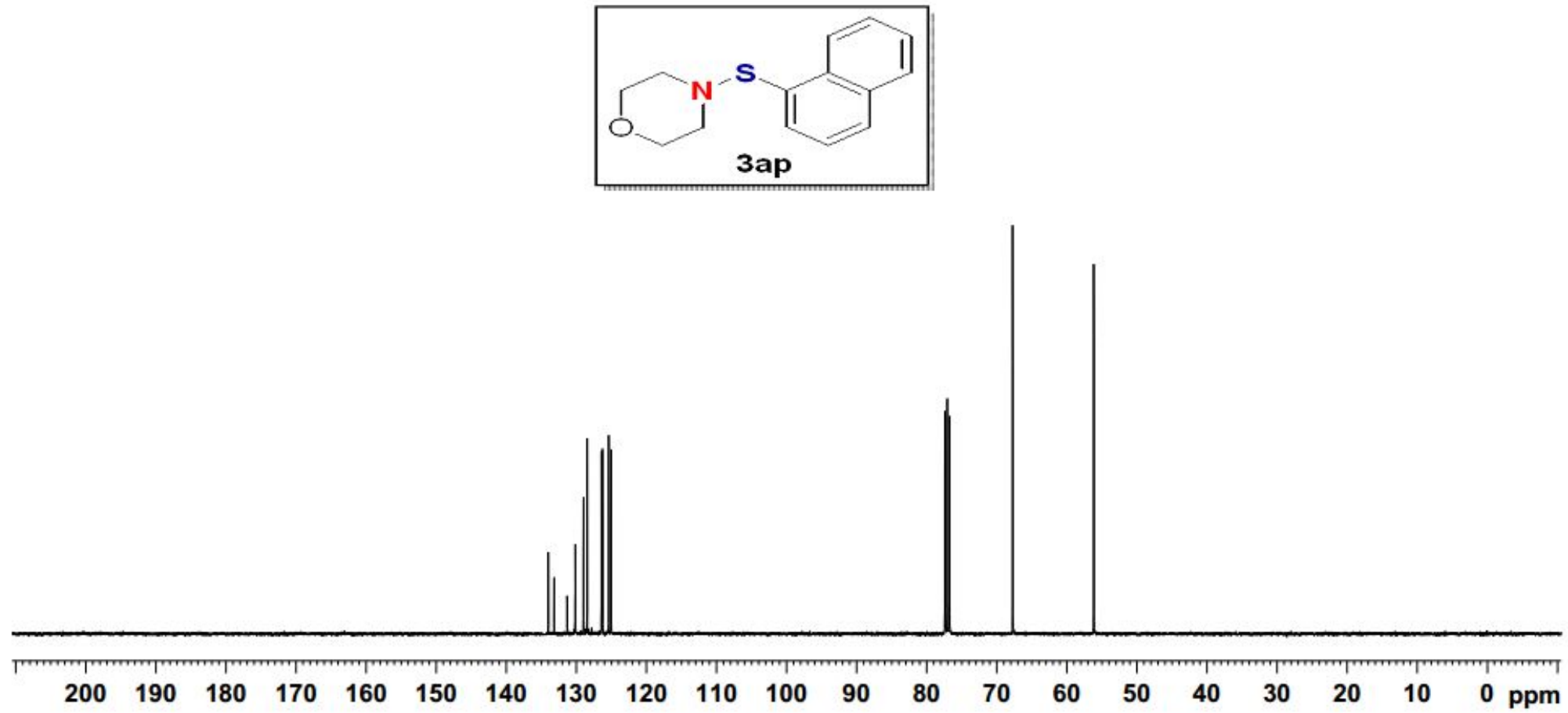

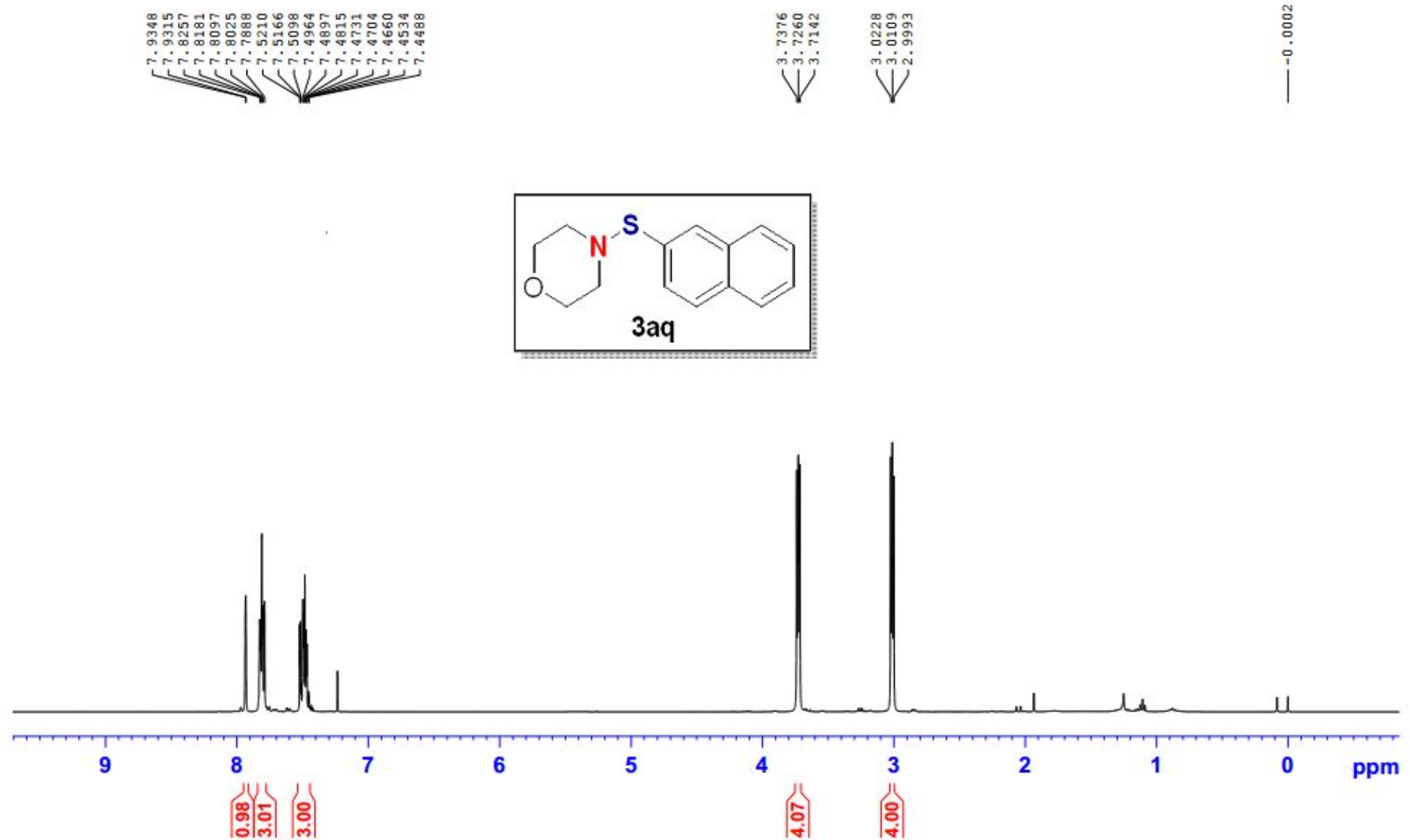
LSP-X190103-3CNMR

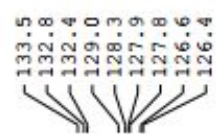

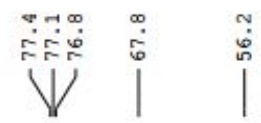
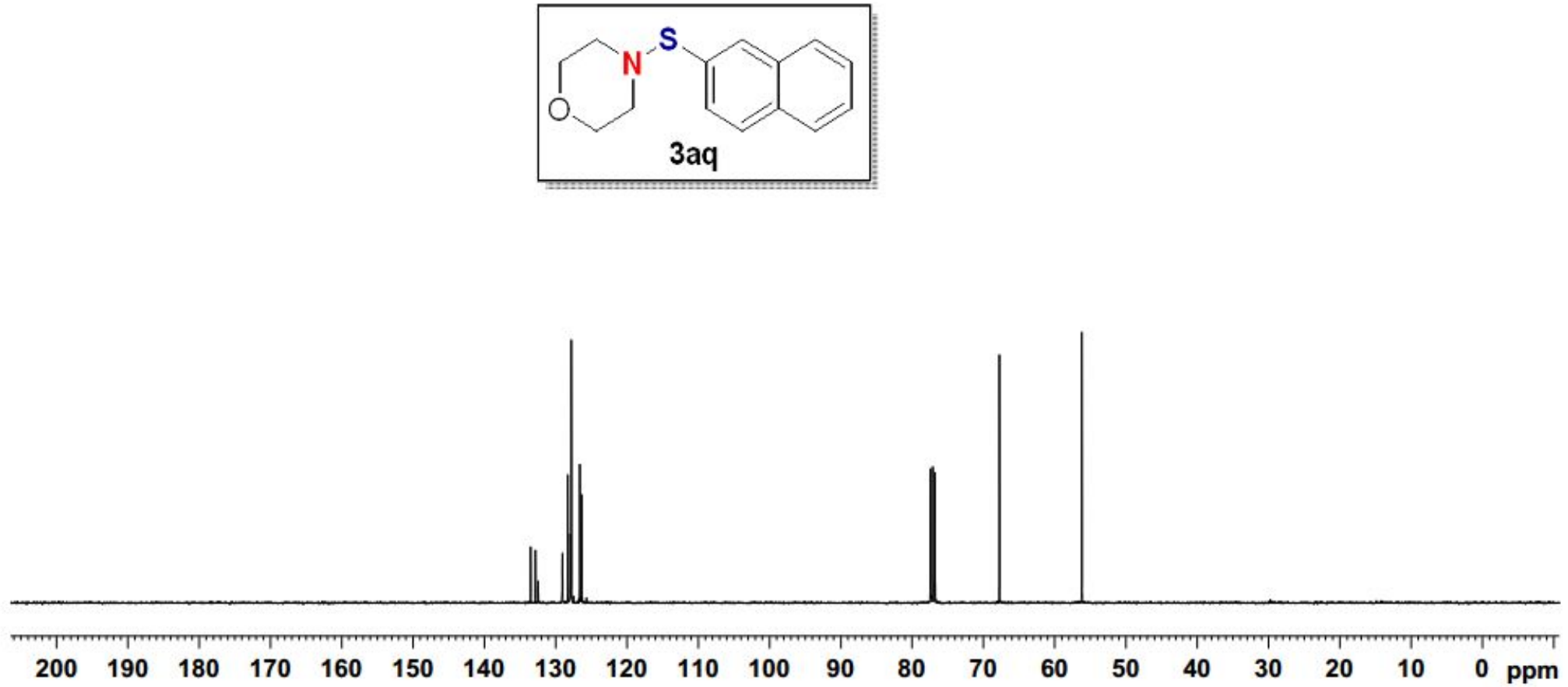
LSP-X190107-1HNMR
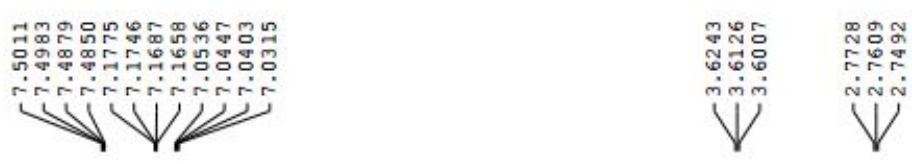

|
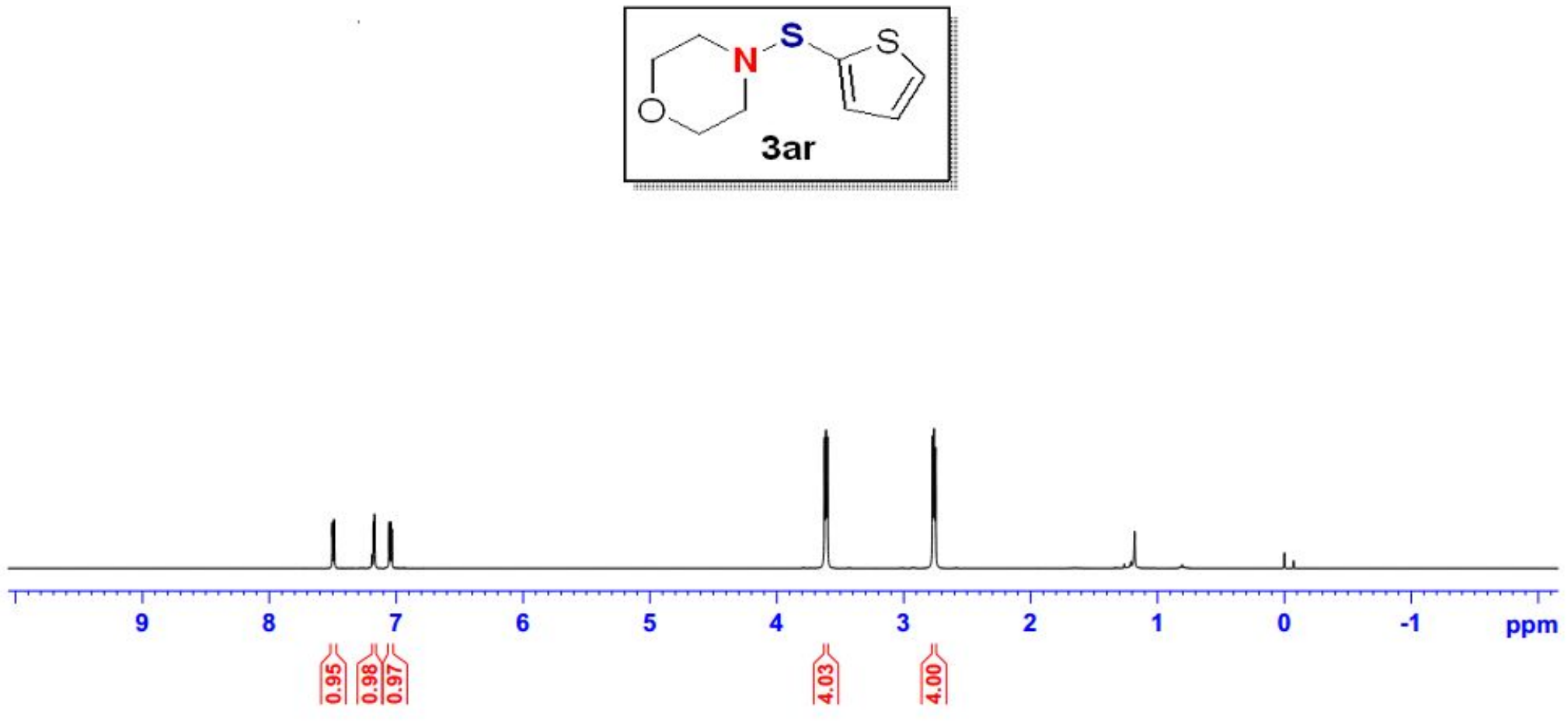
LSP-X190107-1CNMR

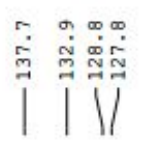

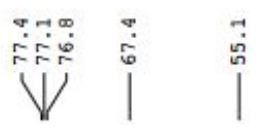
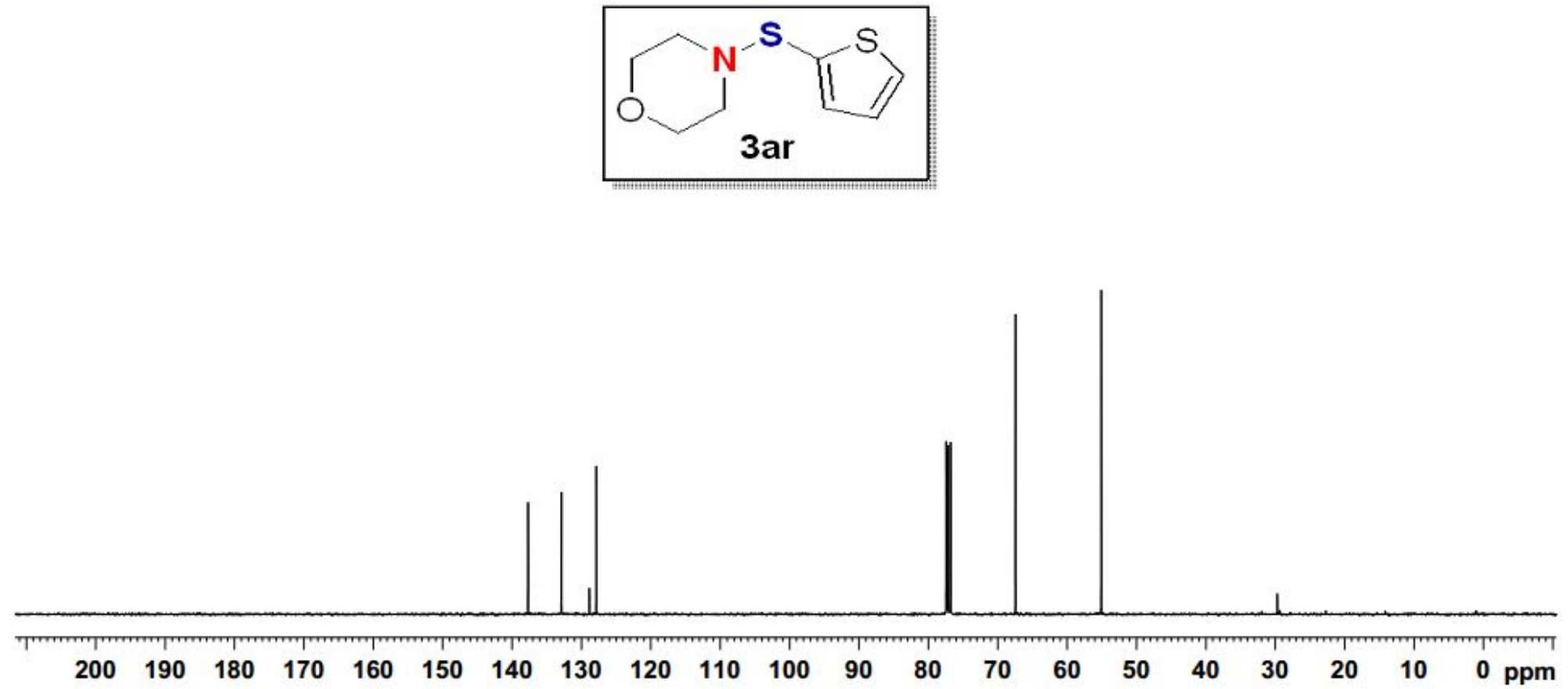
LSP-X190107-4HNMR
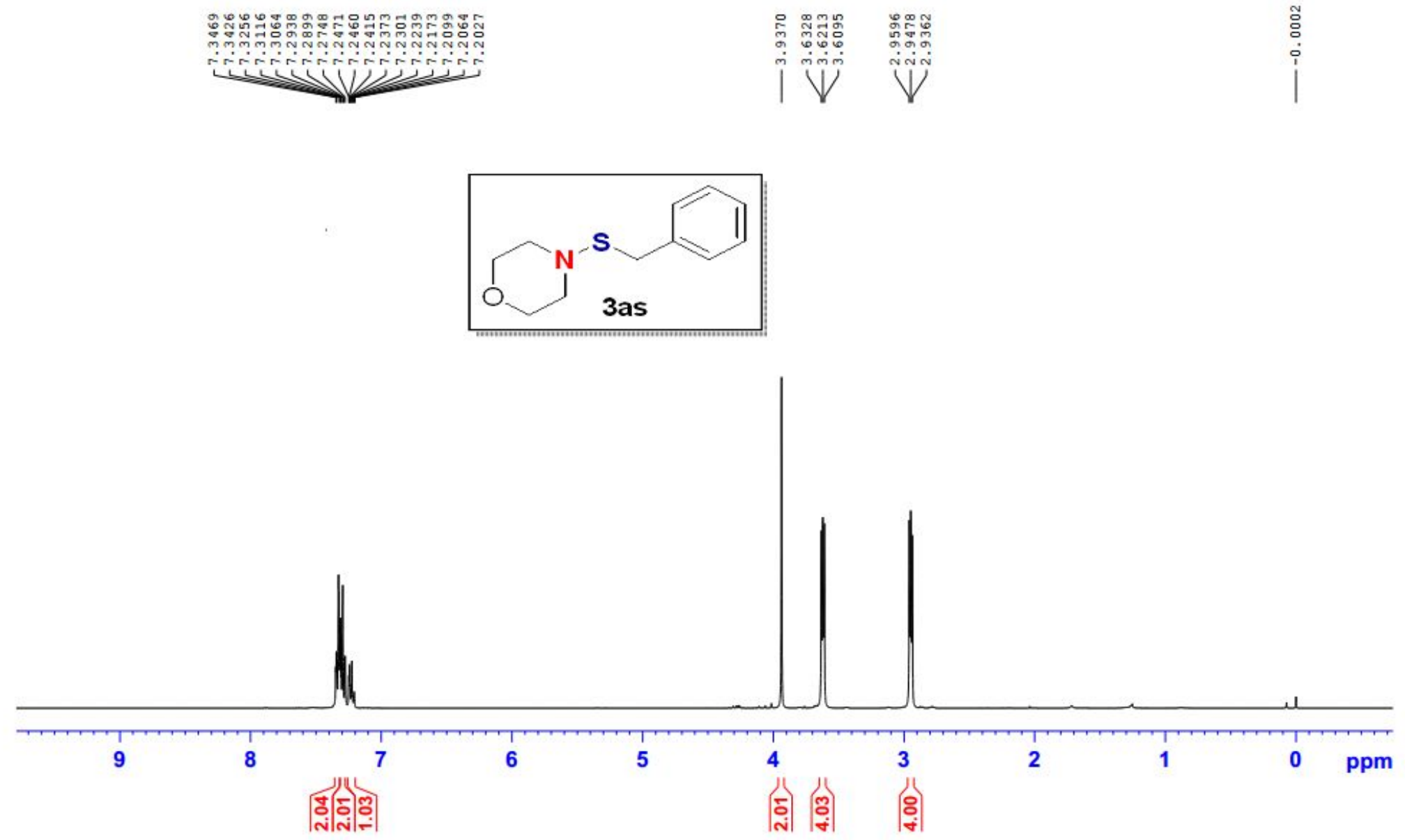
LSP-X190107-4CNMR
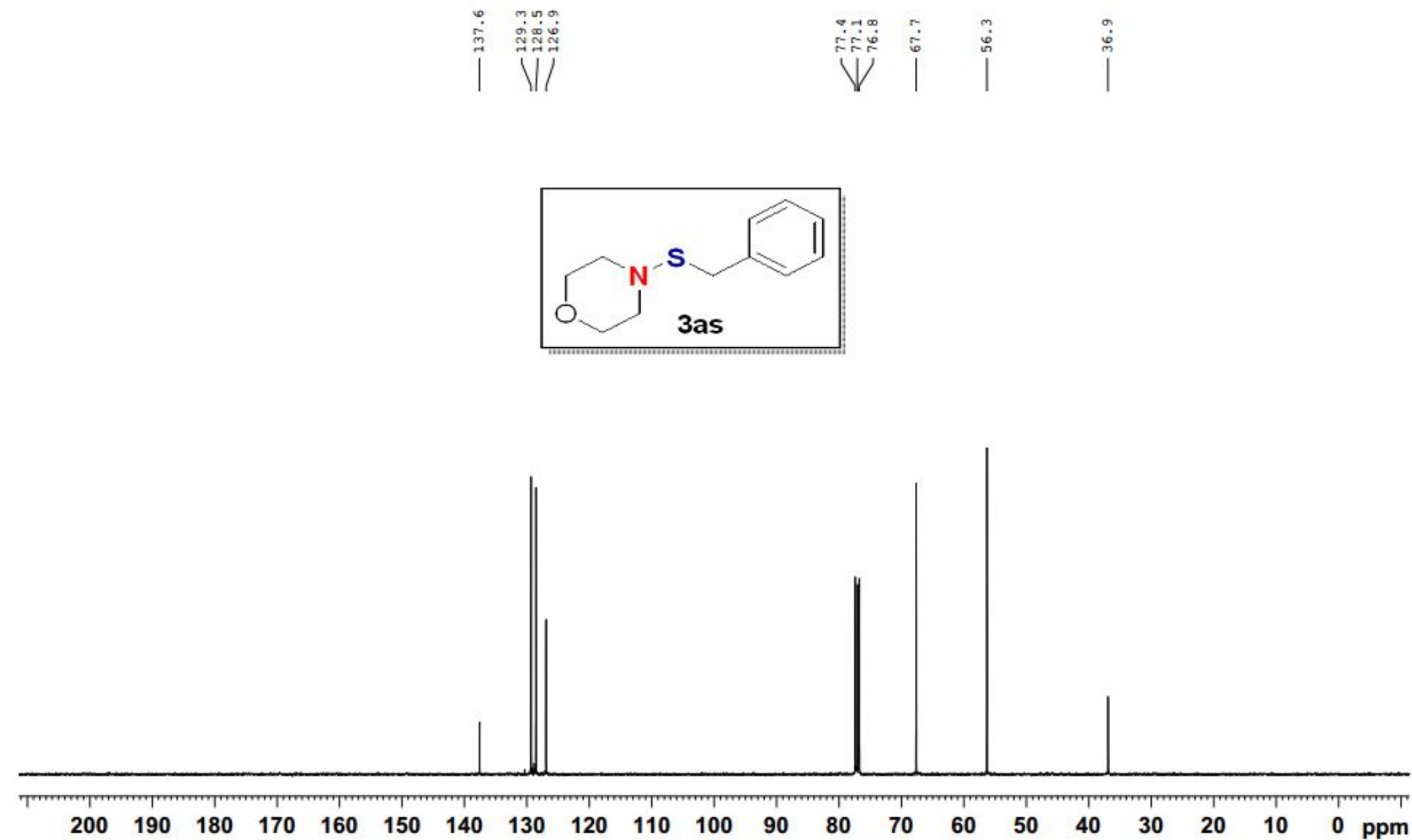

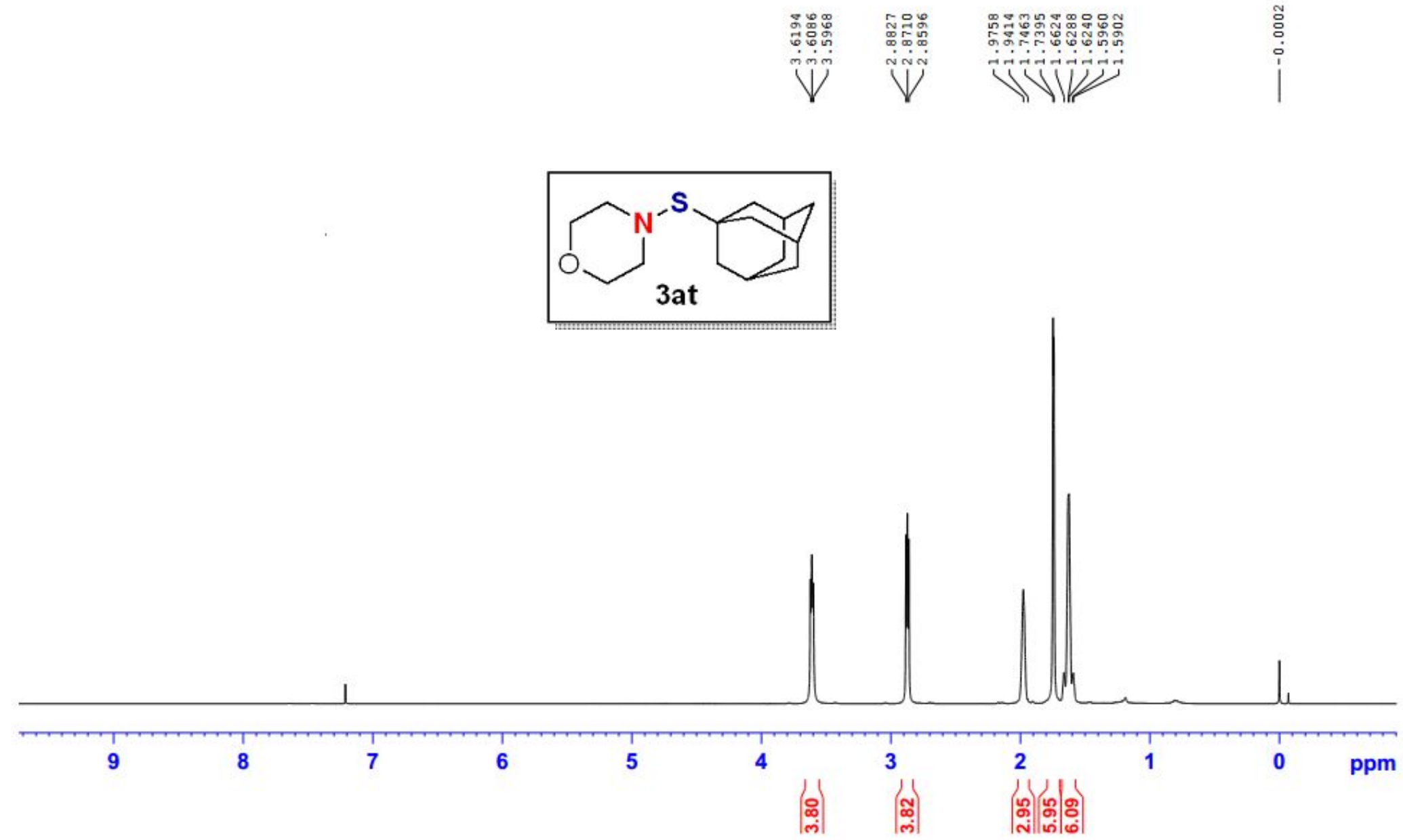
LSP-X190122-2CNMR

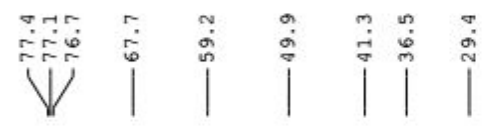
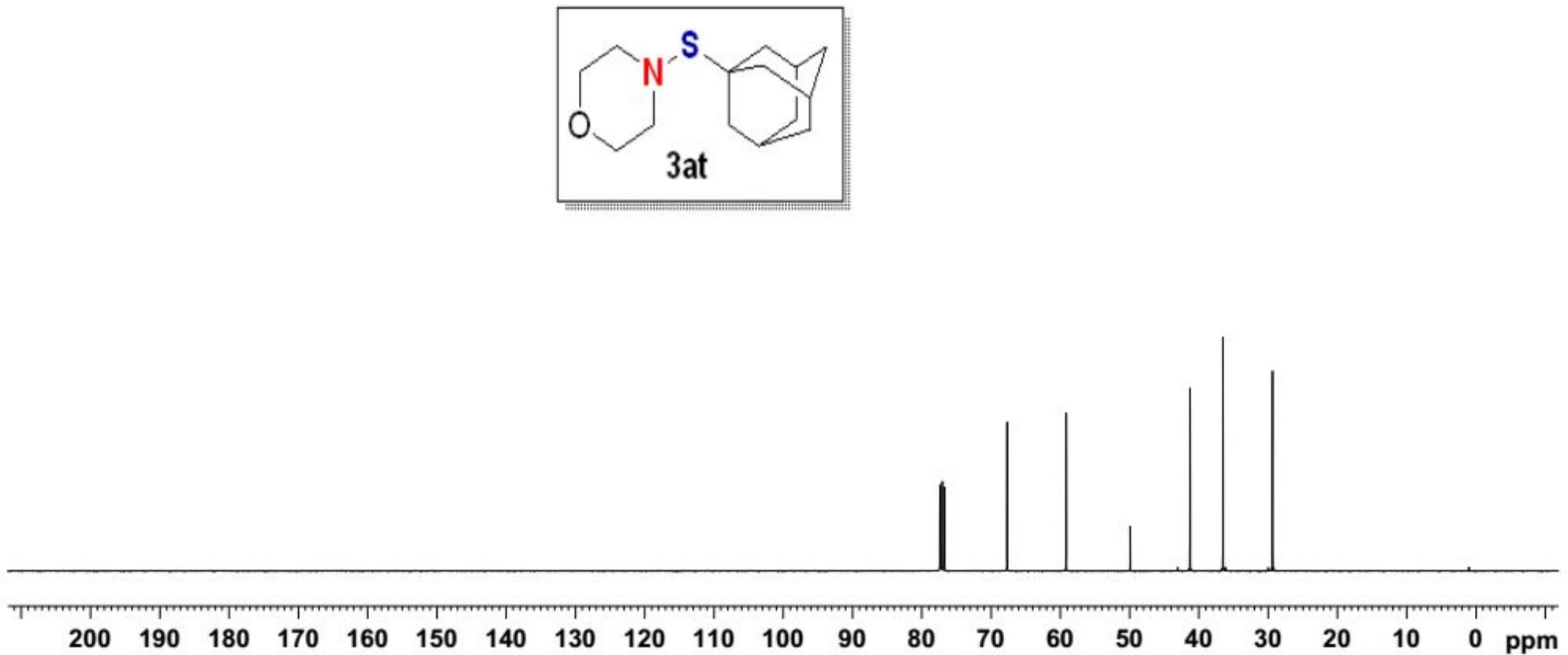
LSP-X190121-1HNMR

Vท
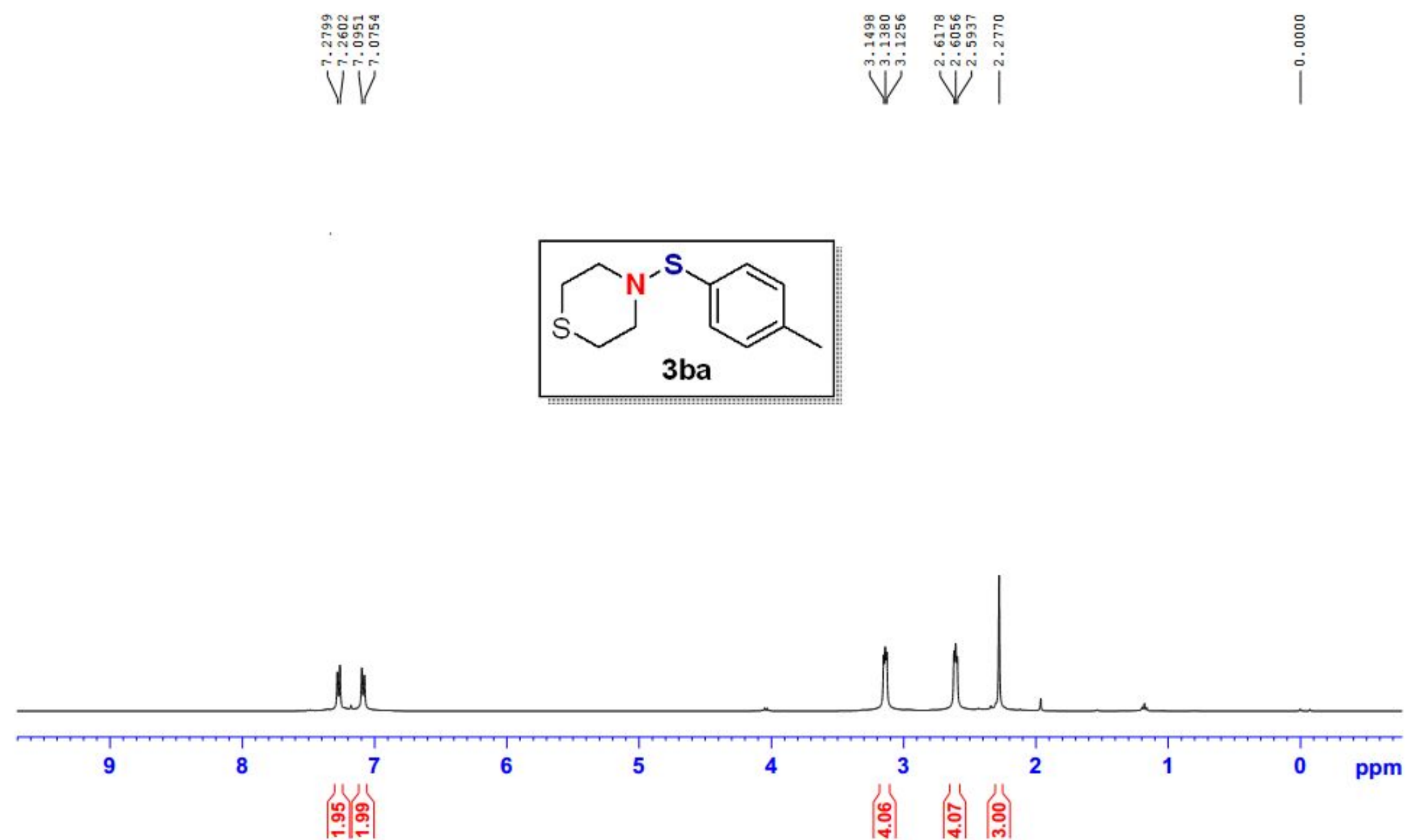
LSP-X190121-1CNMR
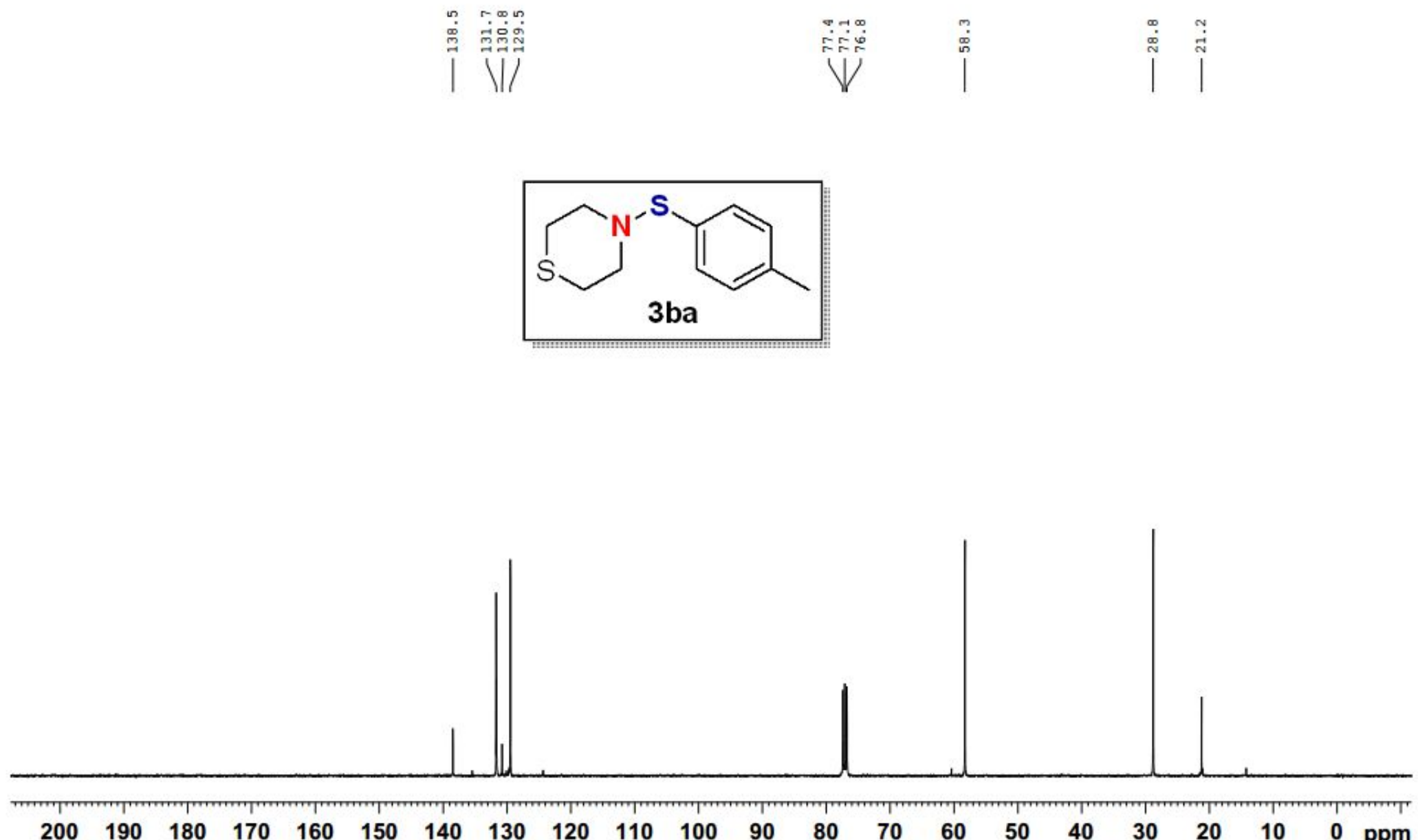
LSP-X190107-6-HNMR

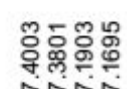

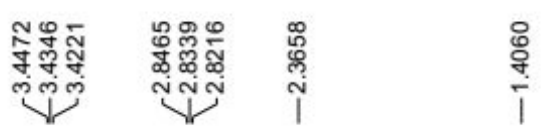
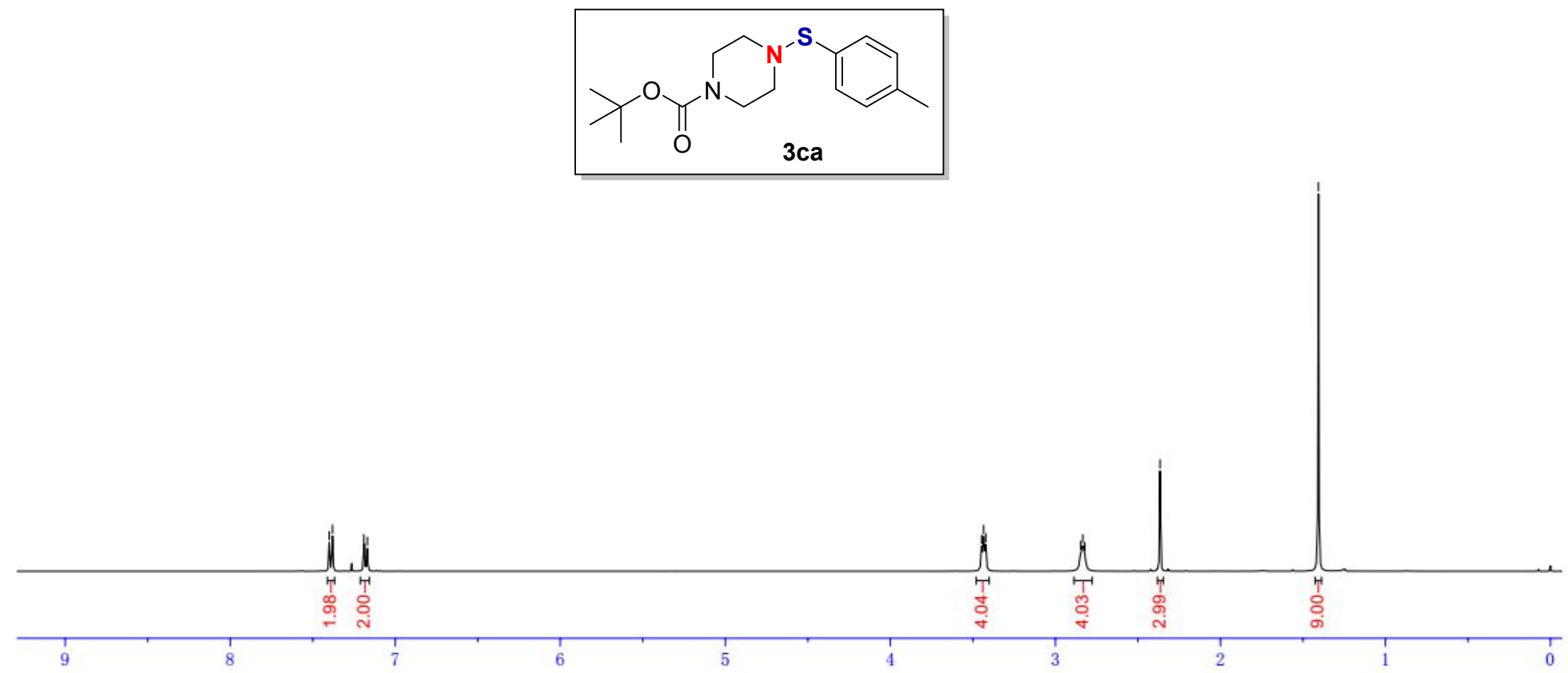


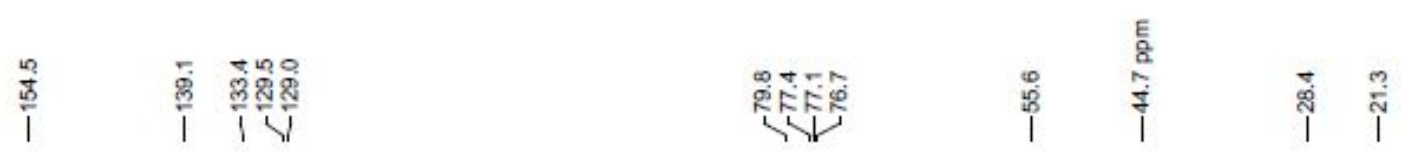
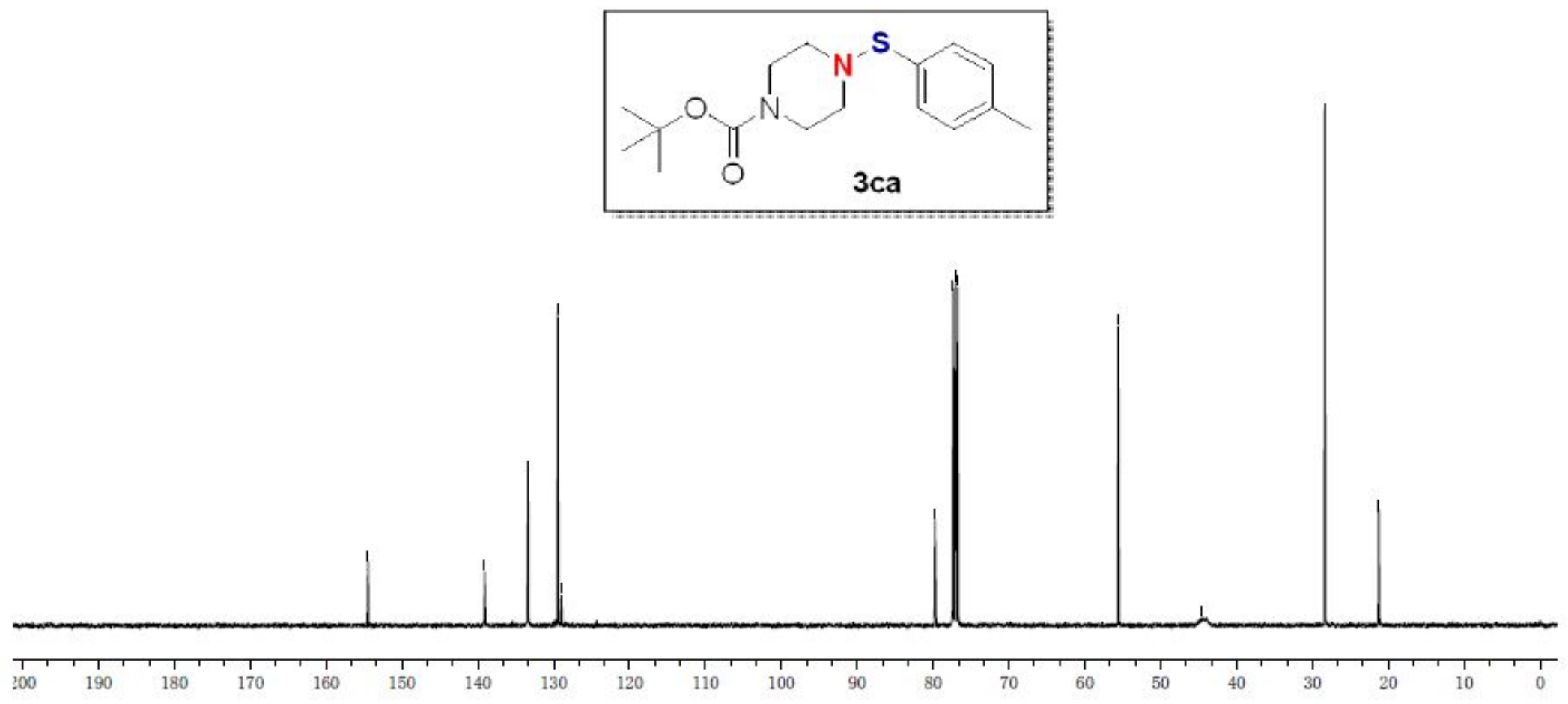
LSP-X190225-1HNMR

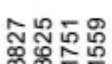

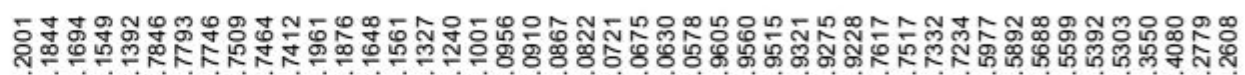

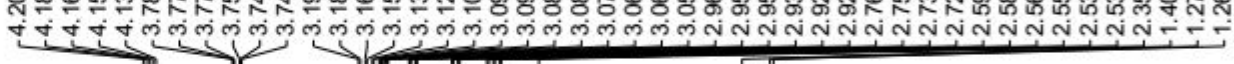

岤
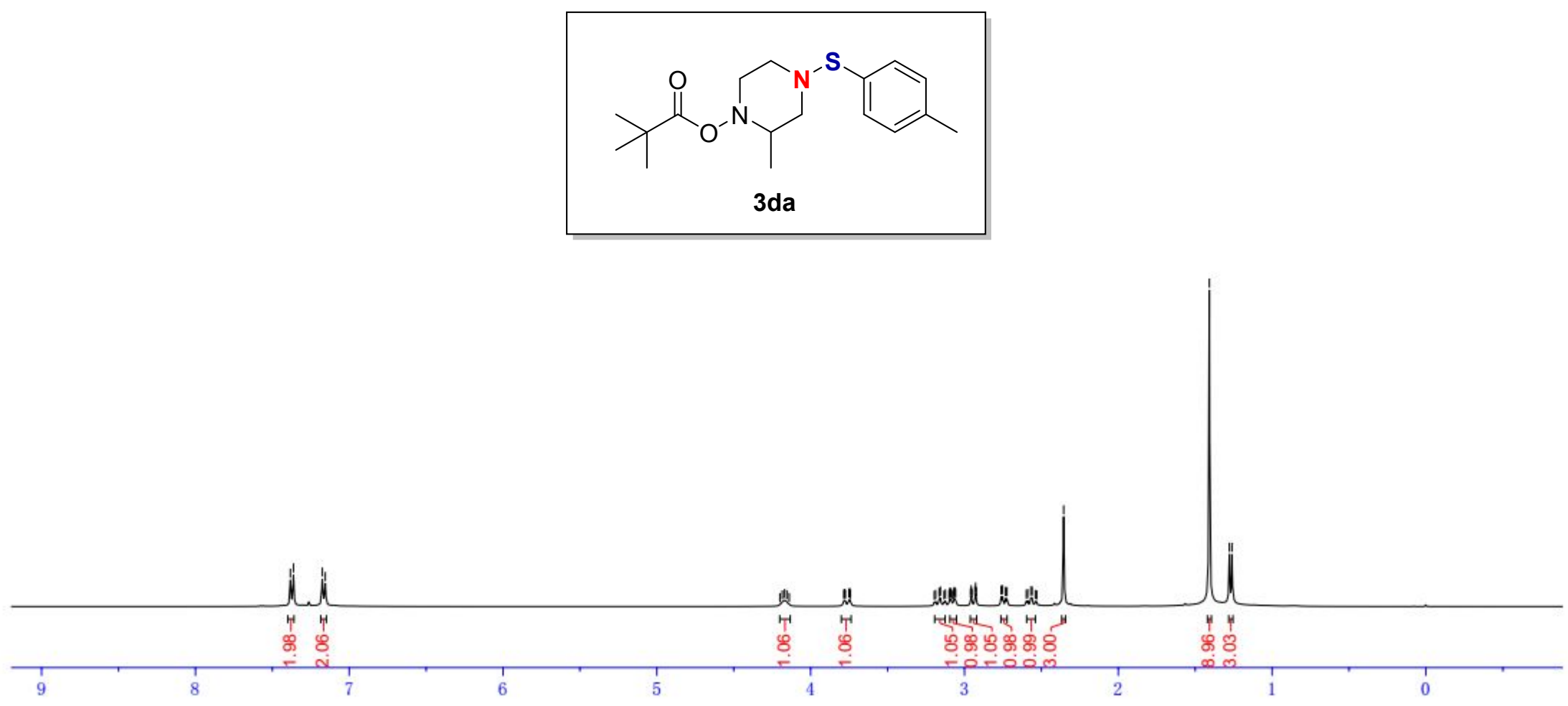


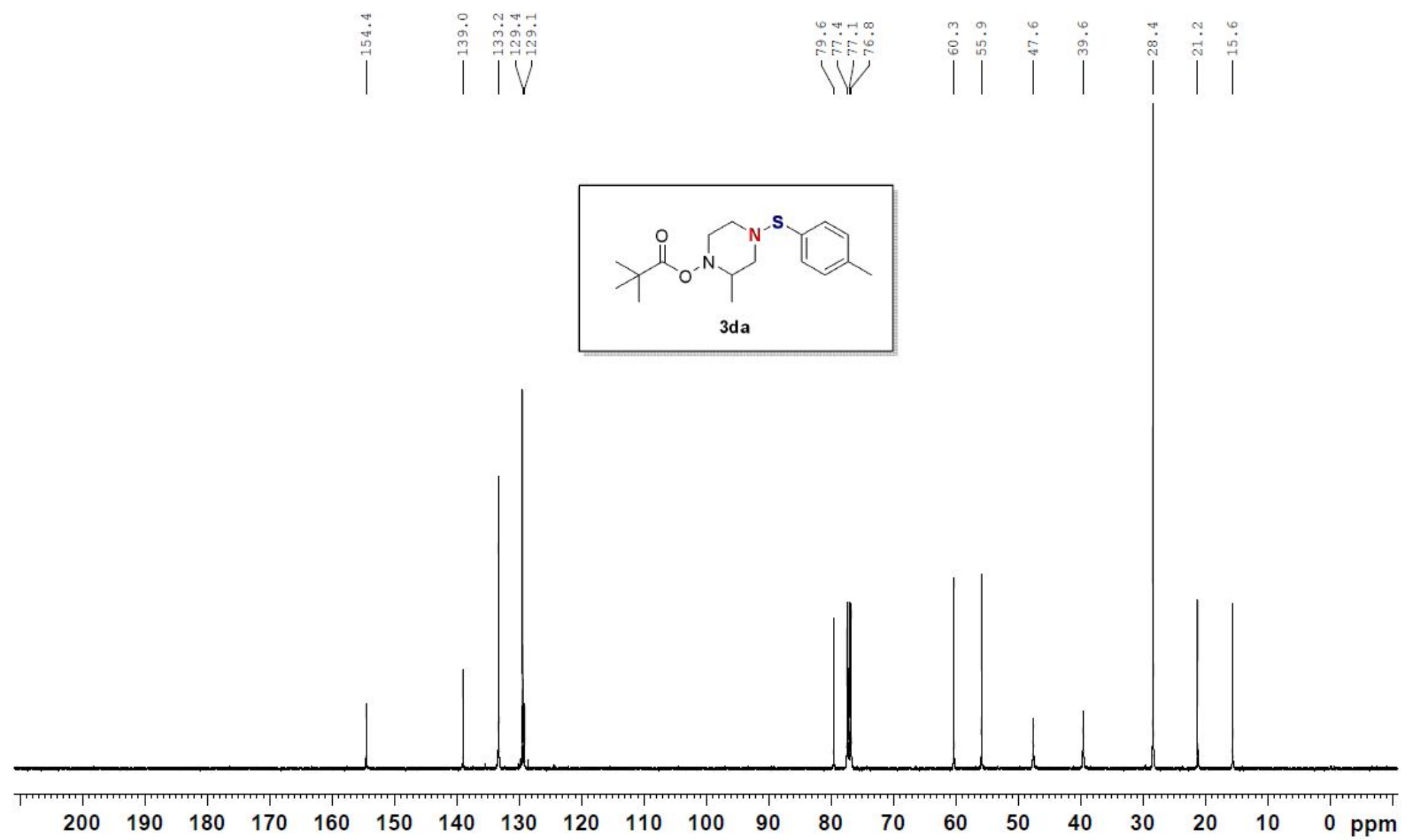


LSP-X190121-2HNMR
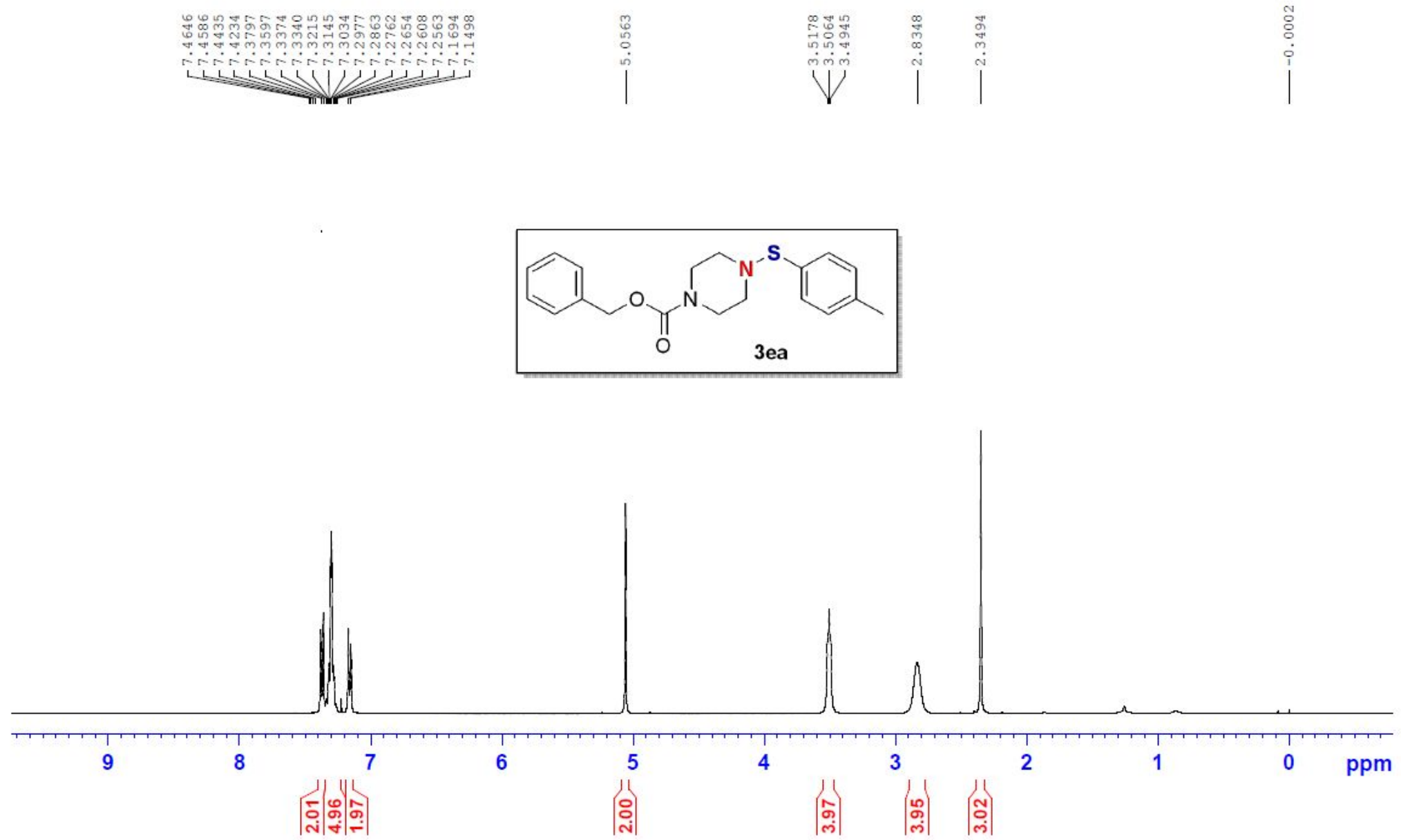
LSP-X190121-2CNMR
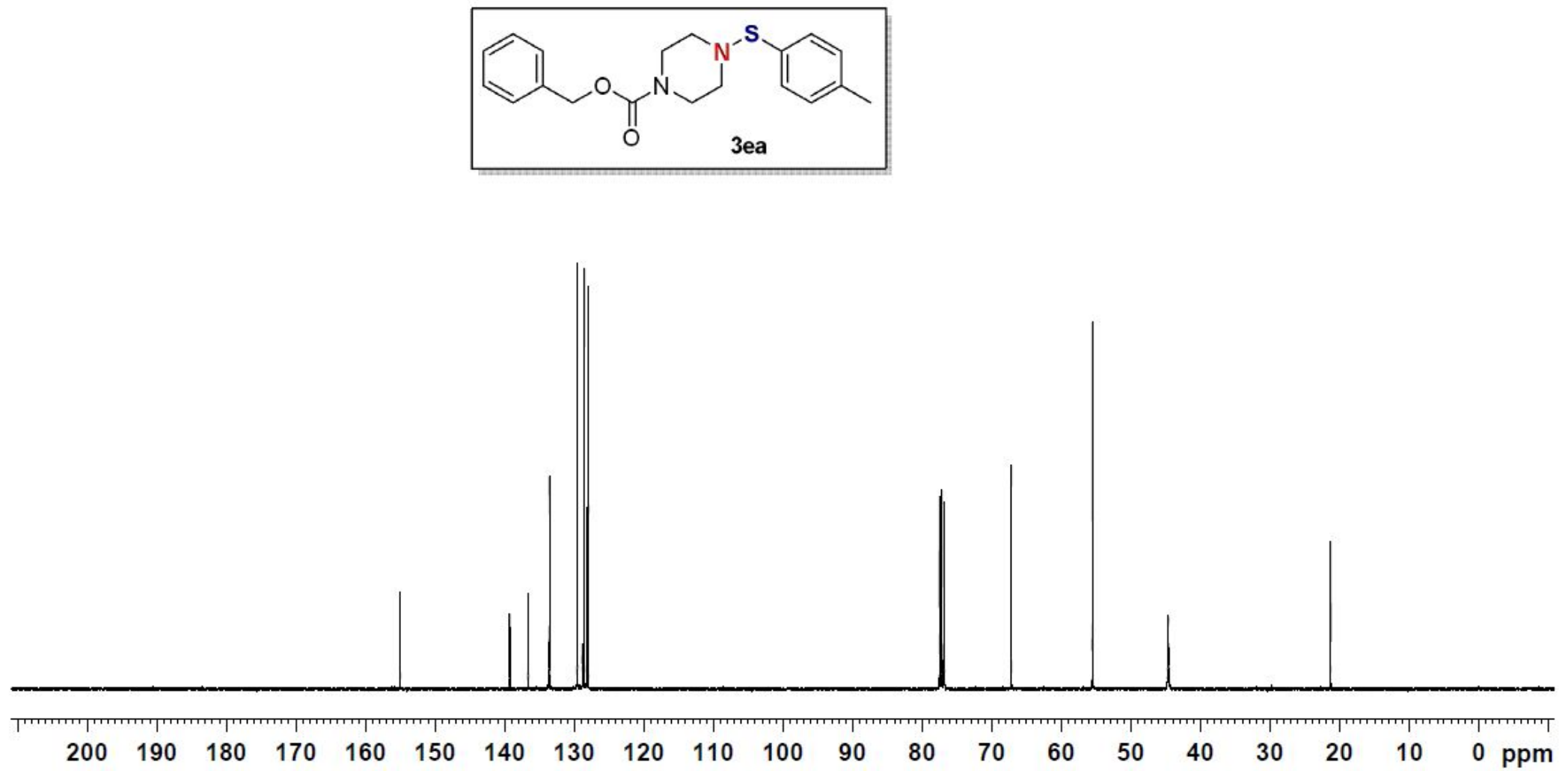

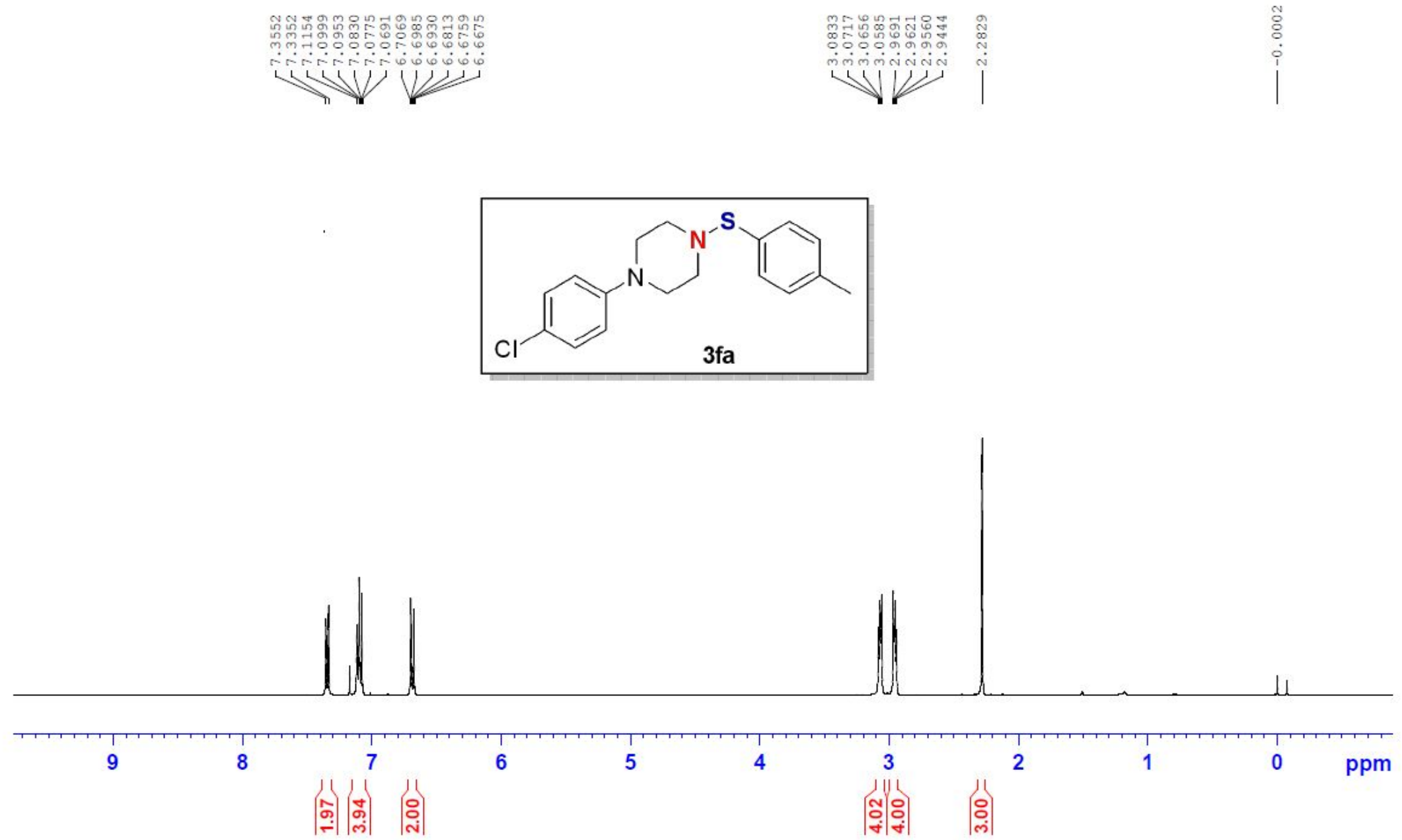

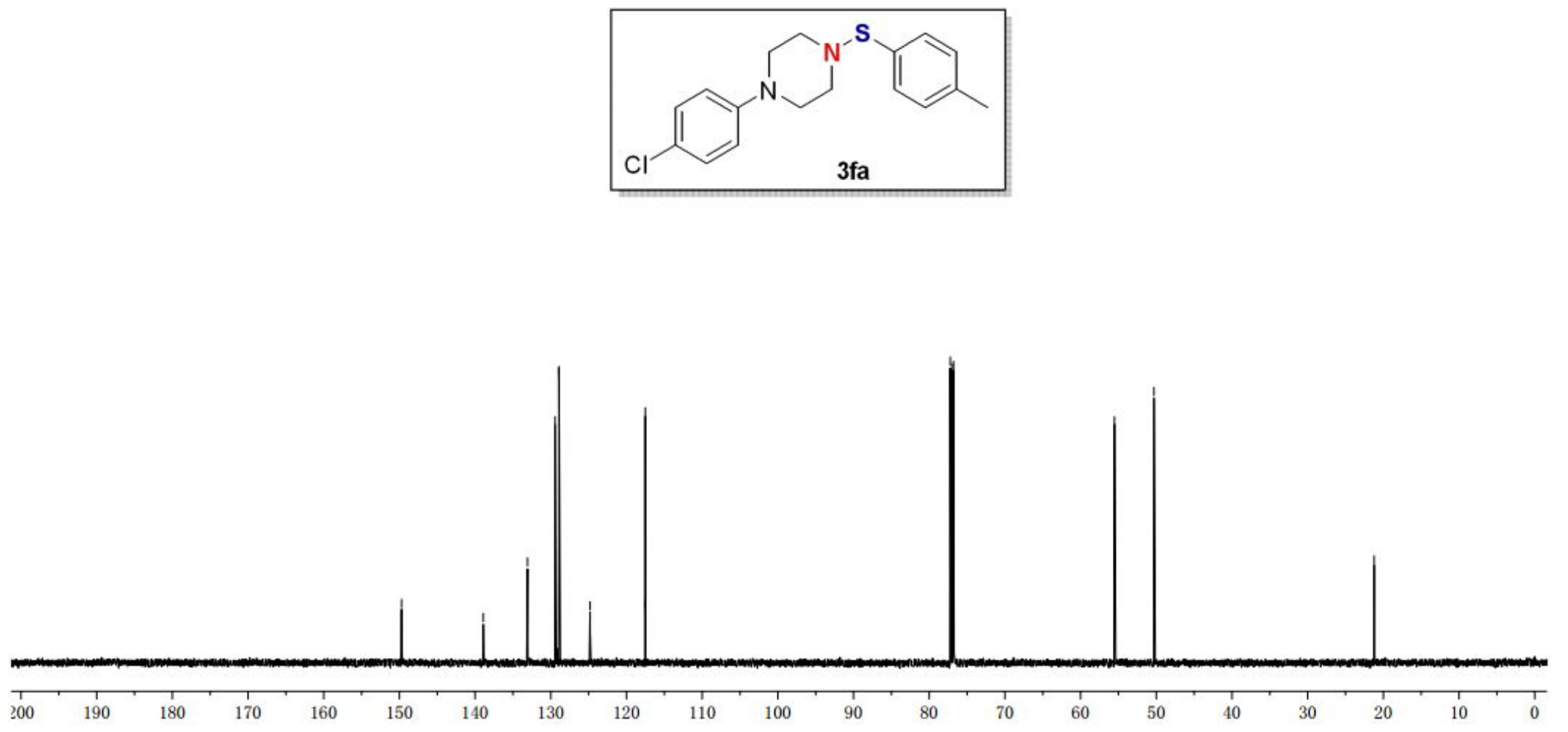
LSP-X190123-3HNMR

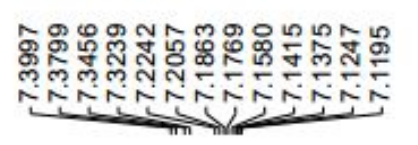

$\frac{\hat{8}}{i}$

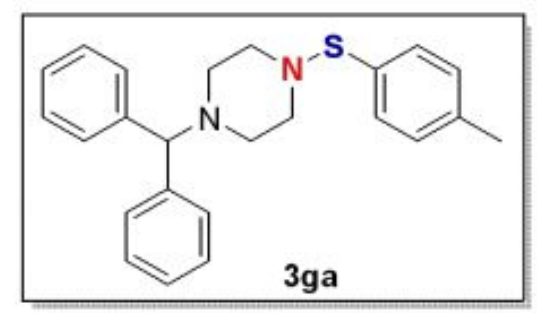

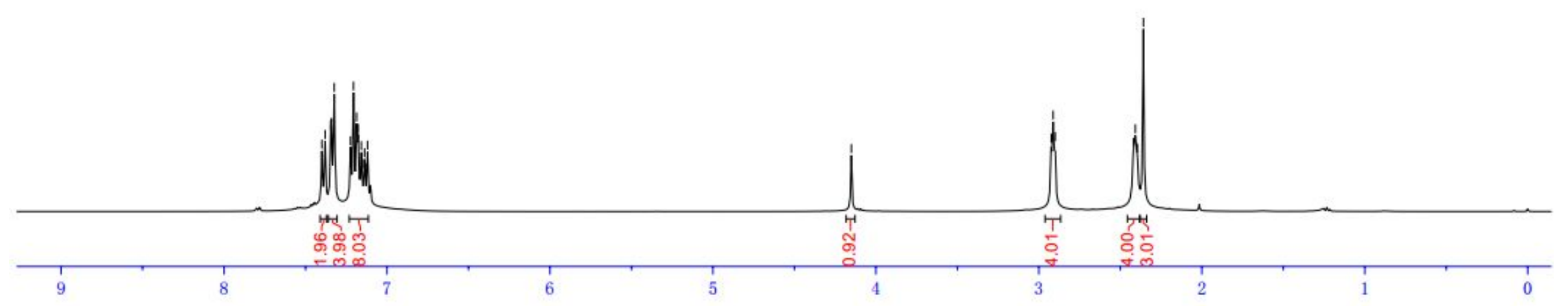


LSP-X190123-3CNMR
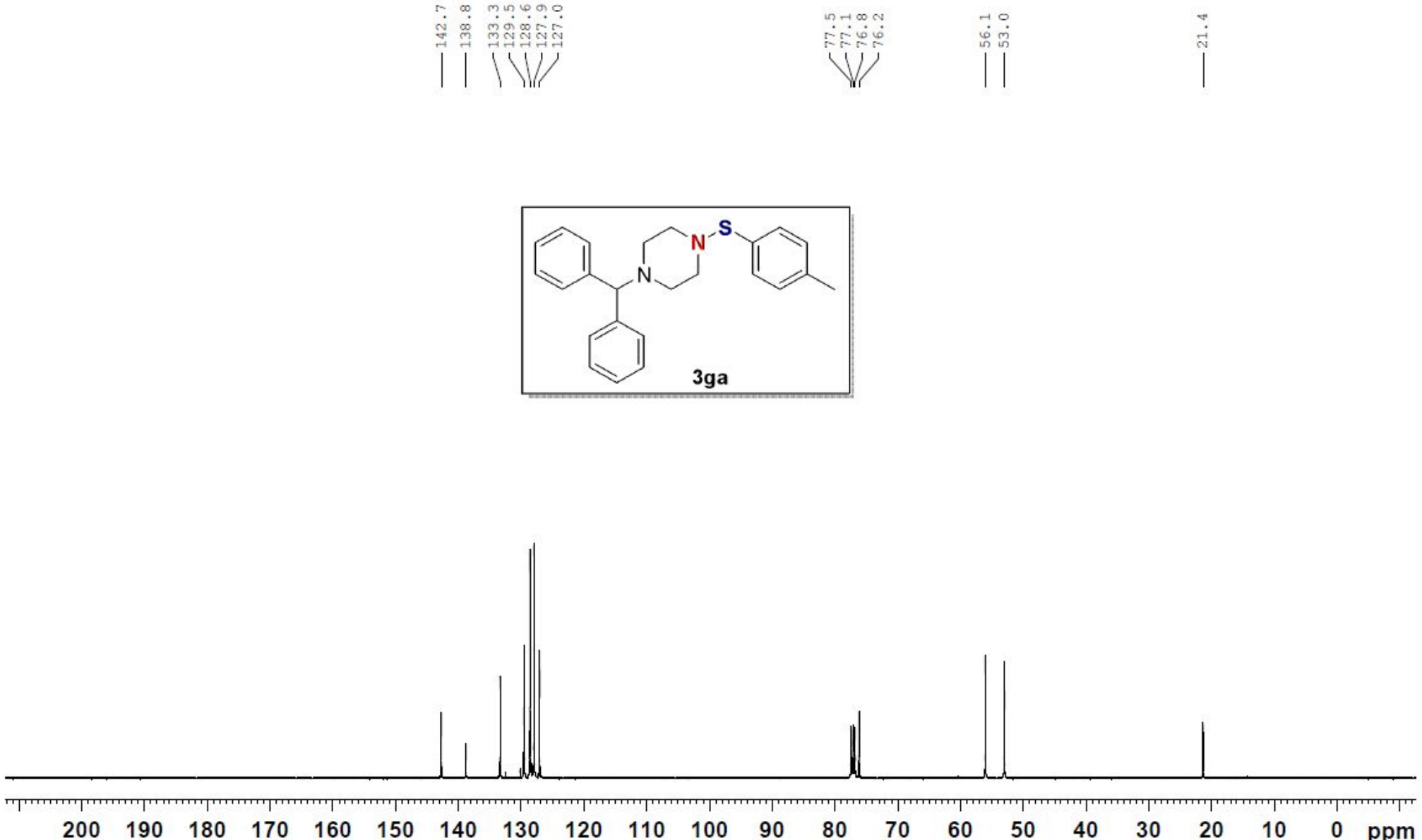

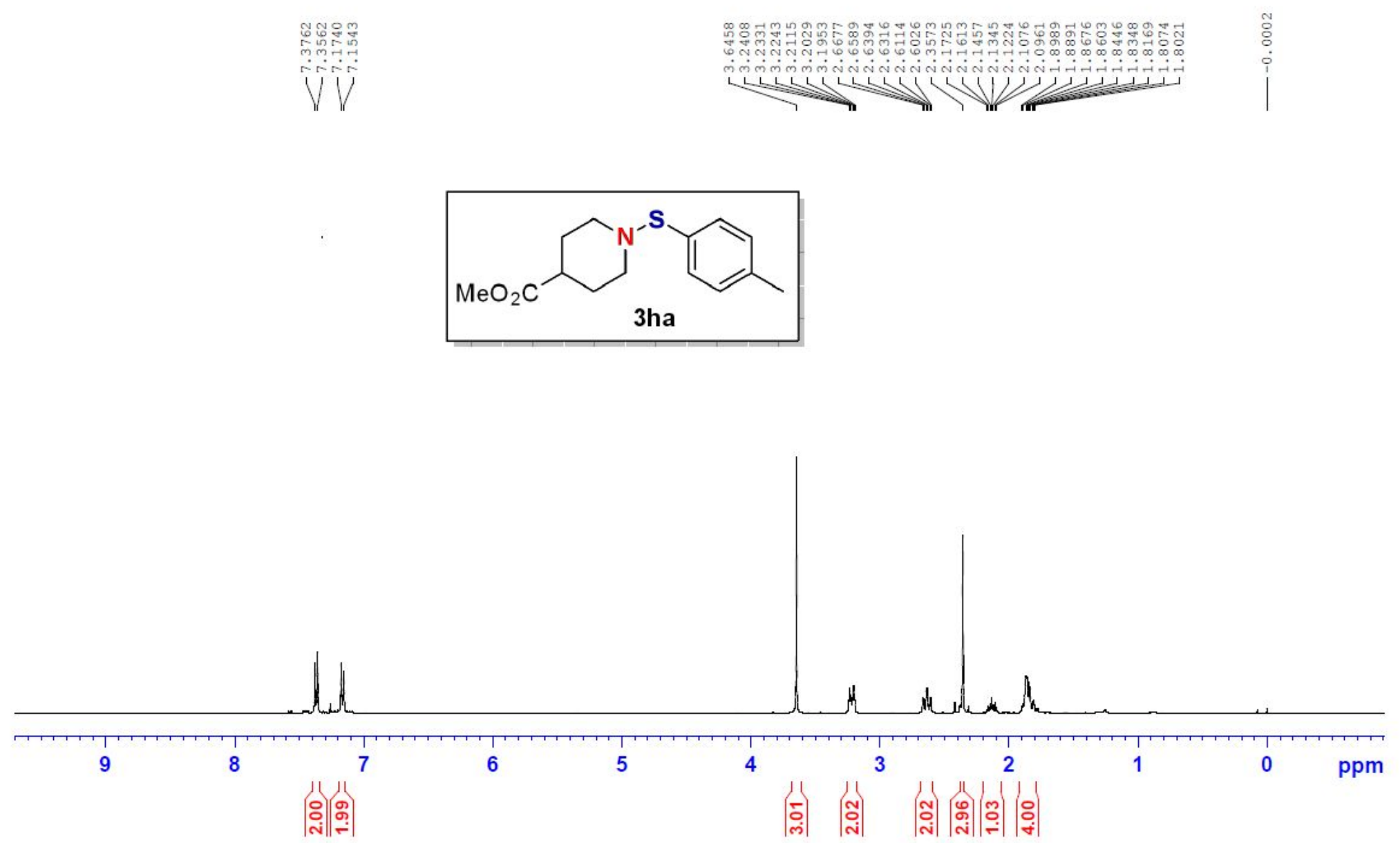


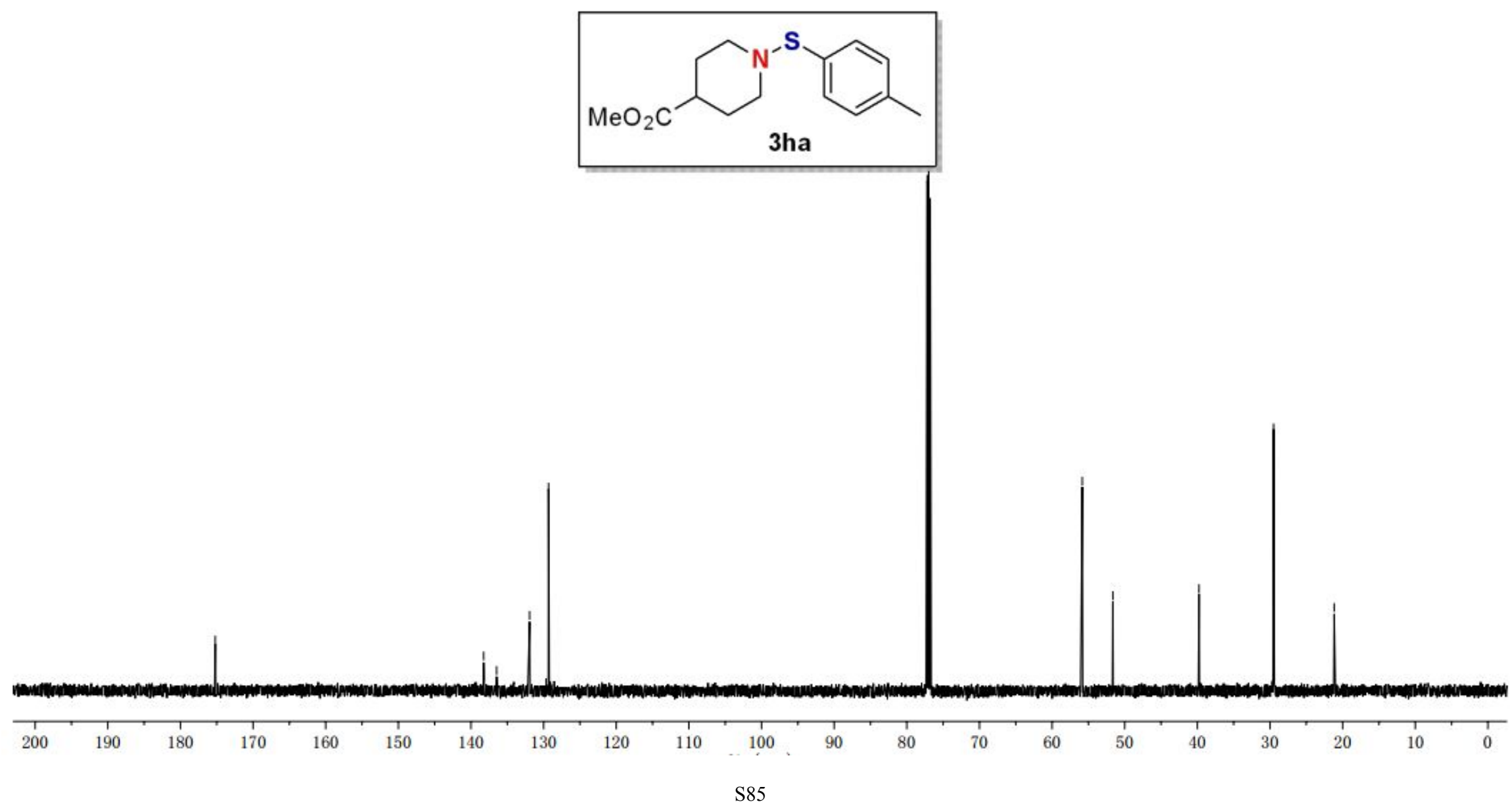




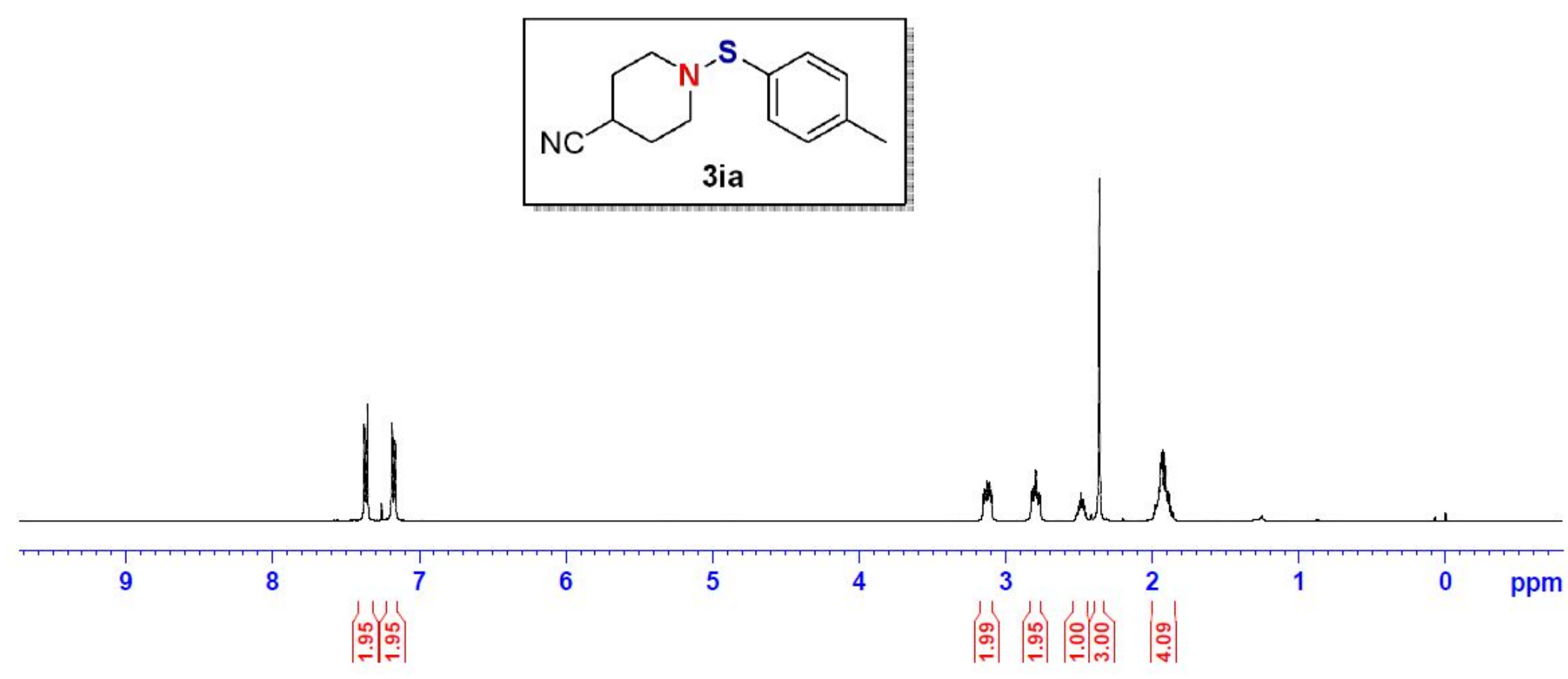


LSP-X190107-5C NMR

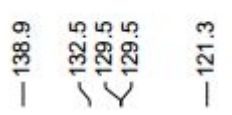

等昌

范

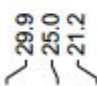
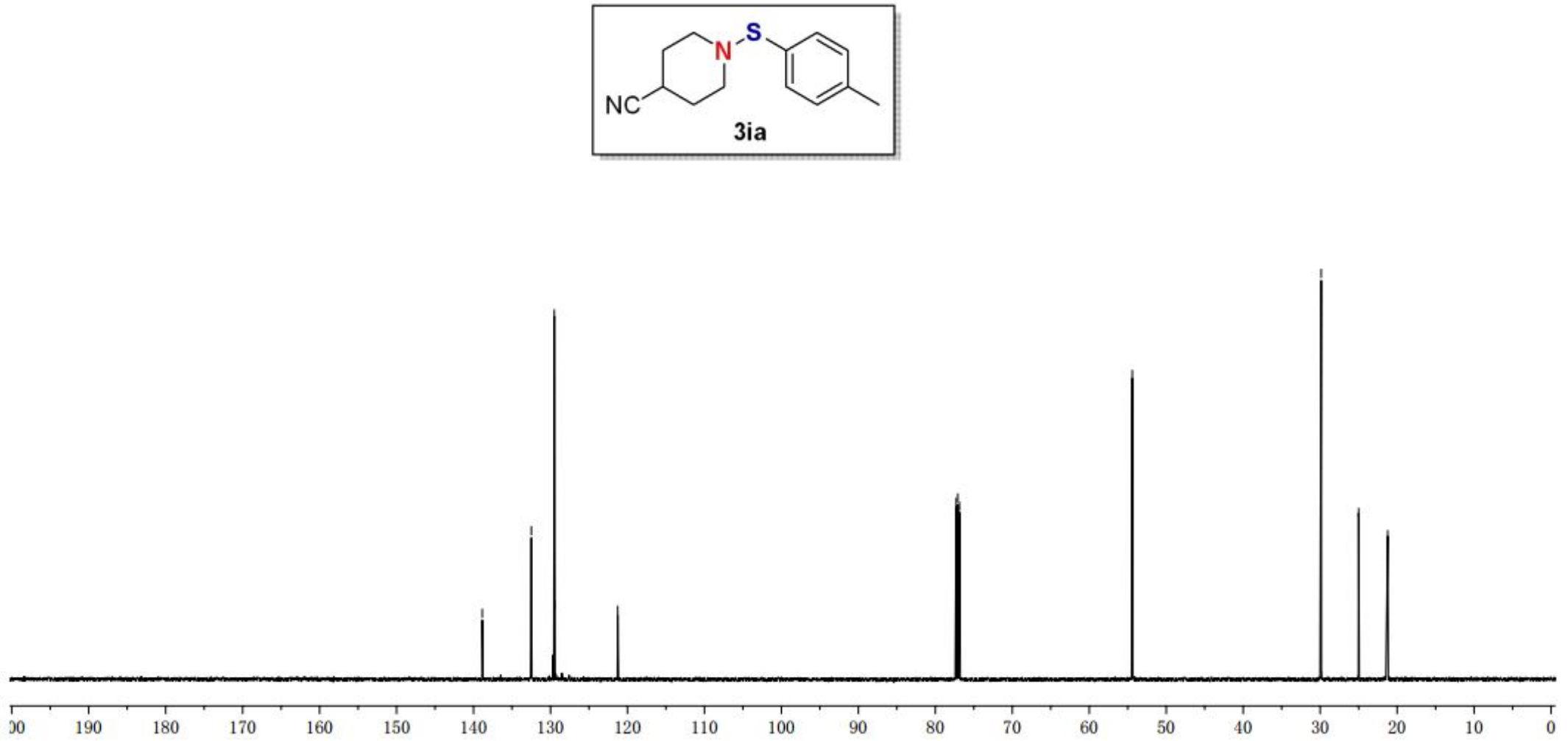
LSP-X190110-1HNMR
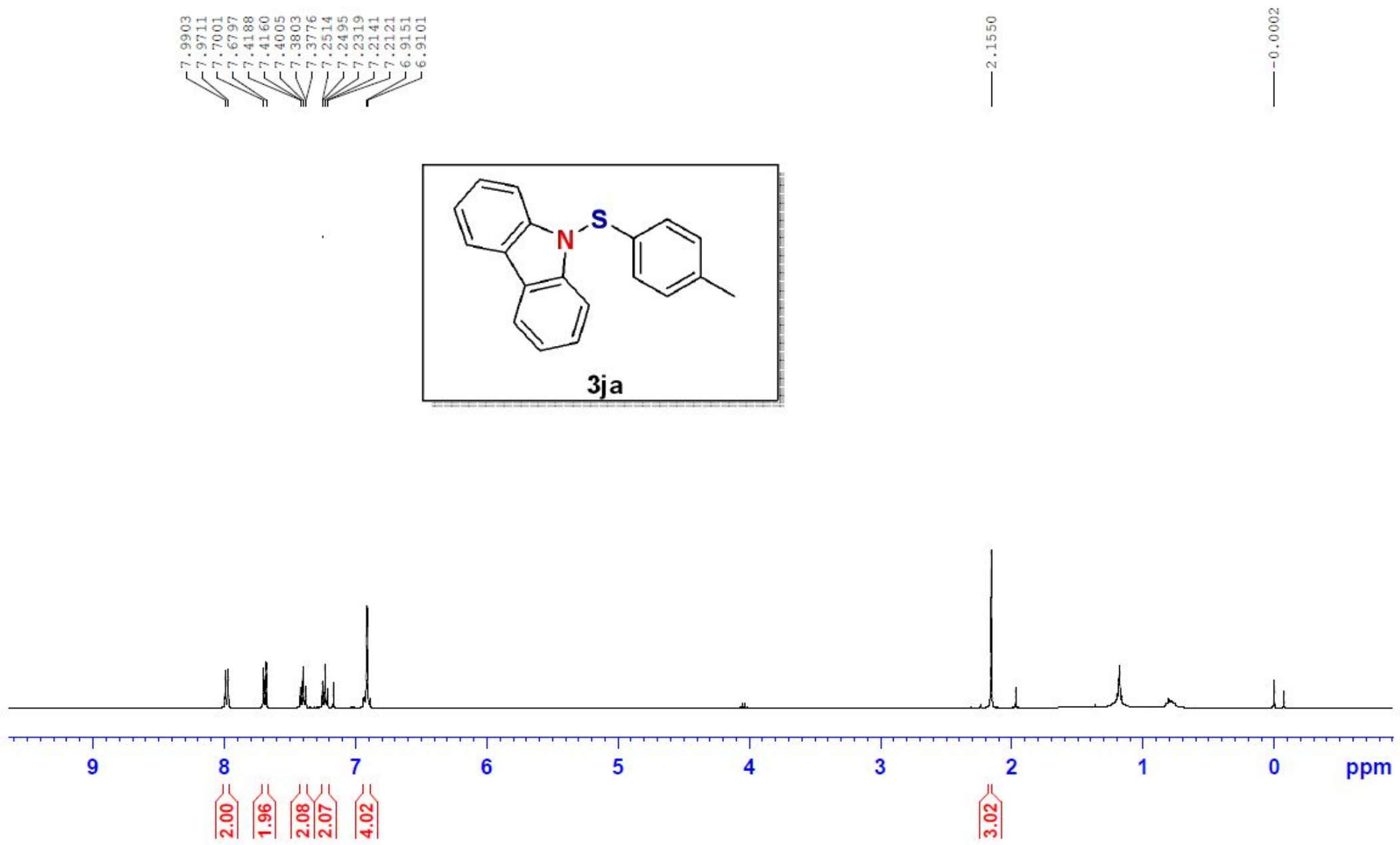
LSP-X190110-1CNMR
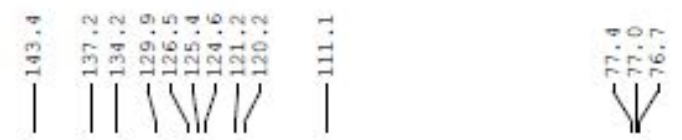

1
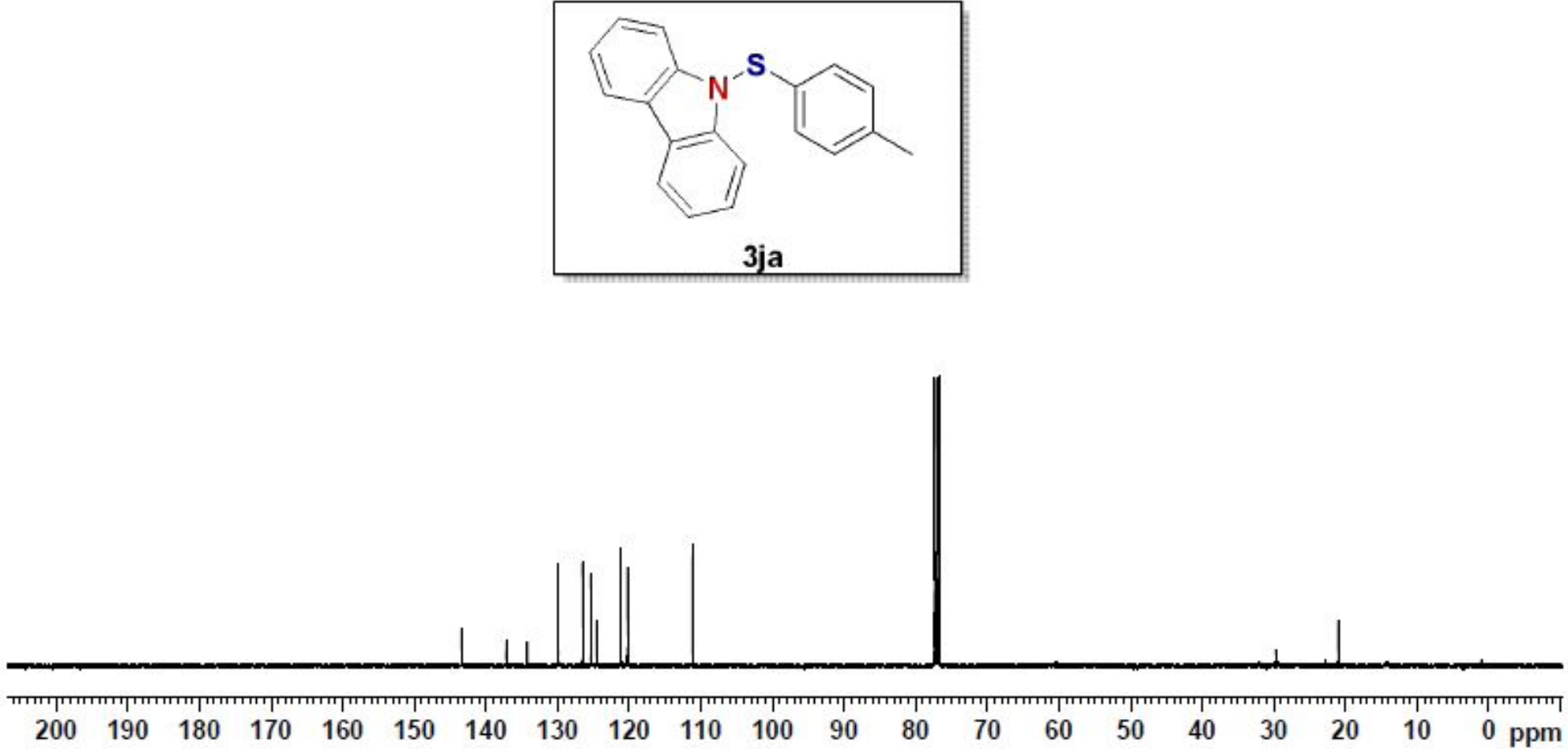
LSP-X190109-2HNMR
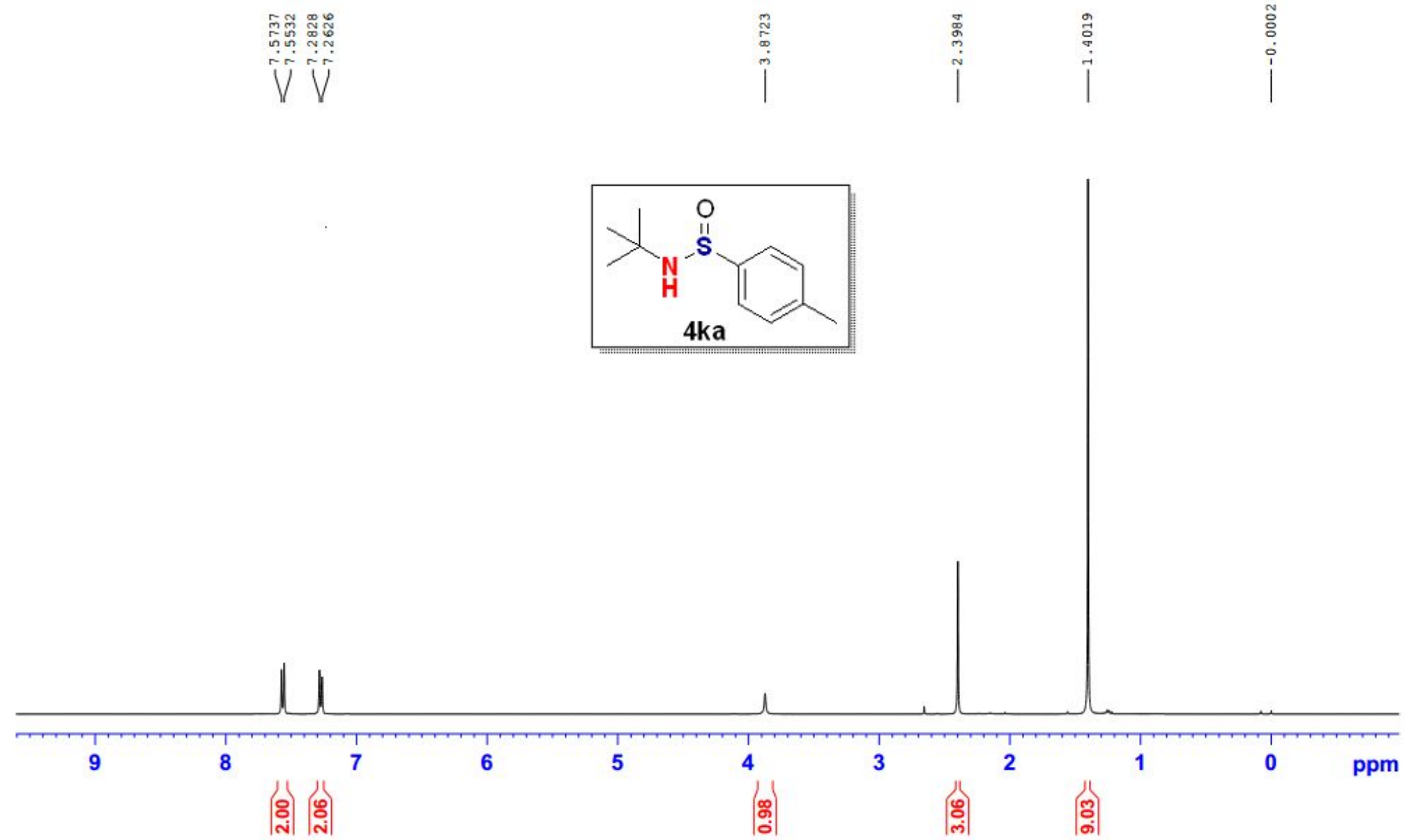


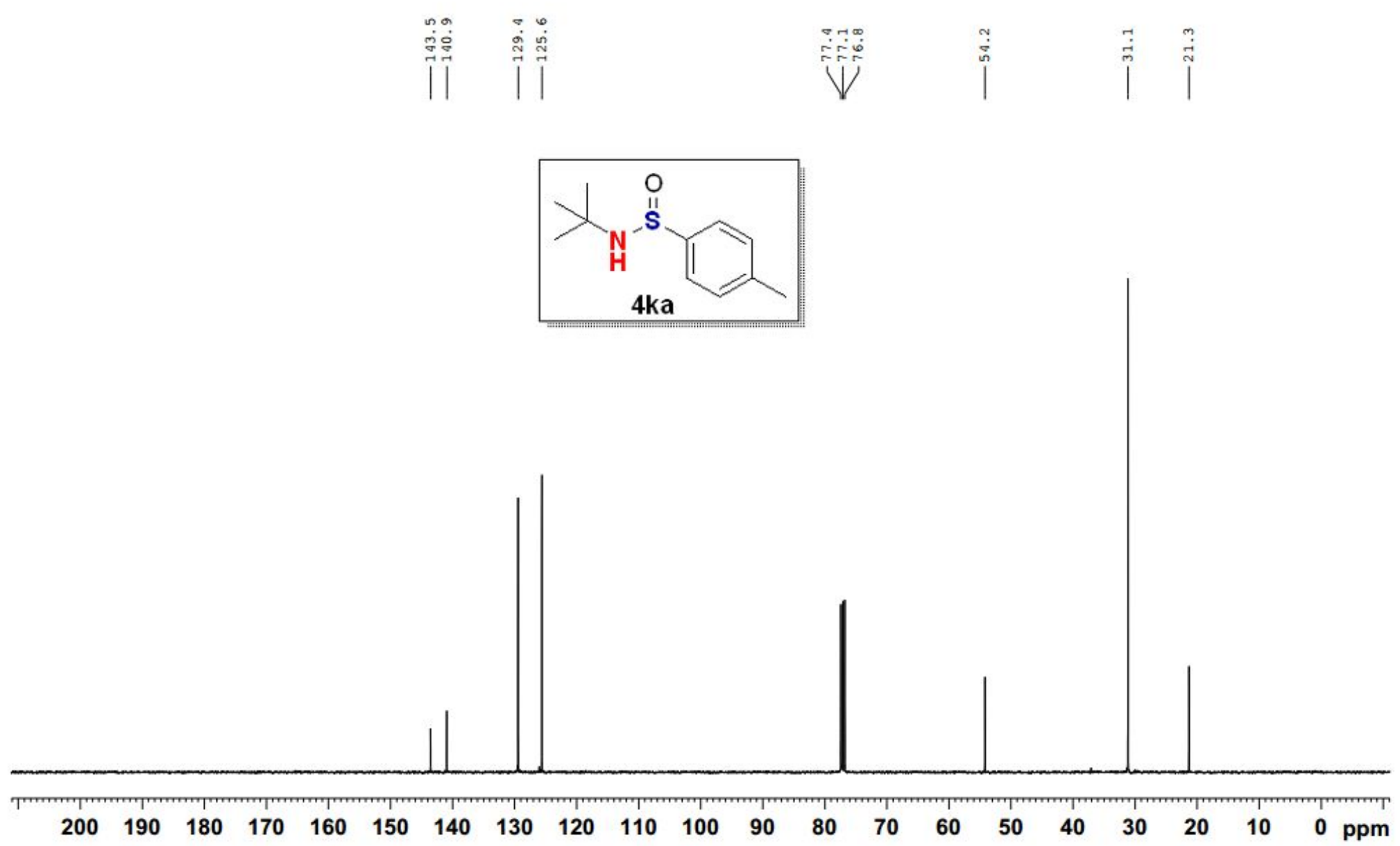


LSP-X180903-14HNMR

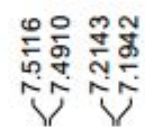

\section{1}
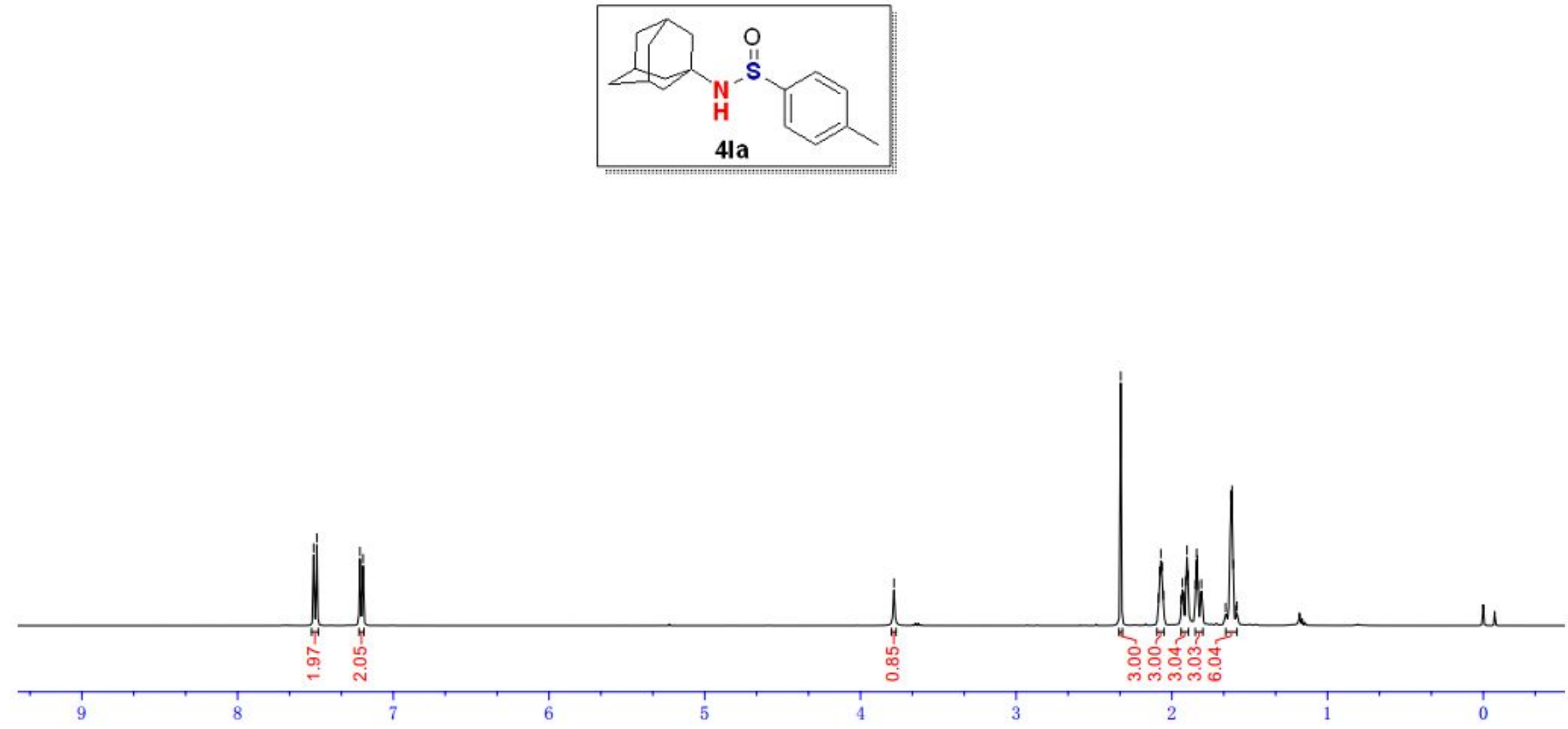
LSP-X180903-14CNMR
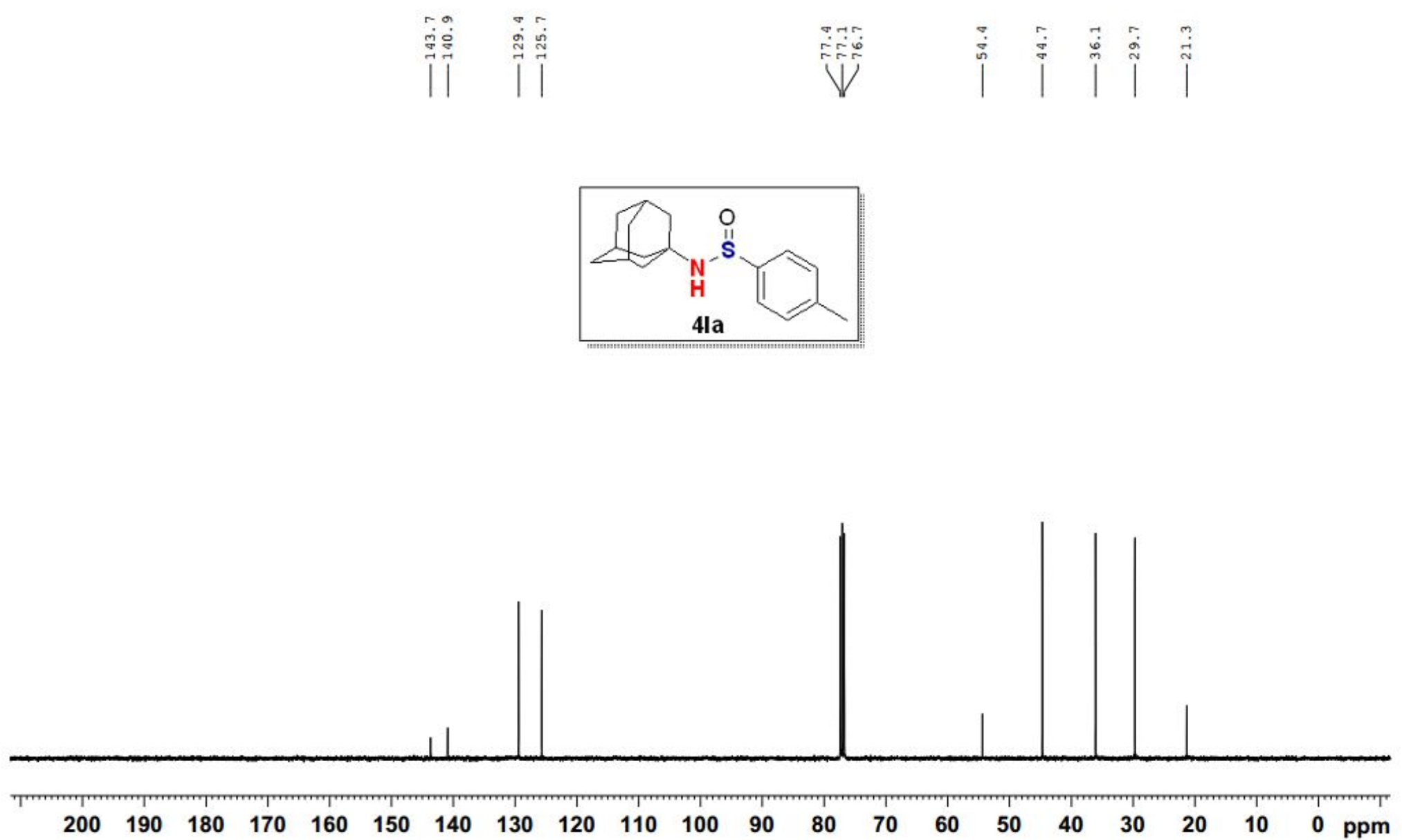
LSP-X190319-2HNMR
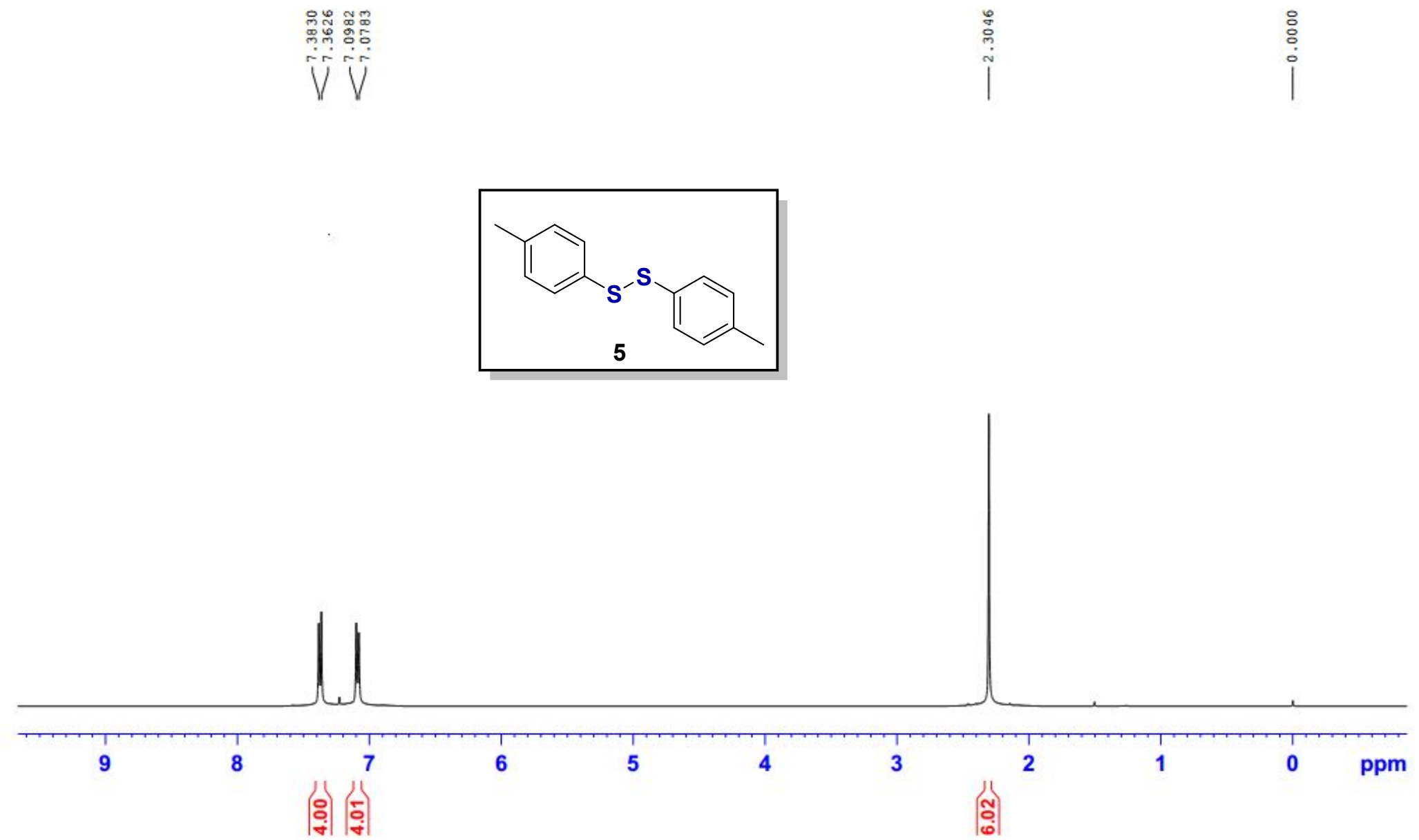
LSP-X190319-2CNMR

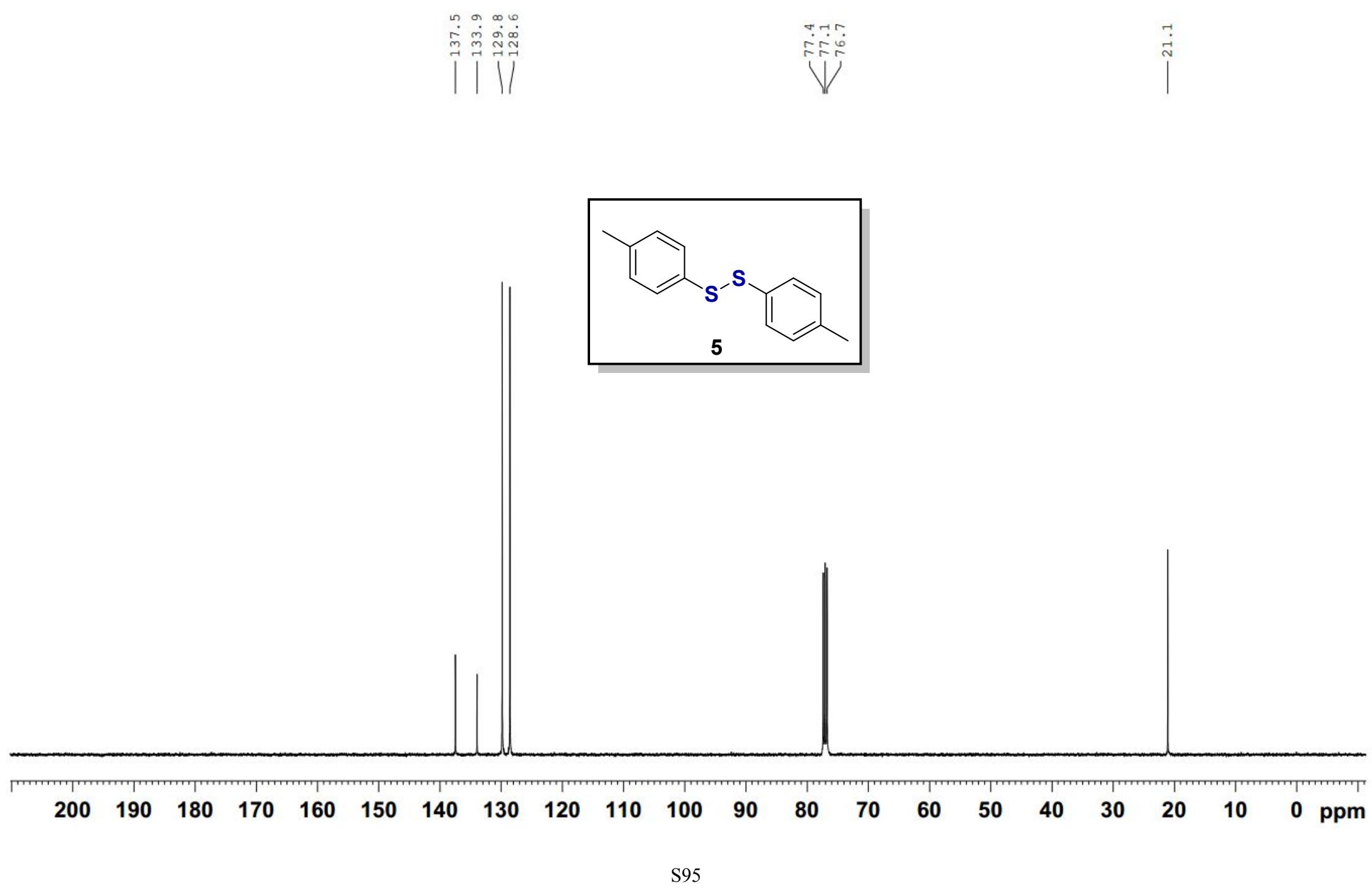


LSP-X190702-1HNMR
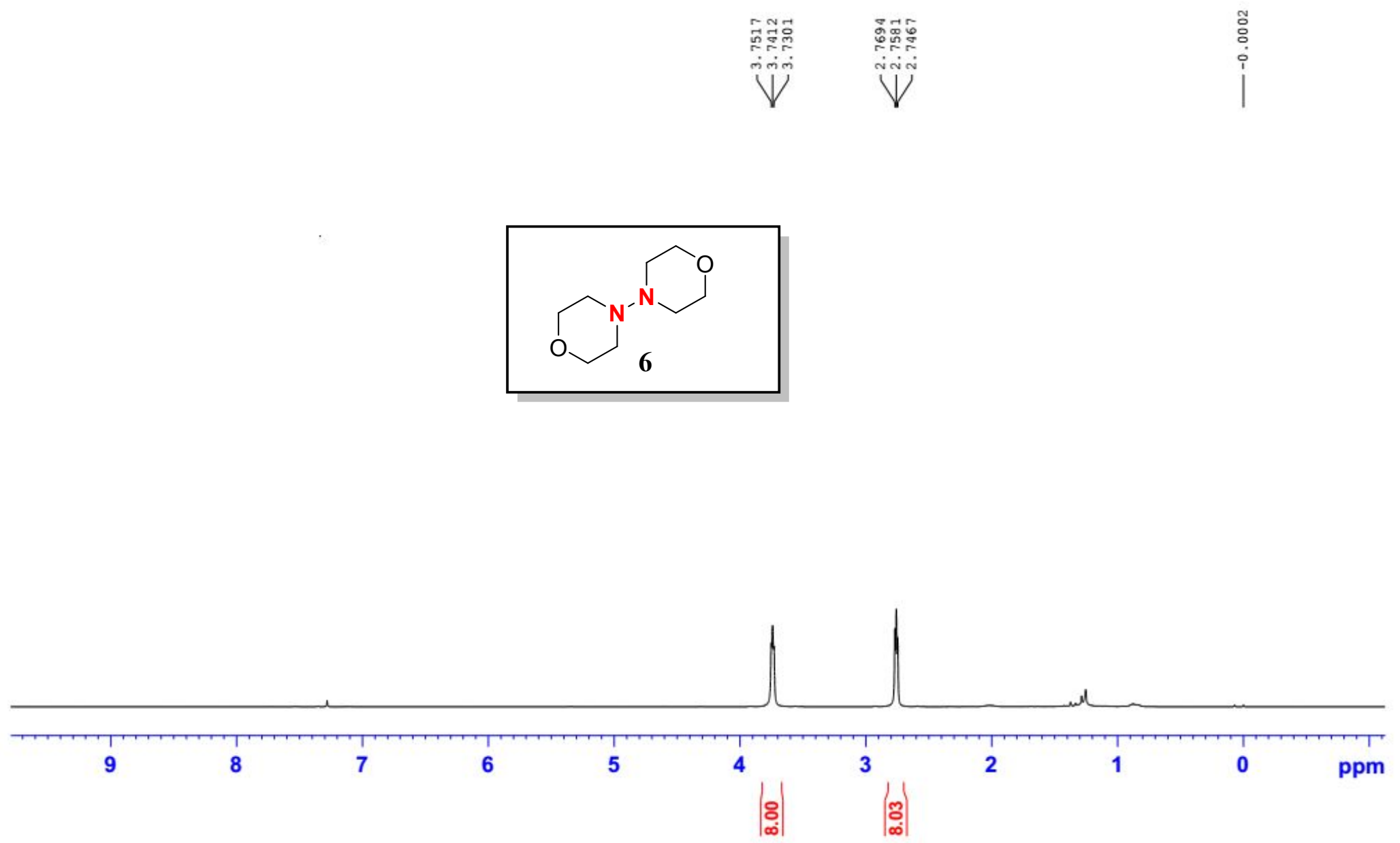

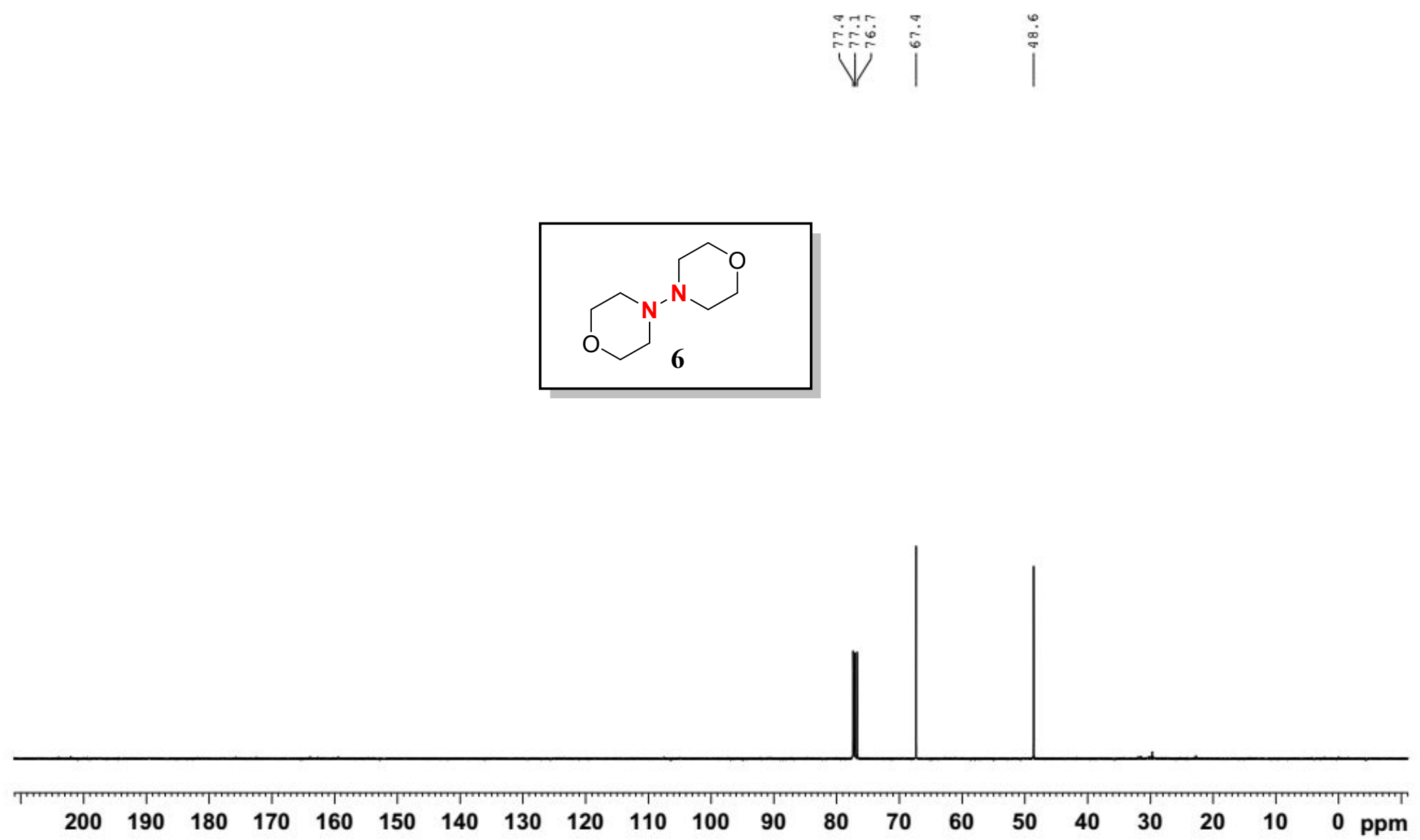


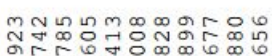

ن

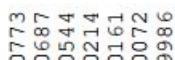

קंminimin

$\stackrel{\circ}{\circ}$
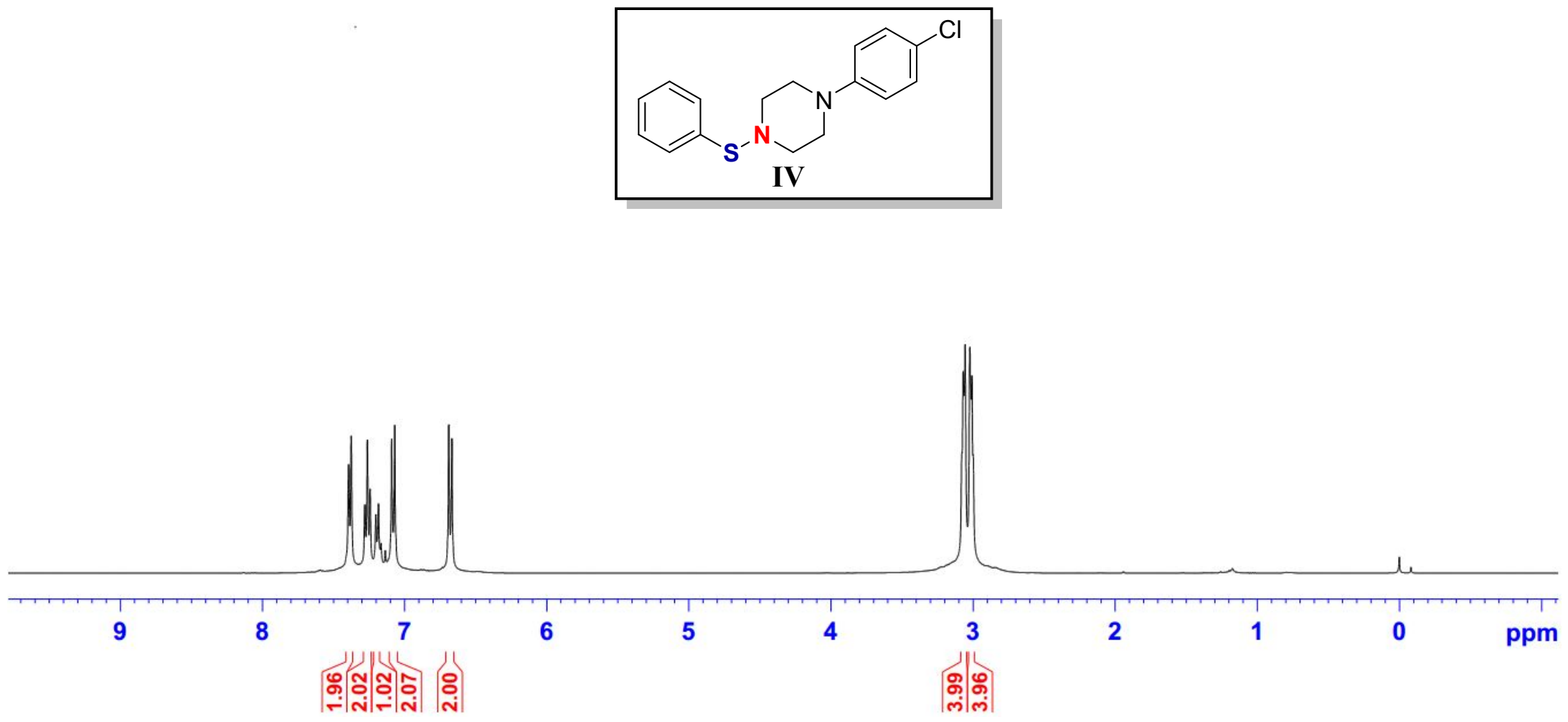
LSP-X190408-4CNMR
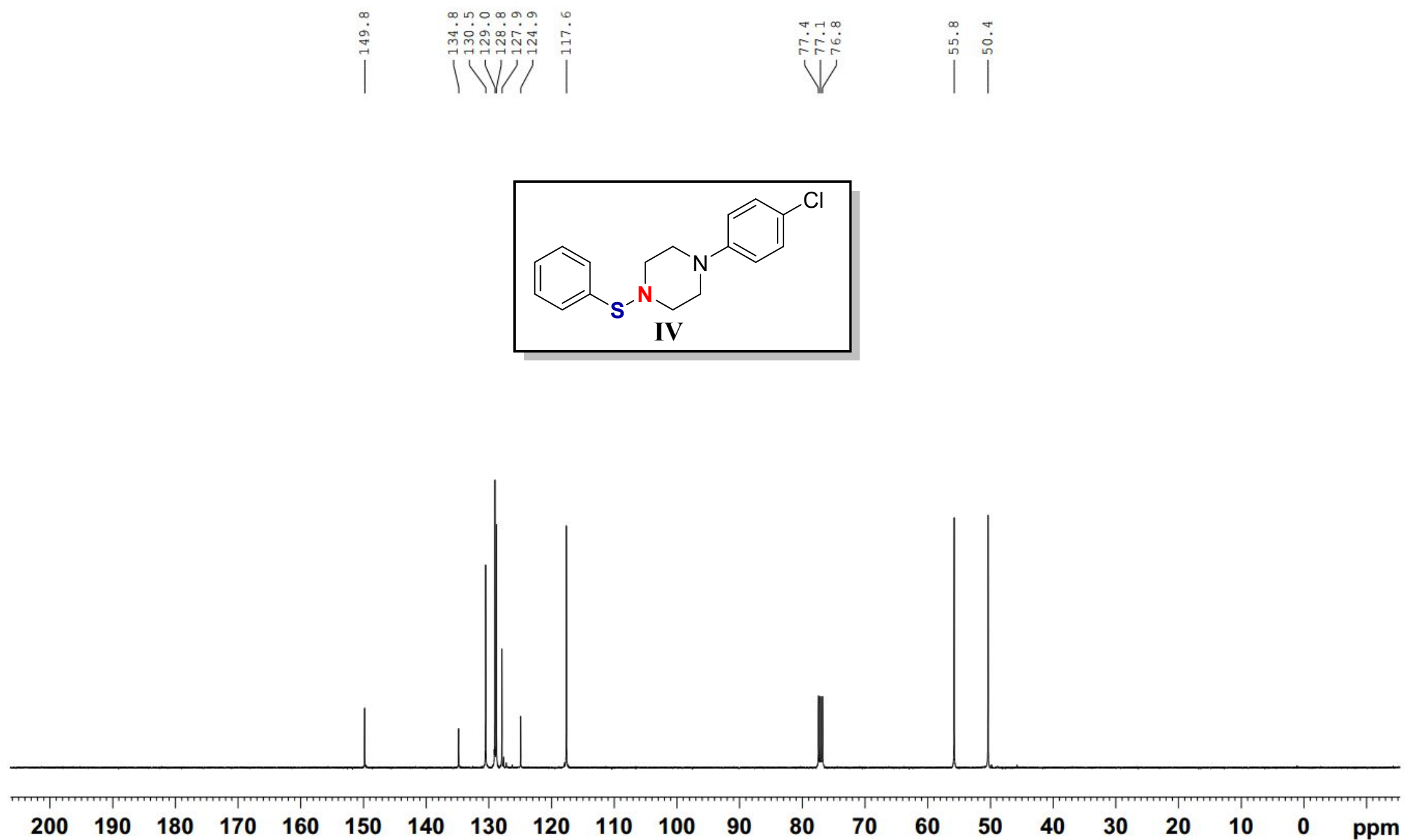